Master Thesis

Software Engineering

Thesis no: MSE-2010:11

May 2010

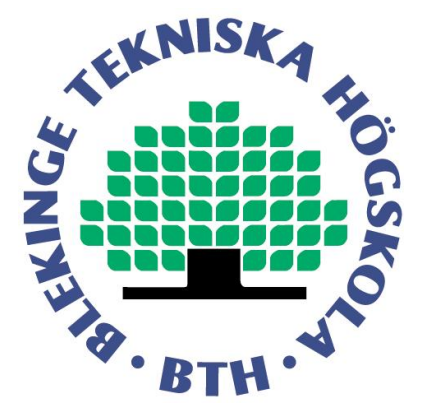

\title{
Towards innovation measurement in software industry
}

Nauman bin Ali and Henry Edison

School of Computing

Box 520

SE 37225 Ronneby

Sweden 
This thesis is submitted to the School of Computing at Blekinge Institute of Technology in partial fulfilment of the requirements for the degree of Master of Science in Software Engineering. The thesis is equivalent to $2 \times 20$ weeks of full time studies.

\section{Contact Information:}

Authors:

Nauman bin Ali

E-mail: nauman.ali@gmail.com

\section{Henry Edison}

E-mail: henry.sitorus@gmail.com

University advisor:

Dr. Richard Torkar

School of Computing

Blekinge Institute of Technology

Box 520

SE 37225 Ronneby

Sweden

Internet : www.bth.se/com

Phone : +46 457385000

Fax : +46 45727125 


\begin{abstract}
Context: In today's highly competitive business environment, shortened product and technology life-cycles, it is critical for software industry to continuously innovate. To help an organisation to achieve this goal, a better understanding and control of the activities and determinants of innovation is required. This can be achieved through innovation measurement initiative which assesses innovation capability, output and performance.

Objective: This study explores definitions of innovation, innovation measurement frameworks, key elements of innovation and metrics that have been proposed in literature and used in industry. The degree of empirical validation and context of studies was also investigated. It also elicited the perception of innovation, its importance, challenges and state of practice of innovation measurement in software industry.

Methods: In this study, a systematic literature review, followed by online questionnaire and face-to-face interviews were conducted. The systematic review used seven electronic databases, including Compendex, Inspec, IEEE Xplore, ACM Digital Library, and Business Source premier, Science Direct and Scopus. Studies were subject to preliminary, basic and advanced criteria to judge the relevance of papers. The online questionnaire targeted software industry practitioners with different roles and firm sizes. A total of 94 completed and usable responses from 68 unique firms were collected. Seven face-to-face semi-structured interviews were conducted with four industry practitioners and three academics.
\end{abstract}

Results: Based on the findings of literature review, interviews and questionnaire a comprehensive definition of innovation was identified which may be used in software industry. The metrics for evaluation of determinants, inputs, outputs and performance were aggregated and categorised. A conceptual model of the key measurable elements of innovation was constructed from the findings of the systematic review. The model was further refined after feedback from academia and industry through interviews.

Conclusions: The importance of innovation measurement is well recognised in both academia and industry. However, innovation measurement is not a common practice in industry. Some of the major reasons are lack of available metrics and data collection mechanisms to measure innovation. The organisations which do measure innovation use only a few metrics that do not cover the entire spectrum of innovation. This is partly because of the lack of consistent definition of innovation in industry. Moreover, there is a lack of empirical validation of the metrics and determinants of innovation. Although there is some static validations, full scale industry trials are currently missing. For software industry, a unique challenge is development of alternate measures since some of the existing metrics are inapplicable in this context. The conceptual model constructed in this study is one step towards identifying measurable key aspects of innovation to understanding the innovation capability and performance of software firms. 


\section{Acknowledgments}

We would like to express our gratitude to our supervisor Dr. Richard Torkar for guidance and support throughout this thesis project. We are grateful to both industry contacts and academics at BTH who spared time for insightful interviews and discussions. We are also thankful to all the industry practitioners who participated in the survey conducted during the course of this thesis project. We are thankful to Binish and Osman for reviewing and proof reading the report. Lastly we are thankful to our friends and family for their support and patience throughout the last two years and especially the last three months. It would not have been possible without all of you. 


\section{TABLE OF CONTENTS}

$1 \quad$ Introduction $\quad 8$

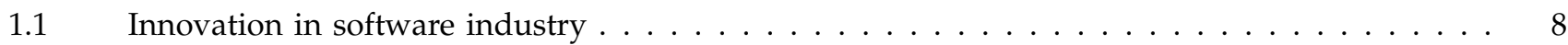

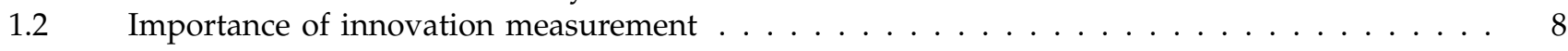

2 Background 9

3 Related Work 9

4 Research methodology 10

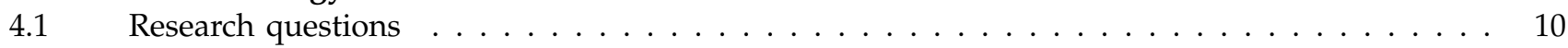

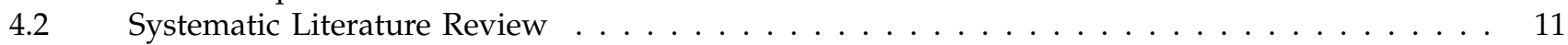

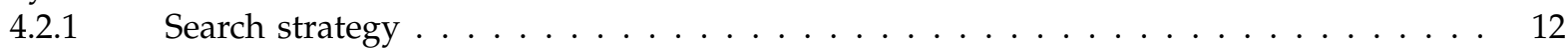

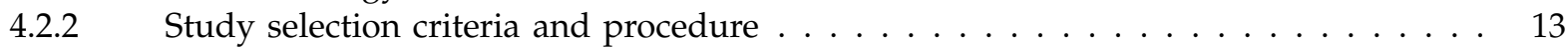

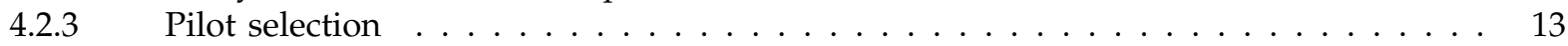

4.2.4 Study quality assessment criteria . . . . . . . . . . . . . . . . . . . . . . . . . . . . . . . . . . .

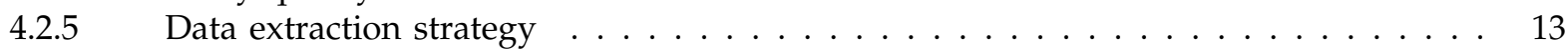

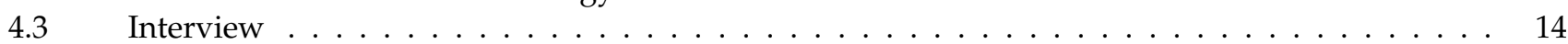

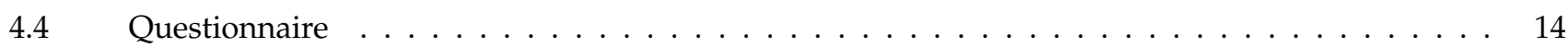

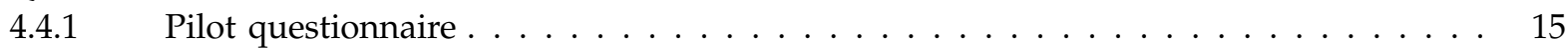

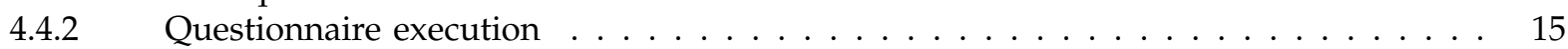

$5 \quad$ Results 15

5.1 Systematic Literature Review . . . . . . . . . . . . . . . . . . . . . . . 15

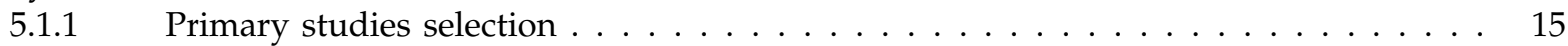

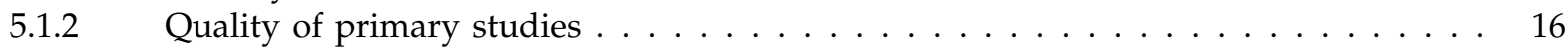

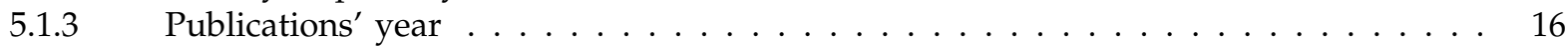

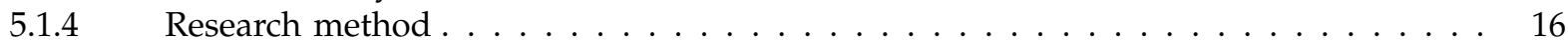

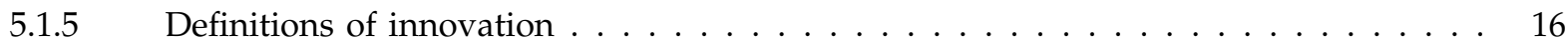

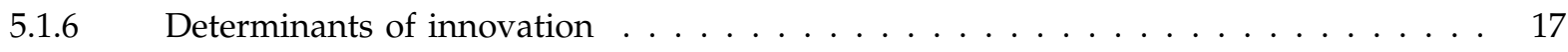

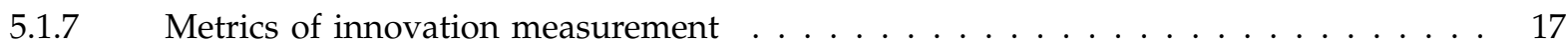

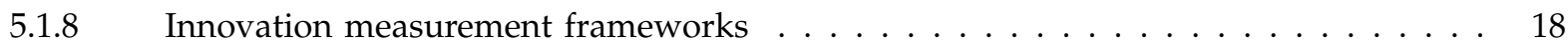

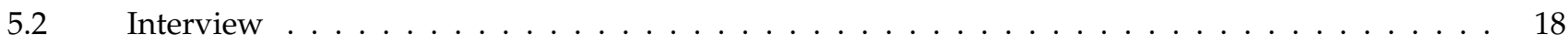

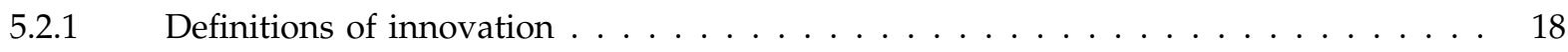

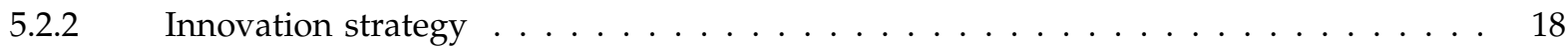

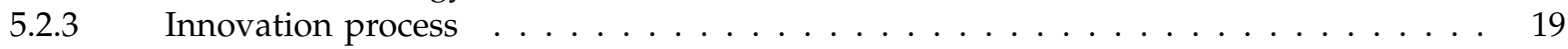

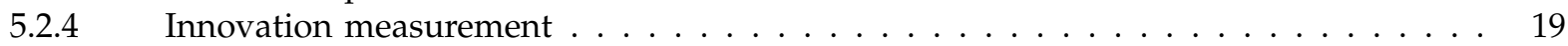

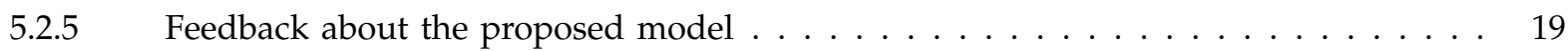

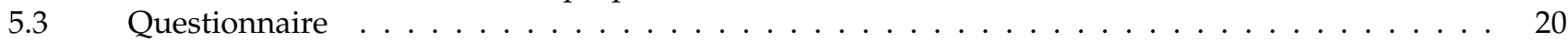

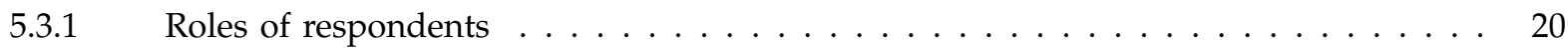

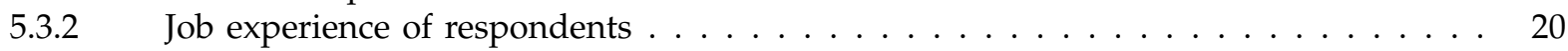

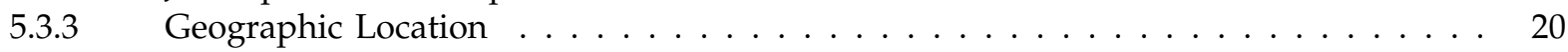

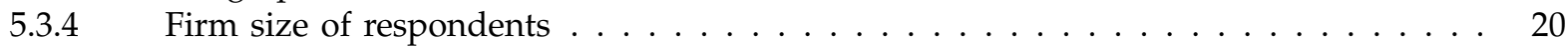

6 Analysis 21

6.1 RQ1 State of the art of innovation measurement . . . . . . . . . . . . . . . . 21

6.1.1 RQ1.1 Definitions of innovation reported in literature . . . . . . . . . . . . 21

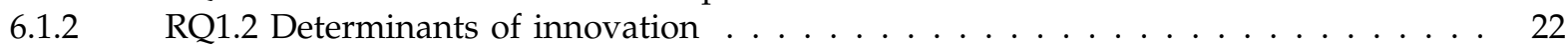

6.1.3 RQ1.3 Metrics for innovation measurement . . . . . . . . . . . . . . . . . . . . . . .

6.1.4 RQ1.4 Existing innovation measurement models . . . . . . . . . . . . . . 23

6.2 RQ2 State-of-the-practice in innovation measurement . . . . . . . . . . . . . . . . . 24

6.2.1 RQ2.1 Definitions of innovation . . . . . . . . . . . . . . . . . . 24

6.2.2 RQ2.2 Importance of innovation measurement . . . . . . . . . . . . . . . . . . . . . . . . . .

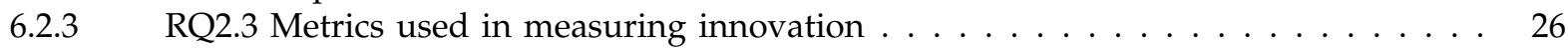

6.2.4 RQ2.4 Framework used for innovation measurement . . . . . . . . . . . . . . . . . . . .

6.2.5 RQ2.5 Challenges of innovation measurement . . . . . . . . . . . . . . 27 
Discussions

$7.1 \quad$ Definition of innovation for software industry $\ldots \ldots \ldots \ldots \ldots \ldots$

7.2 Importance of innovation measurement . . . . . . . . . . . . . . . . . . . . . . . . . . 29

7.3 Determinants of innovation in software industry . . . . . . . . . . . . . . . . . . . . . . . . . . 29

$7.4 \quad$ Challenges in measurement of innovation in software industry . . . . . . . . . . . . . . . . 29

7.4.1 Lack of a consistent definition of innovation . . . . . . . . . . . . . . . . . 29

7.4.2 Lack of metrics . . . . . . . . . . . . . . . . . . . . . . . . . . . . . . . 29

7.4.3 Lack of frameworks for innovation measurement . . . . . . . . . . . . . . . . . 29

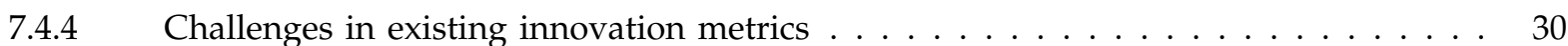

$8 \quad$ Proposed model

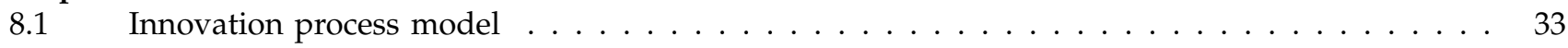

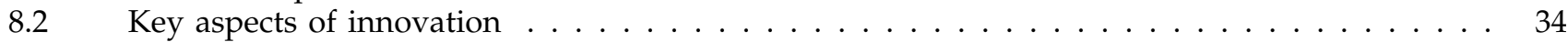

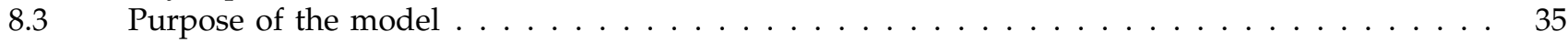

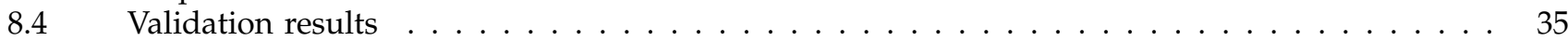

9 Validity Threats 36

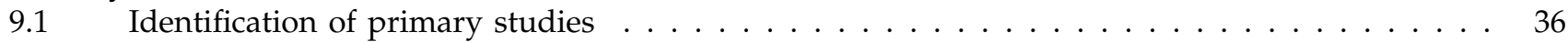

9.2 Primary studies selection and data extraction $\ldots \ldots \ldots \ldots \ldots \ldots \ldots \ldots \ldots \ldots$

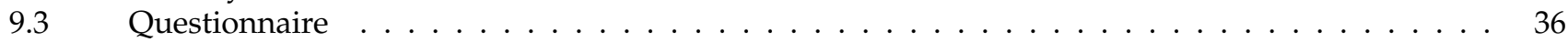

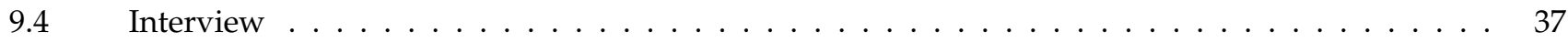

10 Conclusions \& Future work $\quad 38$

$\begin{array}{lr}\text { References } & 38\end{array}$

Appendix A: Search strings $\quad 43$

Appendix B: Definitions of innovation $\quad 45$

Appendix C: Determinants of innovation $\quad 47$

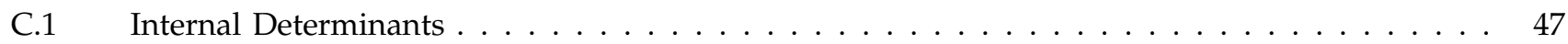

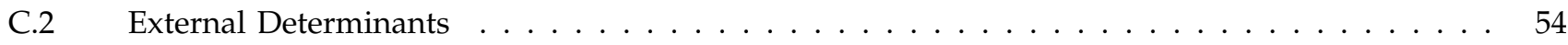

Appendix D: Determinants and innovation activities $\quad 55$

Appendix E: Metrics for innovation from software related studies $\quad 56$

Appendix F: Classification of metrics with innovation activities $\quad 57$

Appendix G: Classification of metrics for evaluation of innovation output and performance 59

Appendix H: Classification of metrics for evaluation of innovation inputs 61

Appendix I: Innovation measurement frameworks found in literature 62

Appendix J: Studies found in systematic review related to software 63

Appendix K: Interview questions $\quad 64$

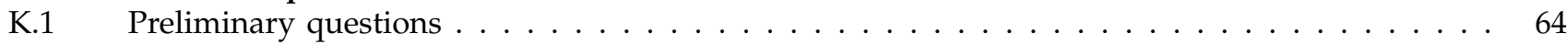

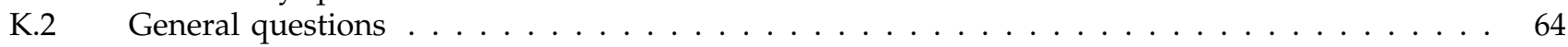

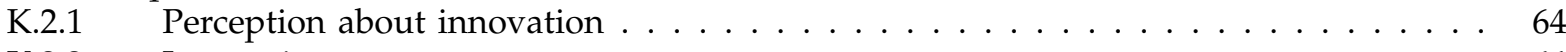

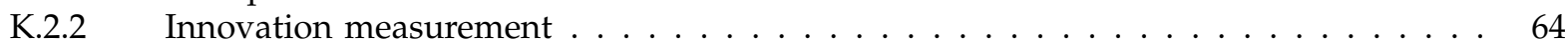

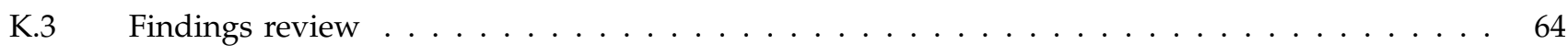

Appendix L: Background information of interviewees $\quad 65$

Appendix M: Questionnaire questions 66 


\section{LIST OF FIGURES}

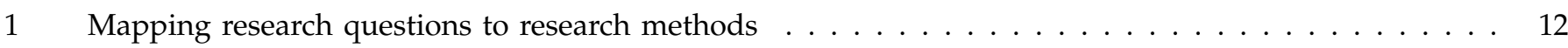

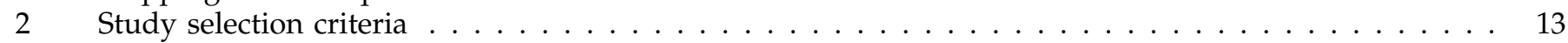

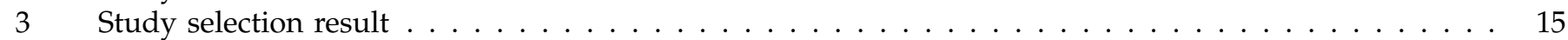

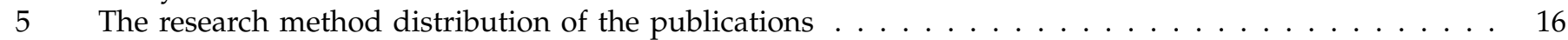

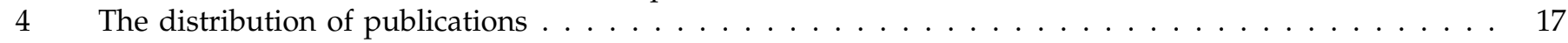

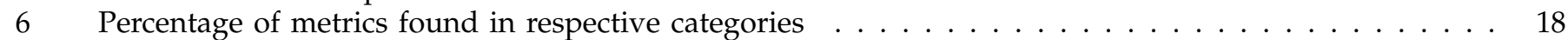

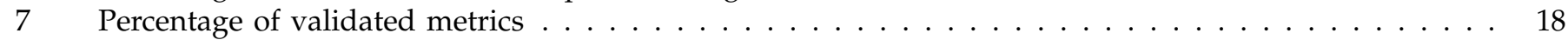

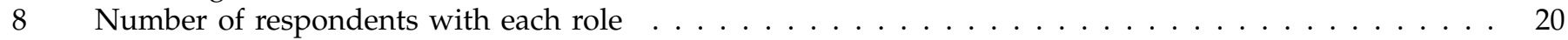

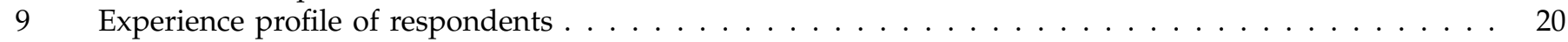

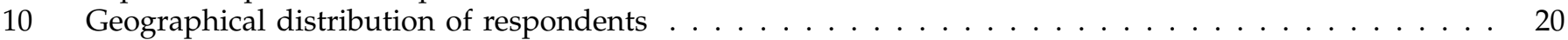

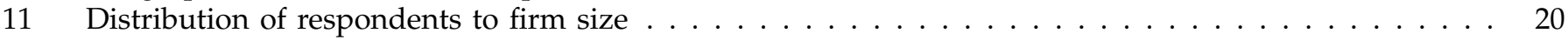

12 Questionnaire responses on what constitutes innovation . . . . . . . . . . . . . . . . . . . . . 24

13 Questionnaire responses on types of innovation . . . . . . . . . . . . . . . . . . . . . . 24

14 Questionnaire response on importance of innovation measurement . . . . . . . . . . . . . . . . . . 25

15 Questionnaire results on innovation strategy and measurement . . . . . . . . . . . . . . . . . . 25

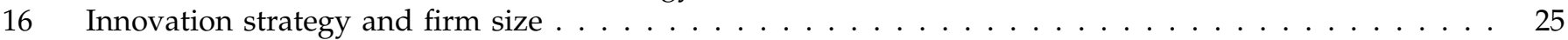

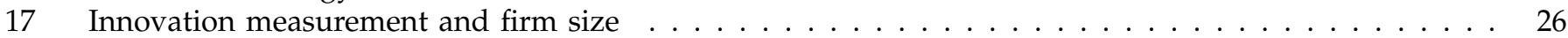

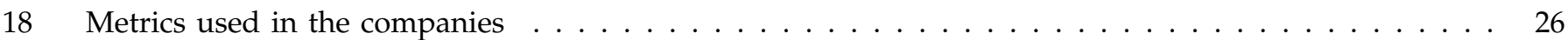

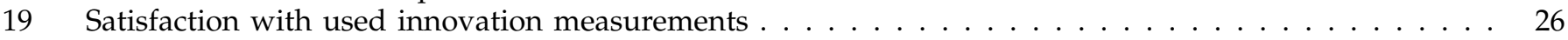

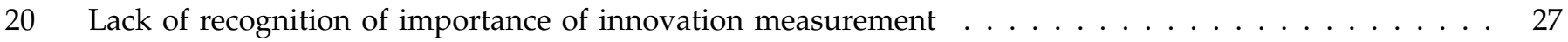

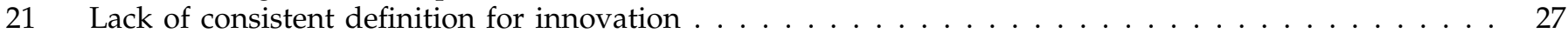

22 Lack of metrics for innovation measurement . . . . . . . . . . . . . . . . . . . . . . . . 27

23 Lack of guidelines and framework for innovation measurement . . . . . . . . . . . . . . . 27

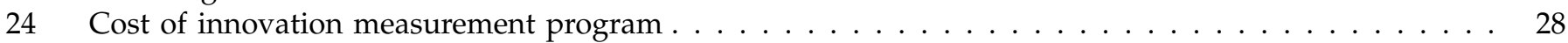

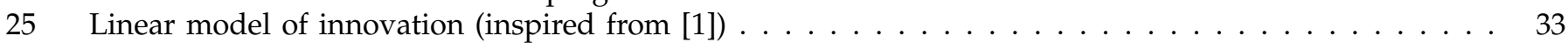

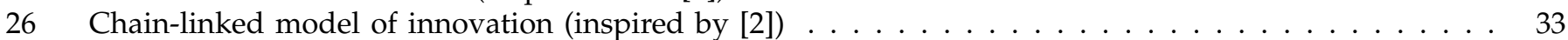

27 Model for innovation measurement . . . . . . . . . . . . . . . . . . . . . . . . . . 34

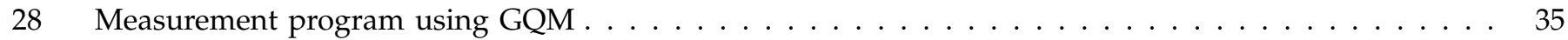




\section{LIST OF TABLES}

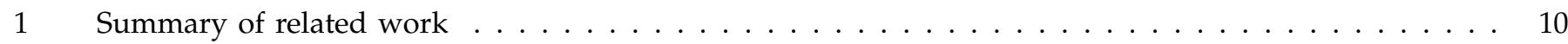

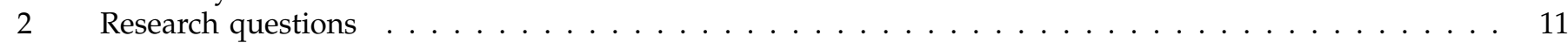

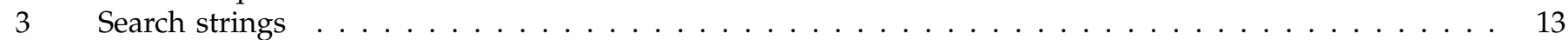

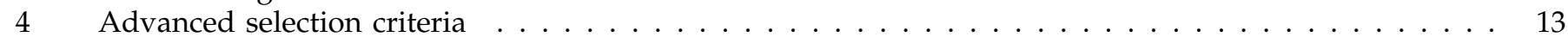

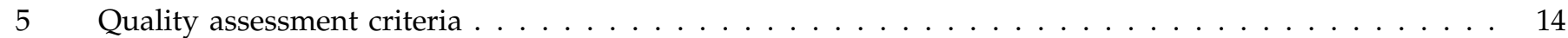

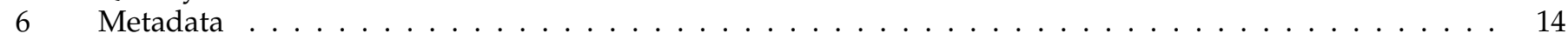

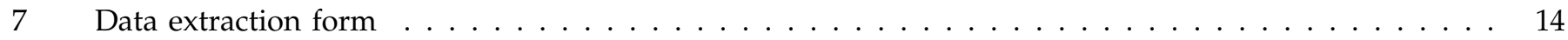

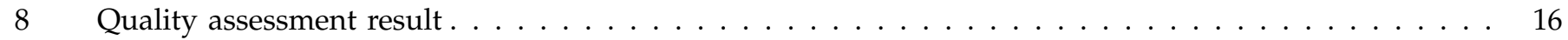

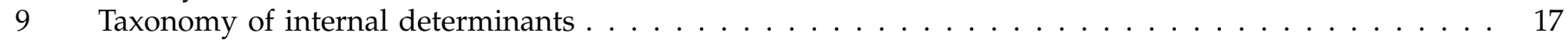

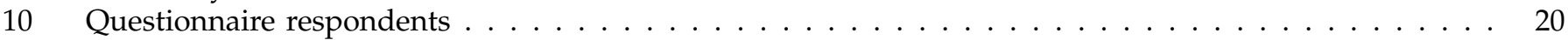

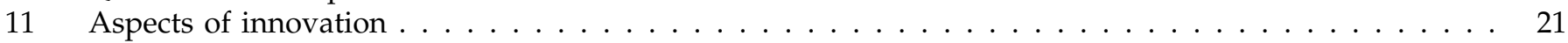

12 Questionnaire respondents' roles and abstraction . . . . . . . . . . . . . . . . . . . 24

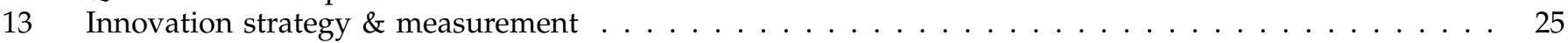

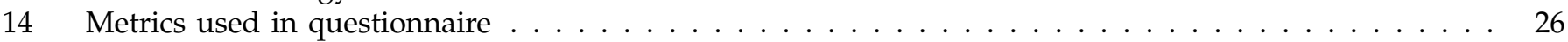

15 Coverage of aspects by different metrics . . . . . . . . . . . . . . . . . . . . 


\title{
Towards innovation measurement in software industry
}

\author{
Nauman bin Ali and Henry Edison
}

\section{INTRODUCTION}

$\mathrm{I}$ NNOVATION is considered a key success factor [3] and central to increasing economic output and productivity [4]. An increasing number of organisations emphasise its critical role in the success and sustainability of business [5] [6] [7] [8]. According to Boston Consulting Group (BCG) [9], 66\% of senior executives consider innovation among their top three strategic priorities. It is the ability to dictate and modify the 'rules of the game' [7] which enables organisations to gain entry to new markets and challenge established market leaders [10]. In past, management has focused on cost, lead time reduction and quality improvement for competitiveness in the market [11]. However, in today's competitive business environment, quality is a necessity but not sufficient enough [11] [12] [13]. Therefore, organisations must continuously innovate, develop new processes and deliver novel products ${ }^{1}$ to achieve and sustain competitive advantage [11] [14].

\subsection{Innovation in software industry}

The modern dynamic business environment is characterised by high competition. This competition is derived from deregulation, empowered customers, new market entrants [14], emerging technology [3] [14] [15], ecommerce [3], globalisation of economy [3] [14] [12] [15] [13], dynamic and complex markets, uncertain economic circumstances and rapid product development [14] [12] [13]. In this environment with shortened product [14] [12] [13] and technology life-cycles [13] [16], software industry is influenced in particular owing to its knowledge intensive [17] and technology driven nature [16]. This calls for innovation to survive, compete, grow and preferably lead the market [15] [13]. Moreover, software innovations have influenced industries and our everyday lives and software has become an integral part of them [18]. This ubiquity of software further necessitates continuous innovation in software more than ever before.

1. In this study, we use the term "products" for both goods and services.

\subsection{Importance of innovation measurement}

Most innovators are the leading companies in a market yet overtime this changes and they are replaced by new emerging firms [14]. Such turnover signifies the importance of sustained innovation thus the problem is not happenstance innovation rather doing it continuously on a regular basis. For sustained innovation to become a reality, a better understanding of innovation is required, which will be possible only when it is measured [19].

Researchers have suggested relation of innovation to organisational structure, culture and knowledge management practices [20] [21]. Similarly, organisations undergo structural changes, pursue policies and spend aggressively to create an environment conducive to creativity and innovation [9] [22]. Innovation measurement can help assess the results and determine whether these changes are paying off. It will further enable a better understanding and development of improved models of evolving innovation process [11].

Practitioners need instruments to assess the innovation management and outcomes as innovation performance is linked with business performance [23]. Managers need appropriate metrics and tools to evaluate and diagnose innovation process and capacity to make informed decisions about innovation programs [14]. Senior management will be able to track innovation performance and adapt the organisations strategy to the outcomes in a more timely way [14]. According to Andrew et al. [24] one of the characteristics of highly innovative firms is that they develop and use meaningful measures to track inputs, performance, cash pay-backs, and indirect benefits for innovation management.

The remainder of this paper is structured as follows. In Section 2, the background of this study is explained. Section 3 discusses the existing research related to this study. Section 4 presents the research methodology undertaken in this study. The results of this study are reported in Section 5, analysed in Section 6 and discussed in Section 7. Section 8 presents the proposed model. In the end, validity threats of the study are discussed in Section 9, the conclusions and future work are covered in Section 10. 


\section{BACKGROUND}

The importance of innovation measurement is well emphasised in industry. According to BCG survey [22], 74\% of executives believe that their company should track innovation as rigourously as core business operations but only $43 \%$ firms actually measure innovation. Although, some firms think that innovation cannot and should not be measured but the real issue is lack of metrics and measurements [22]. This makes companies under measure, measure the wrong things or not measure innovation at all [22]. It has devastating effects in terms of poor allocation of resources, lost opportunities and ill-informed decision making.

Despite the realisation that innovation drives productivity and economic prosperity, there is little consensus on how innovation measurement should be done [25]. This lack of consensus is caused by the different definitions of innovation used. Each of these definitions signify a different aspect of innovation like perspectives, levels and types etc. [18]. This in turn determines what is considered as elements of innovation and how these are measured.

The perspective of innovation adopted by the organisation would delineate the ideal measures of innovation [25]. For some problems a universal yardstick is enough but innovation encompasses creation of new opportunities, businesses, markets, environments, methods of working and operating [26]. In essence no single measure can cover all these constituting aspects of innovation [26]. A survey by BCG [22] found that only $35 \%$ of executives were satisfied with their current innovation measurement practices. Part of the reason for this dissatisfaction could be that most of the firms (i.e. $58 \%$ ) use less than five metrics which is not enough to measure the entire range of innovation activities [22].

Organisations require means not only to measure their innovative output but also to assess their ability and capacity to innovate. Measurement helps to better understand and evaluate the consequences of the initiatives geared towards innovation. Furthermore, like any other measurements these will allow organisations to specify realistic targets of innovation in future, identify and resolve problems hindering progress towards goals, make decisions and continuously improve the abilities to innovate [27].

\section{Related Work}

To the best of our knowledge, there is no systematic review on innovation measurement in software industry. We have identified several studies in other domains that attempt to address the issues which are also the focus of this study. The related work for this study has been summarized in Table 1.

Becheikh et al. [28] conducted a systematic review on technological innovation in manufacturing sector from 1993-2003. It was aimed to find what the main variables are and how they are used to measure the innovation behaviour and capacity of the organization. The study was based on the empirical evidence reported in the journals published in ABI/INFORM of Proquest, Business Source Premier (BSP) of EBSCO, and ScienceDirect of Elsevier. However, the study only considered two areas which are suggested by the Oslo Manual [4]: product and process innovation. Although the study identified 36 internal and 10 external determinants, no framework to measure innovation was proposed.

Systematic review by Crossan et al. [29] found the common definitions and determinants of innovation based on the journal published in ISI Web of Knowledge's Social Sciences Citation Index (SSCI). The study also proposed a comprehensive framework of organizational innovation. However, the study did not focus on software industry and used only one database ISI Web of Knowledge's Social Sciences Citation Index (SSCI).

Several researchers have tried to develop a framework to measure innovation. Berg et al. [30] proposed a model for measuring the front-end innovation activities based on three assessment areas: process, social and physical environment. However, since the model was developed for manufacturing sector, it will need some adjustments before applying it in service sector. Moreover, the proposed model is solely based on Research and Development (R\&D) data. Small Medium Enterprises (SMEs) usually cannot afford to have dedicated R\&D departments [31]. Therefore, this model is not applicable in their context.

Misra et al. [32] proposed a goal-driven measurement framework for measuring innovation activities in an organization. The framework adopted the Goal-QuestionMetric (GQM) approach to define the goals of innovation program and the metrics to measure their achievement. Although they provided a set of metrics for measuring innovation, the study did not present a clear methodology on how they defined the goal, questions and metrics. The study also did not explain clearly the relationship between the suggested metrics and innovation.

Narayana [8] proposed an innovation maturity framework to assess the maturity of the innovation process in a firm. The framework is modelled based on Capability Maturity Model (CMM) as a ladder with five steps. The levels are basic, recognized, managed, assessed and learning/innovation/improving/optimizing. Narayana argued that the success of innovation is determined by the innovation strategy, internal organization, innovation process, understanding customer requirements and technical capabilities. However, the framework has not been validated and it does not provide any metrics to assess the process maturity. Moreover, it only considers R\&D as the main factor to determine the maturity of a process.

In this study, the area of innovation measurement was explored. The study attempts to contribute to the innovation measurement body of knowledge for software industry. By performing systematic literature review, the study has established the state-of-the-art of innovation measurement. The findings of the literate review were 
Table 1

Summary of related work

\begin{tabular}{|c|c|c|c|c|c|}
\hline Study & $\begin{array}{l}\text { Research } \\
\text { methodology }\end{array}$ & Domain & Document type & Databases & Result \\
\hline $\begin{array}{l}\text { Becheikh et al. } \\
\text { [28] }\end{array}$ & $\begin{array}{l}\text { Systematic } \\
\text { review }\end{array}$ & Manufacturing & Journal article & $\begin{array}{l}\text { Proquest, BSP and Sci- } \\
\text { enceDirect }\end{array}$ & $\begin{array}{l}\text { A set of variables related to the } \\
\text { innovation process and the determi- } \\
\text { nants }\end{array}$ \\
\hline Crossan et al. 49 & $\begin{array}{l}\text { Systematic } \\
\text { review }\end{array}$ & General & Journal article & $\begin{array}{l}\text { ISI Web of Knowledge's } \\
\text { SSCI }\end{array}$ & $\begin{array}{l}\text { A multi-dimensional framework of } \\
\text { organizational innovation - linking } \\
\text { leadership, innovation as a process, } \\
\text { and as an outcome }\end{array}$ \\
\hline Berg et al. [30] & $\begin{array}{l}\text { Conceptual } \\
\text { analysis }\end{array}$ & Manufacturing & Proceeding & Not specified & $\begin{array}{l}\text { Framework of the model for } \\
\text { measuring the innovation activities } \\
\text { front end }\end{array}$ \\
\hline Misra et al. [32] & $\begin{array}{l}\text { Conceptual } \\
\text { analysis }\end{array}$ & Software firms & Journal article & Not specified & $\begin{array}{l}\text { Measurement framework for soft- } \\
\text { ware innovation process }\end{array}$ \\
\hline Narayana [8] & $\begin{array}{l}\text { Conceptual } \\
\text { analysis }\end{array}$ & Software firm & Proceeding & Not specified & $\begin{array}{l}\text { CMM-based Innovation Maturity } \\
\text { Model }\end{array}$ \\
\hline
\end{tabular}

complemented with a questionnaire and interview to elicit the perception of innovation and the state of practice in the industry. The study results consist of:

1) Definitions of innovation reported in the literature.

2) Software industry's perception of innovation.

3) A comprehensive definition that may be used in software industry.

4) The state of practice of innovation measurement in software industry.

5) Key aspects of innovation measurement.

6) Classification of determinants of innovation (including the ones which have been validated for software industry).

7) Classification of metrics that may be used to measure innovation in software industry.

8) A conceptual model for innovation measurement.

\section{ReseaRCH METHOdOLOGY}

\subsection{Research questions}

The aim of this study is to identify and elaborate the key concepts of innovation measurement in software industry. The aim will be achieved by addressing the following objectives:

1) To identify the perception of innovation in software industry and the definitions of innovation in the published literature.

2) To identify the determinants or drivers of innovation in software industry.

3) To identify the commonly used metrics to assess innovation.

4) To identify the existing innovation measurement models and major challenges in evaluating innovation.

5) To formulate and illustrate the key concepts of innovation measurement.

Table 2 presents an overview of the research questions that will be answered in this study.

A mixed methods research was used to achieve the aim of this study. According to Creswell [33], using mix methods research, data collection phase in quantitative and qualitative methods can be conducted either sequentially or concurrently. In sequential strategy, the weight is given to the first method and the result of the second method is built on the result of the first method. On the other hand, data collection for both methods in concurrent strategy are conducted concurrently and followed by analysis of the results to see if there is convergence or divergence or combination of both.

The mix methods research used in this study is sequential transformative strategy [33]. In this strategy, a qualitative method was employed in the initial phase followed by quantitative methods. The purpose of qualitative method was to build the theoretical perspective. It served as the guideline to shape the direction of the study whereas the quantitative study was intended to give researchers better understanding of the phenomenon [33].

Qualitative methods used in this study were systematic literature review, conceptual analysis and face-toface interviews. Systematic literature review was conducted to answer RQ1, which was intended to aggregate four main data from existing literature: definition of innovation, determinants of innovation process, metrics used to measure innovation and existing innovation measurement frameworks.

To answer RQ2, we used questionnaire and face-toface meetings to collect opinions of software industry practitioners and academics. By using questionnaire, we can reach more respondents than face-to-face meetings. The main goals of questionnaire were to get the perception of industry about innovation, innovation measurement and insight to current measurement practices. The results of the questionnaire were used to confirm the findings of systematic review.

Based on the findings from systematic literature review and questionnaire, we conducted content analysis to answer RQ3. Content analysis is used to 'categorise qualitative textual data into clusters of similar, or conceptual categories, to identify consistent patterns and 
Table 2

Research questions

\begin{tabular}{|c|c|c|}
\hline & "Research Question & Objective \\
\hline RQ1.1 & What definitions of innovation are reported in literature? & $\begin{array}{l}\text { To understand perception of the term and to indicate the commonly } \\
\text { used definition in literature. }\end{array}$ \\
\hline RQ1.2 & What are the determinants of innovation? & $\begin{array}{l}\text { To identify the determinants, drivers, factors and key elements for } \\
\text { innovation in software industry. }\end{array}$ \\
\hline RQ1.3 & $\begin{array}{l}\text { What metrics are reported in the literature to measure } \\
\text { innovation? }\end{array}$ & $\begin{array}{l}\text { To identify metrics, their perspective, context, definition and relation- } \\
\text { ship to innovation as proposed in literature for innovation measure- } \\
\text { ment. }\end{array}$ \\
\hline RQ2 & $\begin{array}{l}\text { What is the state of practice of innovation measurement } \\
\text { in software industry? }\end{array}$ & $\begin{array}{l}\text { To characterise the practice of innovation measurement, presence of } \\
\text { strategies, policies, processes related to innovation. Identifying the } \\
\text { frameworks, metrics and issues faced by industry in innovation mea- } \\
\text { surement. }\end{array}$ \\
\hline RQ2.1 & What is perceived as innovation in software industry? & $\begin{array}{l}\text { To understand perception of the term in industry and to validate the } \\
\text { findings of the literature review. }\end{array}$ \\
\hline RQ2.4 & What frameworks are used to measure innovation? & $\begin{array}{l}\text { To identify the existing methods used for innovation measurement in } \\
\text { software industry. }\end{array}$ \\
\hline RQ2.5 & $\begin{array}{l}\text { Which are the important challenges in innovation mea- } \\
\text { surement for software industry? }\end{array}$ & $\begin{array}{l}\text { To identify what are the challenges faced by software industry in } \\
\text { innovation measurement. }\end{array}$ \\
\hline RQ3 & $\begin{array}{l}\text { What are the key elements that need to be considered in } \\
\text { innovation measurement (motivated by findings of RQ1 } \\
\text { and RQ2)? }\end{array}$ & $\begin{array}{l}\text { To analyse the definitions, determinants and proposed metrics for } \\
\text { innovation measurement for software industry. }\end{array}$ \\
\hline
\end{tabular}

relationship between variables or theme' [34]. There are two types of content analysis: conceptual analysis and relational analysis. In this study, we followed the steps of conceptual analysis to examine innovation and quantifying its presence as described in [35].

There are 8 steps in conceptual analysis [35]:

1) Deciding the level of analysis. In this step, individual words or phrases that will be analysed are defined.

2) Deciding how many concepts to code for. In this step, researchers decide whether to code the predefined or interactive set of concepts.

3) Deciding whether to code for existence of frequency of a concept. In this step, researchers decide whether to code the existence or the frequency of the concept.

4) Deciding on how to distinguish among concepts. If two concepts that express the same idea are found in the paper, the researchers must decide whether to code them in the same or a separate group.

5) Developing rules for coding the text. In this step, researchers define a set of rules that allow them to code the concepts consistently.

6) Deciding what to do with 'irrelevant' information. Not all information is relevant to the study. Therefore, researchers must decide whether to ignore or re-examine the irrelevant information.

7) Coding the texts. After deciding the concepts and the rules, researchers perform the actual coding.
8) Analysing the results. After completing the coding, researchers analyse the data. Based on this data, researchers are able to draw conclusions and generalisation.

In this study, step 1-6 were incorporated as part of systematic literature review. The data that would be analysed were defined systematically (see Section 4.2.1, $4.2 .2,4.2 .3,4.2 .4)$. Step 7 was conducted as the data extraction strategy (see Section 4.2.5).

Using conceptual analysis method, we developed an innovation measurement model (see Section 6). To validate the model, static validation [36] was performed through interviews with industry practitioners and academics. Beside to capture the perception of innovation and state of practice regarding innovation measurement in software industry, industrial interview was also intended to evaluate the usefulness and applicability of the proposed model in industry. On the contrary, academic interview was mainly focused on the completeness and correctness of the proposed model. The mapping of research methods and research questions is shown in Fig. 1.

\subsection{Systematic Literature Review}

Systematic literature review is a systematic approach to identify, evaluate and interpret research available about a particular area of interest [37]. It is a structured and repeatable process with predefined search strategy to 
Fig. 1. Mapping research questions to research methods

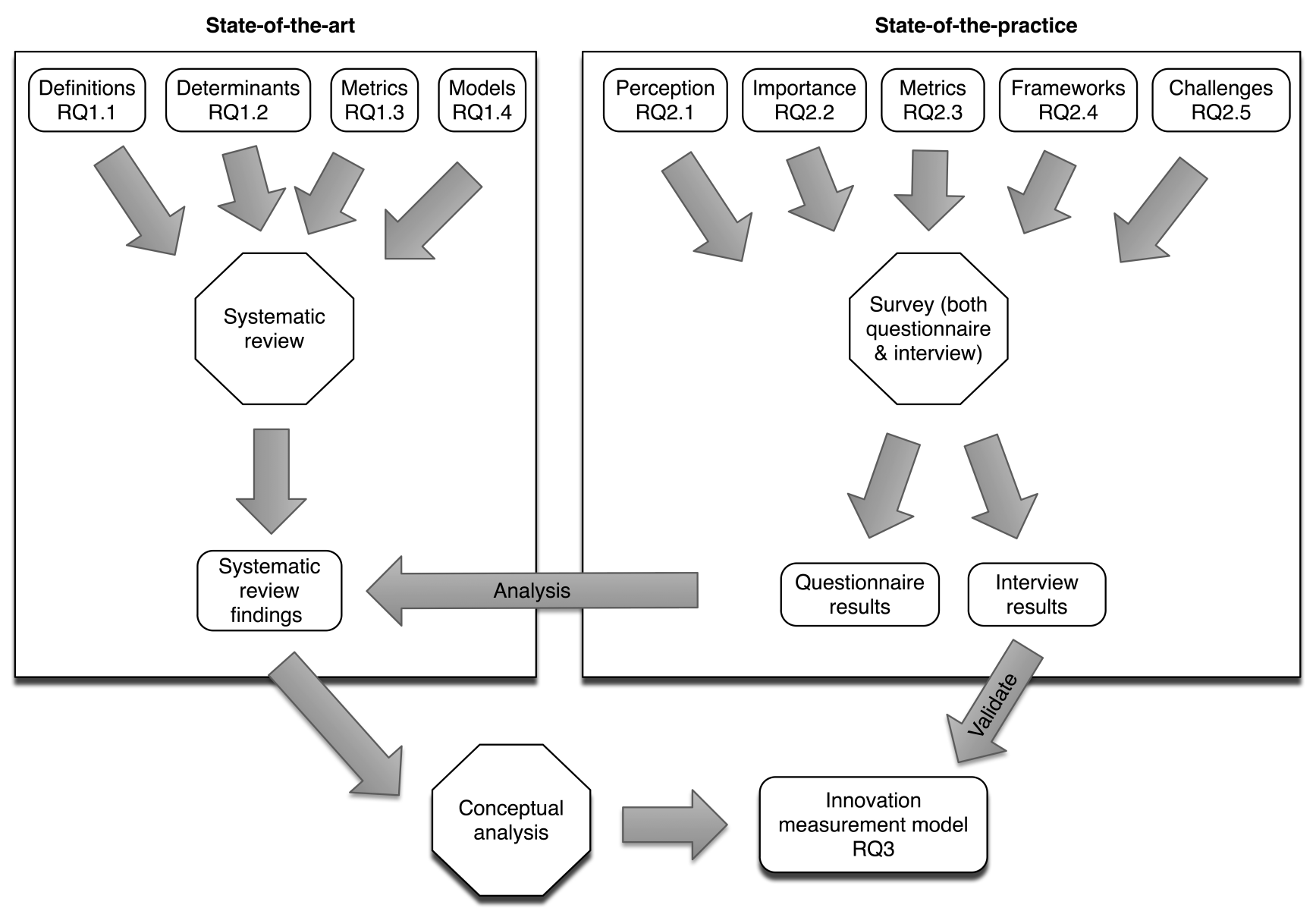

comprehensively aggregate the published literature. Use of predefined strategy provides an unbiased approach to identification of primary studies [37]. Systematic review is a secondary study of accumulated primary studies that aims to improve the understanding and to ascertain the validity and reliability of claims and propositions [37] [38].

The systematic review as proposed by Kitchenham et al. [37] consists of three major phases:

1) Planning the review. In this phase, the need for the systematic review is justified and the review protocol (research questions, search strategy and selection criteria) is developed.

2) Conducting the review. This phase involves identification of research, selection of studies based on criteria developed in review protocol, data extraction and data synthesis.

3) Reporting the review. This phase involves writing a report to effectively communicate the results.

A defined review protocol, search strategy, explicit inclusion and exclusion criteria, and specified information that will be retrieved from primary studies differentiates a systematic review from a conventional literature review [37].

In the following sections (Section 4.2.1, 4.2.2, 4.2.3,
4.2.4 and 4.2.5) we describe the first phase (planning) of this review. The results of this systematic review are reported in Section 5.1.

\subsubsection{Search strategy}

In this study, we used seven online databases to perform the search: Inspec and Compendex (through Engineering Village), Scopus, IEEE Xplore, ACM Digital Library, ScienceDirect and Business Source Premier (BSP). The target for this review was journals published in engineering, economics, computer science, finance and management.

To ensure that all the performed searches were consistent and comparable for each database, we used selected keywords and expressions derived from the research questions in Table 2. Table 3 presents the generic search string with combination of keywords to answer the research questions. The actual search strings used in individual databases are presented in Appendix A.

From the pilot selection result, we found the studies that discuss measurement framework also discuss the definition and different aspects of innovation. Furthermore, the keyword innovation itself was so generic. When a new keyword, e.g. 'define' was added, the search hits started increasing exponentially and giving mostly irrelevant results. Therefore, RQ1 was answered 
Table 3

Search strings

\begin{tabular}{|c|c|}
\hline Search string & $\begin{array}{l}\text { Research } \\
\text { question }\end{array}$ \\
\hline $\begin{array}{l}\text { ("innovation" AND ("evaluat*" OR "assess*" OR } \\
\text { "measur" OR "metric*" OR "determinant" OR } \\
\text { "driver" OR "key elements" OR "indicator*" OR } \\
\text { "attribute")) }\end{array}$ & RQ1 \\
\hline
\end{tabular}

indirectly from the studies found using the same search string.

\subsubsection{Study selection criteria and procedure}

All potential primary studies were reviewed based on three selection criteria. Fig. 2 presents the study selection process. Three inclusion/exclusion criteria were defined to select the relevant articles for this study. The preliminary criteria were intended to make sure the uniqueness of the article. In this phase, we only considered those primary studies, which are published in journals and are written in English. No duplicate studies were allowed.

Fig. 2. Study selection criteria

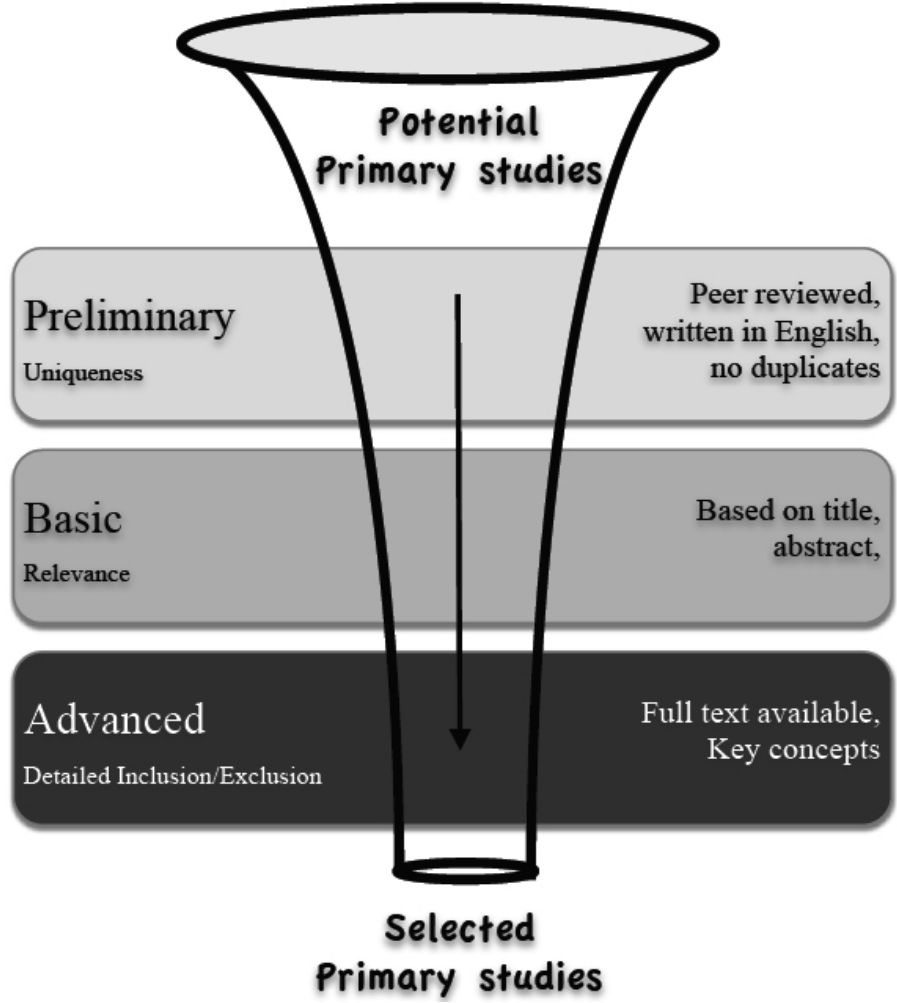

The second inclusion/exclusion criteria were based on the relevance of the primary studies to innovation and innovation measurement. The relevance of the studies was decided after reading the title and abstract. If after reading the title and abstract a decision cannot be made, we read the introduction and conclusion. If there was still an uncertainty about the paper, it was classified as 'Doubtful' and submitted to discuss with the second reviewer for the final judgement.
It was not necessary for them to be available in digital format, because we had collaborated with a librarian to retrieve the articles in the printed format. However, the primary studies, which we could not get until the end of systematic review process, were rejected. Once we got the full-text, we included those studies that have discussed the key concepts in innovation and innovation measurement. Table 4 presents the detailed inclusion / exclusion criteria for this study.

Table 4

Advanced selection criteria

\begin{tabular}{ll}
\hline \hline \multicolumn{1}{c}{ Inclusion / exclusion criteria } \\
\hline 1 & Full-text is available \\
2 & The article discusses a definition of innovation \\
3 & The article discusses the determinants of innovation \\
4 & $\begin{array}{l}\text { The article describes one or more metrics to measure innova- } \\
\text { tion }\end{array}$ \\
5 & $\begin{array}{l}\text { The article gives an overview of a model or framework for } \\
\text { innovation measurement }\end{array}$ \\
6 & $\begin{array}{l}\text { The article compare two or more existing frameworks for } \\
\text { innovation measurement }\end{array}$ \\
7 & $\begin{array}{l}\text { The article discusses the validation of the existing framework } \\
\text { for innovation measurement }\end{array}$ \\
8 & The article analyses or evaluates \\
\hline \hline
\end{tabular}

\subsubsection{Pilot selection}

Before performing the actual selection procedure a pilot selection was performed where both reviewers applied selection criteria on same 30 papers, individually. Then the results were compared to see if the two reviewers had a shared understanding of the criteria. By discussing the conflicts a coherent understanding of the criteria and procedure was developed. After having the same understanding, reviewers performed the actual studies selection. The list of studies extracted from the resources was divided equally among the reviewers and each member did selection independently.

\subsubsection{Study quality assessment criteria}

As suggested by Kitchenham [37], we developed a checklist to assess the quality of the selected primary studies. This assessment was not part of data extraction form as it was assessed separately. The primary studies were evaluated based on the quality criteria presented in Table 5. The quality criteria were rated according to a 'Yes', 'No' and 'Partially'. Each study got 1 if it had 'Yes', 0 if it had 'No' and 0.5 if it had 'Partially' for each fulfilled quality criterion.

\subsubsection{Data extraction strategy}

Before executing the data extraction, we performed a pilot extraction to ensure that each reviewer understood and had the same interpretation of the form and data to be extracted. The pilot extraction was performed in a manner similar to the studies selection procedure. After having the same understanding and interpretation of the data extraction strategy, the actual data extraction was 
Table 5

Quality assessment criteria

\begin{tabular}{lll}
\hline \hline & Criteria & $\begin{array}{l}\text { Yes / No / } \\
\text { Partially }\end{array}$ \\
\hline 1 & Is the aim of the study clearly explained? \\
2 & $\begin{array}{l}\text { Is the presented methodology/approach } \\
\text { clearly stated? }\end{array}$ \\
3 & $\begin{array}{l}\text { Are the threats to validity of the study anal- } \\
\text { ysed? }\end{array}$ \\
4 & $\begin{array}{l}\text { Is an appropriate definition of innovation } \\
\text { provided? }\end{array}$ \\
5 & $\begin{array}{l}\text { Are the empirical evidences provided in the } \\
\text { study? }\end{array}$ \\
\hline \hline
\end{tabular}

performed. While reading the full-text of the studies, key concepts from each study were extracted according to the form shown in Table 6 \& Table 7.

Table 6

Metadata

\begin{tabular}{l}
\hline \hline Title: \\
Authors: \\
Publication Date: \\
Source: \\
Database: \\
\hline \hline
\end{tabular}

\subsection{Interview}

Interview is a commonly used method in qualitative research [33] [39] [40]. The aims of interview are to collect historical data from interviewee's memories, to gather the opinions or impression about something or to identify the terminology in a particular setting [39]. For this purpose, interview can be done through three methods [39]:

1) Structured interview. In this method, the interviewer has prepared all the questions clearly and specific.

2) Unstructured interview. Opposed to structured interview, the interviewer does not know clearly about information that he or she is looking for. Therefore, the questions are asked as open-ended as possible.

3) Semi-structured interview. In this method, a mix of open-ended and specific questions is employed to elicit information.

According to Creswell [33], interview can be conducted either by having face-to-face (one-on-one, in person) interview, telephone interview, focus group or email interview. In this study, we conducted face-to-face interviews with both academia and industry practitioners each lasting for one hour. We used semi-structured method to grasp as much information as we could get from the interviewees. While conducting the interview, we followed the interview protocol as described in Creswell [33]:
Table 7

Data extraction form

\begin{tabular}{|c|c|c|}
\hline Data item & Data value & $\begin{array}{l}\text { Mapping to } \\
\text { RQ }\end{array}$ \\
\hline Definition & $\begin{array}{l}\text { - Innovation definition } \\
\text { - Domain: business, } \\
\text { manufacturing, software } \\
\text { engineering, other }\end{array}$ & RQ1, RQ1.1 \\
\hline $\begin{array}{l}\text { Innovation } \\
\text { determinants }\end{array}$ & - Internal & RQ1, RQ1.2 \\
\hline Metrics & $\begin{array}{l}\text { - Name of the proposed met- } \\
\text { rics } \\
\text { - Purpose } \\
\text { - Type of metrics: basic or de- } \\
\text { rived } \\
\text { - Description of the metrics } \\
\text { - Attributes } \\
\text { - Measurement method } \\
\text { - Measurement function / } \\
\text { - Computation } \\
\text { - Type of scale } \\
\text { - Unit of measurement } \\
\text { - Interpretation } \\
\text { Validation: industry or aca- } \\
\text { demic }\end{array}$ & RQ1, RQ1.3 \\
\hline $\begin{array}{l}\text { Measurement } \\
\text { framework }\end{array}$ & $\begin{array}{l}\text { - Name of the proposed } \\
\text { framework } \\
\text { - Description of the frame- } \\
\text { work } \\
\text { - New or extension of the ex- } \\
\text { isting framework } \\
\text { - Limitation of the frame- } \\
\text { work } \\
\text { - Means of representation } \\
\text { (mathematical formula, } \\
\text { table, diagram) } \\
\text { - Validation: industry or aca- } \\
\text { demic }\end{array}$ & RQ1, RQ1.4 \\
\hline
\end{tabular}

1) A heading (date, place, interviewer, interviewee). Standard procedure for interviewer while conducting the interview

2) The questions (typically icebreaker questions at the beginning, followed by 4-5 questions from the list).

3) Probe 4-5 questions to follow up, based on the interviewee's answer.

4) A final thank you statement to acknowledge the time the interviewee spent.

The details of semi-structured interview questions used in this study are presented in Appendix K.

\subsection{Questionnaire}

To supplement the answers to the research questions of this study we conducted an explorative questionnaire [41]. Questionnaires are a good instrument to conduct opinion polls [41]. The purpose of this questionnaire was to identify the perception of innovation, importance of innovation measurement, metrics, frameworks and 
perceived difficulties and challenges in innovation measurement.

Questionnaire served as an instrument to collect the experts' opinions that we could not interview face-toface. The target respondents were software industry practitioners i.e. software engineers, analysts, project managers, R\&D managers, CTO, CEO, etc. We followed the main steps in developing questionnaire as suggested by Kasunic [42]:

1) Determine the question to be asked. In this step, researchers decide what information they need to collect. There are four types of information that can be asked: attributes, attitudes, beliefs or behaviours.

2) Select the question type, format and specific wording. In this step, researchers develop the actual questionnaire so the responses can be analysed and understandable to the target respondents.

3) Design the question sequence and overall questionnaire layout. In this step, researchers decide the length of the questionnaire, the sequence of the questions, the transition paragraph and questionnaire layout.

4) Develop ancillary documents. Before distributing the questionnaire, researchers need to prepare documents that serve as pre-notification letter, reminder letter or thank you letter.

In this study, we developed web-based questionnaire, which was hosted at www.surveymonkey.com.

\subsubsection{Pilot questionnaire}

The purpose of this pilot was to find out the drawbacks or flaws in the questionnaire. It was also aimed to see if the respondents understand and get the same message that we try to give in the questionnaire. Therefore, to assess the clarity, we sent out the initial questionnaire to the students of Blekinge Institute of Technology (BTH). We also observed one student while he was participating in the pilot questionnaire and asked him to tell us his understanding of the questions. We obtained feedback from eight students, who found that some questions were similar and more than one choice appeared correct. Based on their feedback, some of the question were rephrased and re-structured to make it more clear and precise. We also re-designed the layout to make it simpler. Before sending out for execution, we sent out the questionnaire to our supervisor for approval.

\subsubsection{Questionnaire execution}

To get a higher response rate, a personalised email was sent to industrial contacts for invitation to participate in the questionnaire. The request for participation was also posted on researchers' respective alumni mailing lists. As suggest by [42], the invitation was enclosed with cover letter describing the purpose of the questionnaire, anonymity or confidentiality, estimated time to complete the questionnaire, the deadline for completing the questionnaire and email address to contact if the respondents had any concerns. The detail questionnaire used in this study is presented in Appendix M. Due to limited time, we gave seven days for respondents to complete the questionnaire. The data submitted by respondents was taken into consideration only if the respondents fully completed the questionnaire within the deadline.

\section{Results}

\subsection{Systematic Literature Review}

The following section describes the selection results and the characteristics of the selected primary studies.

\subsubsection{Primary studies selection}

We executed the same search strings in different database meeting their particular format requirements. The detailed search strings used in this study are presented in Appendix A.

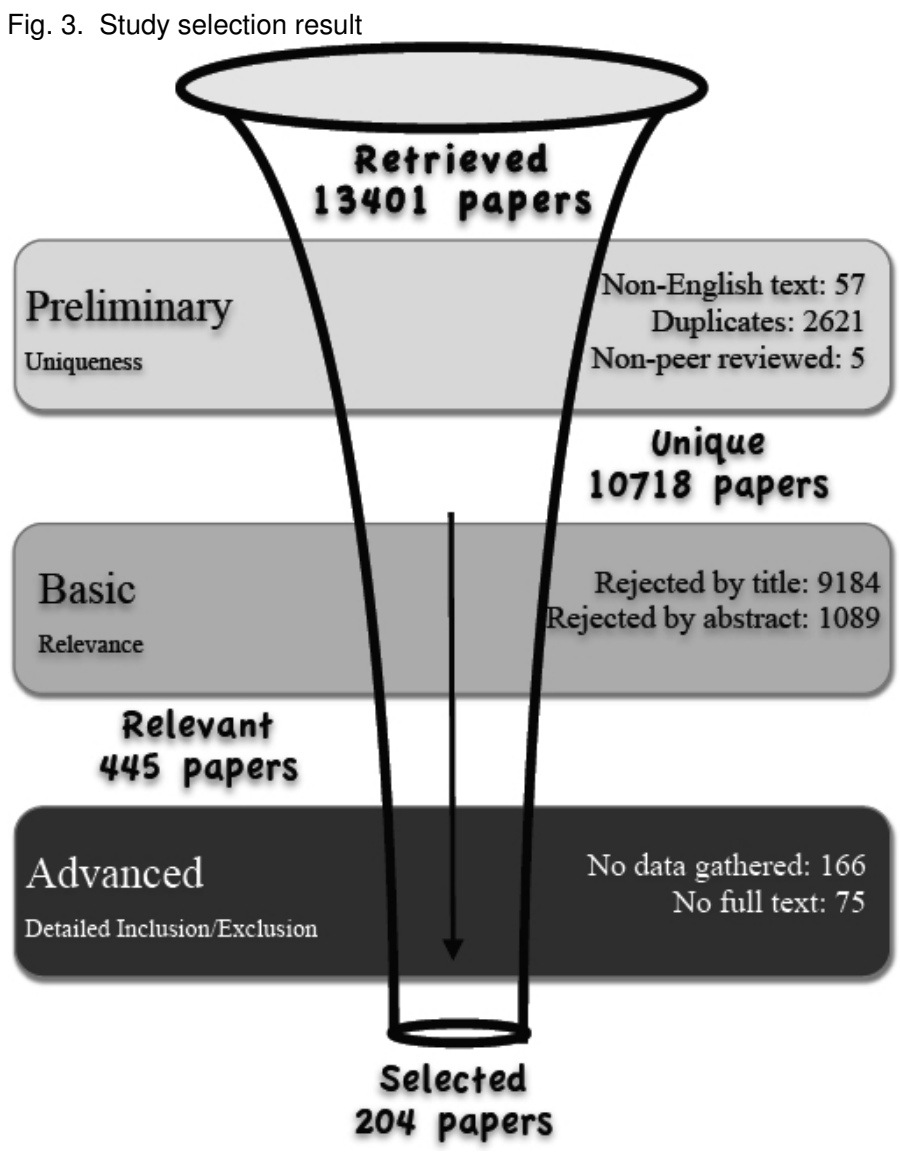

We retrieved a total of 13,401 articles (see Fig. 3) from all databases. The papers were divided among two reviewers for primary studies selection. We used EndNoteX3 as the reference management tool to generate the bibliography, categorise the papers, identify duplicates, sorting and ordering the papers, etc. In the preliminary selection, we rejected 2,683 articles due to the non-English text, duplicate articles and non-reviewed articles. Applying the relevance criteria, we rejected 10,273 articles based on title and abstract. We applied 
advanced criteria to the remaining articles and filtered out 75 of them, which were unavailable in full-text. We also rejected 166 articles since they did not discuss the key concepts that we were looking for and accepted 204 remaining articles as the selected primary studies.

\subsubsection{Quality of primary studies}

Table 8 presents the quality assessment result of the selected primary studies. It can be seen that most of the studies have a good quality according to criteria 1, 2 and 5. Although 87 studies were empirical studies, not all of these discuss the validity threats. Moreover, 42 studies were industry reports which did not clearly state the methodology used. This explains why it is only a few studies discuss the validity threats (criteria 3). More discussion about type of studies is described in Section 5.1.4.

Only 23 studies formulated their own definitions of innovation or used the existing definitions, which were used as the basis of the studies. 26 studies did not clearly define innovation and 152 studies did not have an appropriate definition for the studies (criteria 4).

Table 8

Quality assessment result

\begin{tabular}{lllll}
\hline \hline & Inclusion/Exclusion criteria & \multicolumn{3}{c}{ Number of publications } \\
\cline { 2 - 4 } & Yes & Partially & No \\
\hline 1 & $\begin{array}{l}\text { Is the aim of the study clearly } \\
\text { explained? }\end{array}$ & 194 & 2 & 8 \\
2 & $\begin{array}{l}\text { Is the presented methodol- } \\
\text { ogy/approach clearly stated? }\end{array}$ & 121 & 24 & 59 \\
3 & $\begin{array}{l}\text { Are the threats to validity of the } \\
\text { study analysed? }\end{array}$ & 42 & 16 & 146 \\
4 & $\begin{array}{l}\text { Is an appropriate definition of } \\
\text { innovation provided? }\end{array}$ & 41 & 12 & 151 \\
5 & $\begin{array}{l}\text { Are the empirical evidences pro- } \\
\text { vided in the study? }\end{array}$ & 91 & 9 & 104 \\
\hline
\end{tabular}

\subsubsection{Publications' year}

Fig. 4 shows the year of publications of the selected primary studies. Research on innovation measurement has been conducted in multidiscipline areas [43] and it seems that it still continues until now. There is a trend that the number of published studies is increasing every year and it is likely to continue in the future. This indicates the importance of innovation measurement is growing significance. From 204 selected primary studies, we found that 23 studies were based on software industry (see Appendix J).

\subsubsection{Research method}

The goal of this identification was to see the trend of selected primary studies from the viewpoint of the used research methods. The primary studies were classified based on the research method mentioned in the article. Hence, the categories of the studies are:

- Survey: The studies use either questionnaire or interview (or both) to collect empirical data.
- Case study: The studies declare the use of case study to answer one or more research questions.

- Experiment: The studies use an experiment to examine the hypothesis. The studies also clearly describe the design of the experiment.

- Conceptual analysis: The studies present a theoretical concept without empirical evaluation.

- No research method specified: All the studies that do not state explicitly the research method used are grouped in this category. It includes the studies that report industrial or regional level i.e. individual country or groups of countries experience (e.g. European Union).

Fig. 5. The research method distribution of the publications

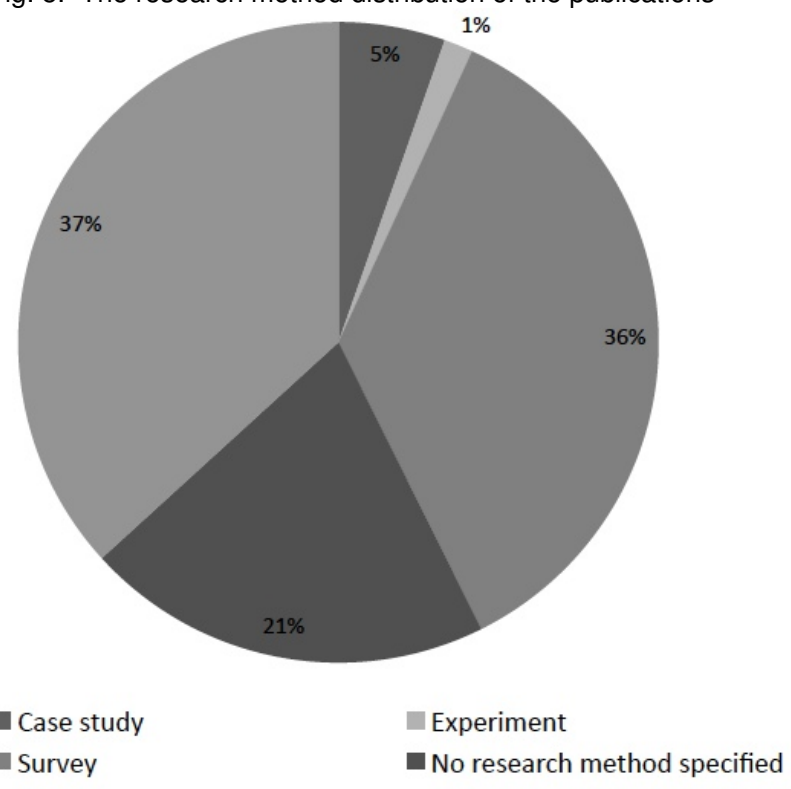

Conceptual analysis

Fig. 5 shows that $37 \%$ of the studies used conceptual analysis and $36 \%$ of the studies used survey. Survey is considered as the main instrument to collect quantitative \& qualitative data followed by statistical analytic methods to validate the concept. There are some studies that present a theoretical concept but use existing or published data to evaluate the concept. In this study, these studies are considered as non-empirical studies as the researchers just took freely available data and did not collect the data by themselves. However, these studies are marked as 'conceptual analysis with empirical evaluation' and treated as subset of this category. There is also a trend that research in innovation measurement used conceptual analysis with empirical evaluation method. $20 \%$ of the primary studies used data from existing sources, primarily from Community Innovation Survey (CIS) database. Only $17 \%$ of the studies are pure conceptual analysis.

\subsubsection{Definitions of innovation}

From 204 selected primary studies, we identified 41 definitions of innovation. These definitions were found 
Fig. 4. The distribution of publications

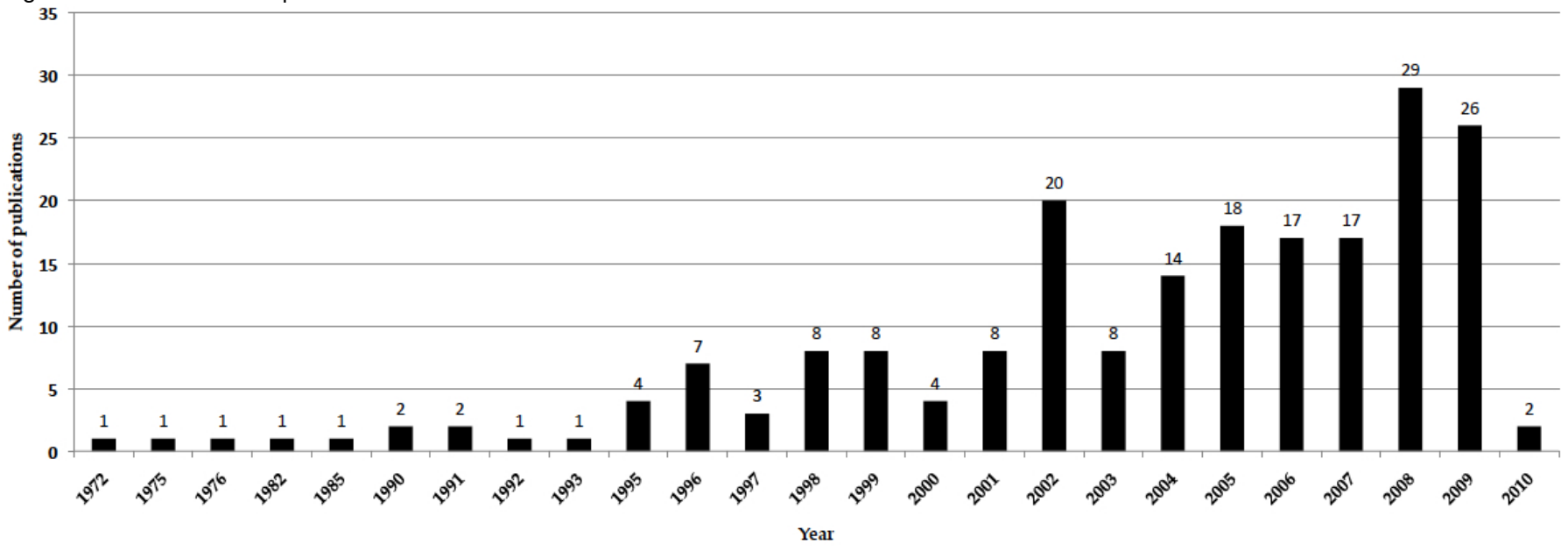

in 41 different studies. Some of studies considered innovation in different terms, i.e. product, process, market, innovation, etc. Most of the definitions have a different point of view e.g. Caloghirou et al. [44] defined innovation in knowledge creation perspective as they wrote 'Innovation can be better understood as a process in which the organisation creates and defines problems and then actively develops new knowledge to solve them'. Jong et al. [45] looked at innovation in organisational perspective when they said 'Innovation behaviour can be defined as all individual actions directed at the generation, introduction and application of beneficial novelty at any organisation level'. Appendix B presents the detailed definitions of innovation found in the literature review.

\subsubsection{Determinants of innovation}

We identified 244 determinants of innovation and classified them into two groups: external determinants and internal determinants. This classification was created based on the sources of factors, whether from outside or inside the organisation. External determinants are factors outside organisation that affects innovation and are beyond the control of the organisation e.g. public policy which reduces the tax for start-ups companies or R\&D grant for small companies [46]. Internal determinants are factors inside the organisations influence that improve the innovation capability of the organisation e.g. the availability of strategy on innovation, creative climate [47].

We also categorised the individual internal determinants into groups based on their meanings and purpose. For example, we grouped the determinants related to customers into customer-related determinants and the determinants associated with marketing into marketing related determinants. Table 9 presents the taxonomy of internal determinants.

Out of the 28 groups of internal determinants, we found only six determinants have been studied in software industry. These were customer-related, strategy related, champions, internal collaboration, networking,
Table 9

Taxonomy of internal determinants

\begin{tabular}{ll}
\hline \hline Market & Knowledge \& information \\
Technology & Empowerment \\
Tool-support & Planning \\
R\&D & Acquisition \& alliances \\
Champions & Intellectual property \\
Alignment & Size \\
External collaboration & Structure \\
Financial & Culture \\
Management & Commitment \\
Risk & Trust \\
Organisation resources & Individual \\
Customer-orientation & Strategy \\
Policy & Internal collaboration \\
Networking & Human resources \\
\hline \hline
\end{tabular}

and human resources. Appendix $\mathrm{C}$ presents the determinants of innovation found in this study.

\subsubsection{Metrics of innovation measurement}

A large number of metrics have been suggested in the literature to measure innovation. The 275 metrics identified are classified into three levels:

- Firm level: These metrics are used to measure innovation within the organisation.

- Industry level: These metrics are used to measure innovation in industry level, e.g. software industry, manufacturing industry, etc.

- Regional level: Some metrics are used to measure innovation in regional level, e.g. European countries.

This classification was based on the context of the studies. We found that most of the studies focus on innovation at firm's level (as shown in Fig. 6).

$37 \%$ of the metrics found in the literature have been statically validated. Most of these metrics are validated through statistical analysis on empirical data. The data may have been collected directly from industry or from published data or existing databases. The majority of the metrics 58\% were mere suggestions and have not been 
Fig. 6. Percentage of metrics found in respective categories

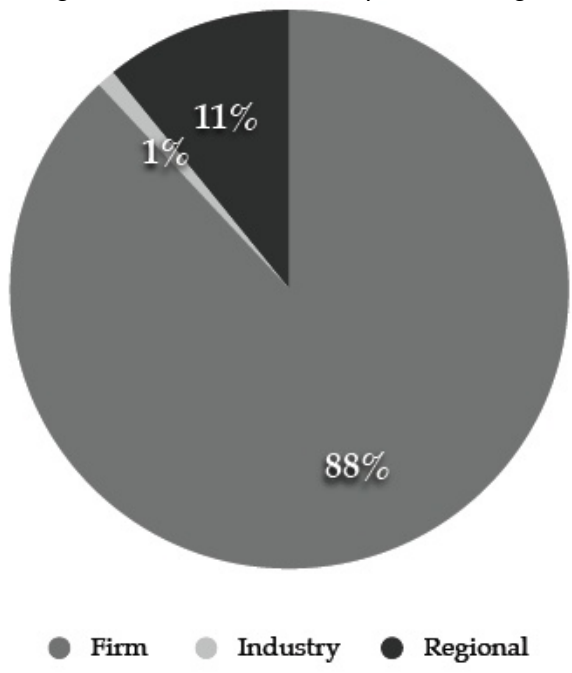

subjected to any validation or used in practice. Only $5 \%$ of the metrics have been used in industry but no information about the validation of these metrics was available.

Fig. 7. Percentage of validated metrics

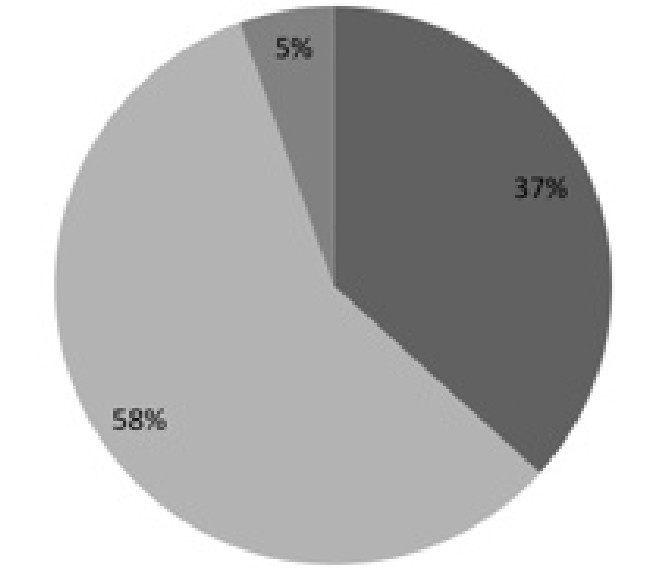

" Static validation $\mathbf{\text { N No validation }}$ Industrial usage

\subsubsection{Innovation measurement frameworks}

We identified 13 existing innovation measurement frameworks reported in literature. We only considered the measurement framework that were proposed by the studies and rejected any other frameworks developed as a tool to prove their concepts. For more detailed information about the selected measurement frameworks, see Appendix I.

\subsection{Interview}

During the study, seven interviews were conducted. Four interviewees had pure industrial experience and remaining three had both academic and industrial experience. All the interviewees were based in Sweden and were conducted in face-to-face meetings. In this study, the interviewees identification information has been anonymized for confidentiality and they are referred to with female pronoun regardless of their actual gender. The abbreviations used to refer to the interviewees (in subsequent sections) and their background information is presented in (Appendix L). The major findings of the interviews are presented below.

\subsubsection{Definitions of innovation}

The definitions from the interviews provided us the industry's perspective of innovation. Having interviewed two different practitioners from each company helped us cover different aspects of innovation and increased validity of the findings. Following are the different definitions given by the interviewees with industrial experience.

- It is to identify and create something new that drives differentiation and generates revenue. It is not just an idea but its implementation into a product that creates value. Sometimes it may not create financial returns but help in driving the brand or customers' perception. It could be a combination of existing things which are utilised in a new area. It can occur during any activity of value chain e.g. in marketing where you can use the existing technology or product but package and position in a totally different way [INT_F].

- Anything that the user did not expect and surprised her. It is not just about fulfilment of needs, innovation is fulfilment of a need that is not known. Or satisfying a known need in a totally new way with substantial benefits [INT_G].

- It comes from identifying and understanding existing and unfulfilled needs and fulfilling them in new ways with time, cost or usage advantage [INT_A].

- When talking about innovation, first thing that comes to mind is inventions, new products, but it has wider meanings. It is really to change something or make something in a better way. So it can be both something you can touch and things that you can do in a better way [INT_B].

- Innovation simply put means something that creates value and is introduced to the market. Value can be as perceived by the user, customer or the producer [INT_C].

- Innovation is adding value. Value can be to customer, user experience, extent to which the user can use to fulfil the intended purpose and internal value (the way of developing product) etc. [INT_D].

\subsubsection{Innovation strategy}

To understand the state of practice in industry it was important to see if innovation is acknowledged at the top level. Having an explicit mention of innovation in the organisational strategy is one such indication.

- The company strategy does not mention innovation. However, it is implicit and understood that to achieve the strategic objective we need to be innovative [INT_F]. 
- Yes, we have a focus on innovation in our strategy [INT_A].

- The new organisation theme mentions 'value added innovation'. It is not very clear what that means for the direction of the company. Perhaps, it still means that no dedicated base research would be conducted [INT_B].

\subsubsection{Innovation process}

Interviewees were asked if they had a defined set of activities related to innovation. Here are the responses we received regarding the presence of innovation process and its description in their respective firms.

- Yes, any employee can contribute an idea to the ideas database, which is then evaluated by the Intellectual Property Rights (IPR) board and selected ideas are patented and if found useful taken up for product development. Employees are rewarded financially and recognised for each idea contribution and successful patent [INT_G].

- Every part of the company once the strategy is communicated develops a list of activities to undertake to achieve the strategic objectives. So, it is not the same for everyone, the diverse types of issues demand different ways of working. Parts of it are ad hoc and parts are streamlined defined steps. We identify an area from the technology strategy (what do we want to do and what is important) and then the IPR board facilitates workshops, we hold seminars and work on competence development. Any employee having an innovative idea has to fill out an idea disclosure form, which is later reviewed for value and potential. For external innovation, we collaborate with start-ups, universities and try to send out the message that we are open for collaboration. Prospective collaborators can submit their ideas to the company, which after review may fund or support development of the ideas into IPR and product features [INT_F].

- No defined process for innovation, usually the new ideas for enhancements come from marketing department [INT_B].

- Advanced systems team, is purposely placed in the sales division for proximity to the customer, they are on the forefront of bringing the first seeds of innovation to build concepts and to see what can be used. These concepts later on move to product development phase where the development is questioned and argued from commercial point of view. Similarly, scouting teams with more experience and extensive domain knowledge look for what could be disruptive new technologies and suggest advanced systems teams the areas to look for new ideas [INT_A].

\subsubsection{Innovation measurement}

The interviewees were also asked about the importance of innovation measurement, presence of measurement initiative and what metrics were currently used. Following are the responses:

- Never thought of measuring innovation itself, rather we should go for measuring the climate for innovation. We introduced a program in the company where employees could spend some time working on an idea of their choice and then we tracked the time spent and number of white papers written [INT_A].

- Innovation measurement is not done probably because of the lack of skills, tradition and understanding why it should be done [INT_B].

- We primarily measure the number of ideas filed, inflow of incoming ideas from external interface and the ideas processed and conversion of ideas and concepts to features in the products. However, measuring innovation is tricky because the important issue is the quality of ideas not just the number [INT_F].

- It is part of the business goals for employees to be creative and we measure this by number of ideas filed. Number of ideas is a very crude measure of innovation as it does not differentiate between the qualities of the ideas [INT_G].

\subsubsection{Feedback about the proposed model}

In the later half of the interview we presented the model in detail, explaining the representation and the components. Interviewees were asked about the correctness, completeness and usefulness of the model. Below we describe briefly the critical comments about the model from the interviewees:

- There are some companies whose business model is not to make products but they do research and develop IPRs and then find the companies who may want to use them and get remuneration for the IPRs. (which does not really mean implementation in the form of a product). More details using the value chain model can be added if we go into details of each of these components in the model [INT_F].

- This model is very open and generic and is the natural way of describing any activity and does cover the related concepts. However, she found a separate feedback and learning loops confusing. For it to be used, the company really needs a mapping of this generic model to the existing structure of the company. Besides the company needs to understand their own context first. They need their own model which everyone not only agrees to but also represents the reality of the business [INT_A].

- First you need to investigate the current practices and see what is missing and what can be improved and the consequences of the model for the company. And see what we already have and perhaps some of the aspects are already in place [INT_B].

- Social capital and gift economy is a very important aspect in the performance measure [INT_G]. 


\subsection{Questionnaire}

In total, we had 145 respondents out of which 104 completed the questionnaire (response rate $71.72 \%$ ). As suggested by Wohlin et al. [41] for data validation before analysis each response was checked. The responses with incorrect demographic information (an indication to non serious participation) and incomplete responses were discarded. Furthermore, three responses were discarded because they were received after the deadline. The remaining 94 responses were used for analysis (as shown in Table 10).

Table 10

Questionnaire respondents

\begin{tabular}{lllll}
\hline \hline $\begin{array}{l}\text { Total } \\
\text { responses }\end{array}$ & $\begin{array}{l}\text { Late } \\
\text { responses }\end{array}$ & Incomplete & Academia & Remaining \\
\hline 145 & 4 & 41 & 6 & 94 \\
\hline \hline
\end{tabular}

\subsubsection{Roles of respondents}

We categorised the respondents into similar roles. Ten different roles were identified from the results as shown in Fig. 8. 25.53\% of the respondents were Software Engineers, $20.21 \%$ of the respondents were Senior Software Engineers and $23.40 \%$ had management or executive responsibilities in their respective firms.

Fig. 8. Number of respondents with each role

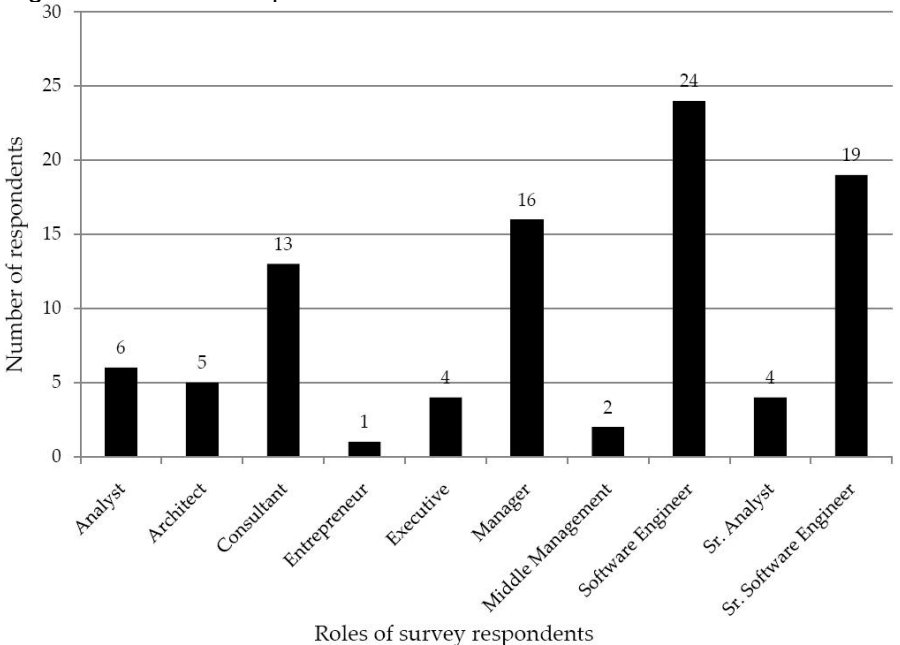

\subsubsection{Job experience of respondents}

The respondents had varying experience in software industry. The respondents were divided into experience ranges as shown in Fig. 9. 34.04\% of respondents had 3 to 6 years of experience and $28.72 \%$ of respondents had 6-9 years of industrial experience.

\subsubsection{Geographic Location}

From the 94 respondents, $42.55 \%$ of them were from Pakistan, $22.34 \%$ were from Indonesia and $12.76 \%$ were
Fig. 9. Experience profile of respondents

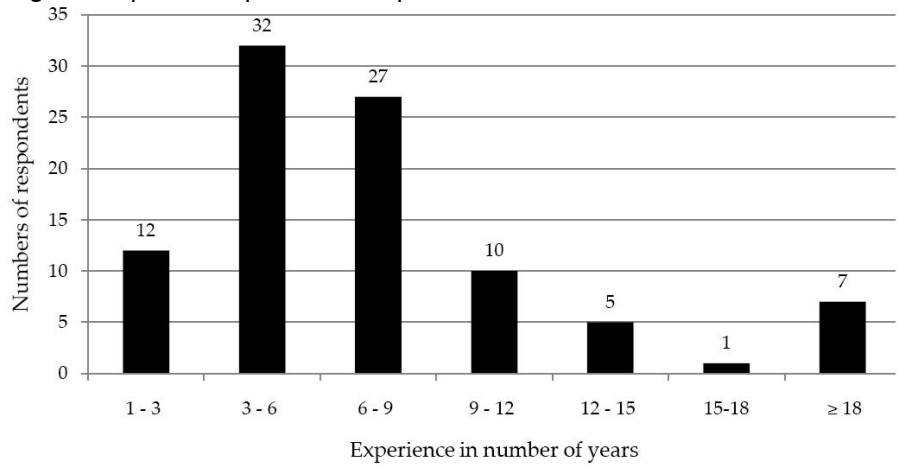

from USA. They came from 68 different firms. The details of percentage of respondents from each country are in Fig. 10.

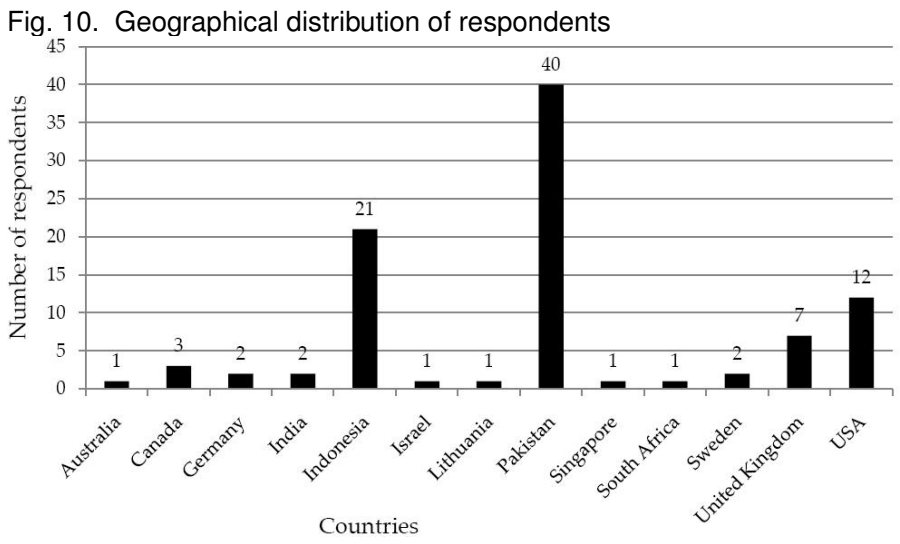

\subsubsection{Firm size of respondents}

The respondents came from a variety of firms of varying sizes (in terms of number of employees). For categorisation based on firm size, the Small and Medium Enterprise (SME) definition was followed [48]. 26.59\% of respondents were from organisations with 500 to 10,000 employees, $24.46 \%$ from 250 to 500 employee firms and $19.14 \%$ from firms with 50 to 250 employees. The distribution of respondents and number of firms in each category are shown in Fig. 11.

Fig. 11. Distribution of respondents to firm size

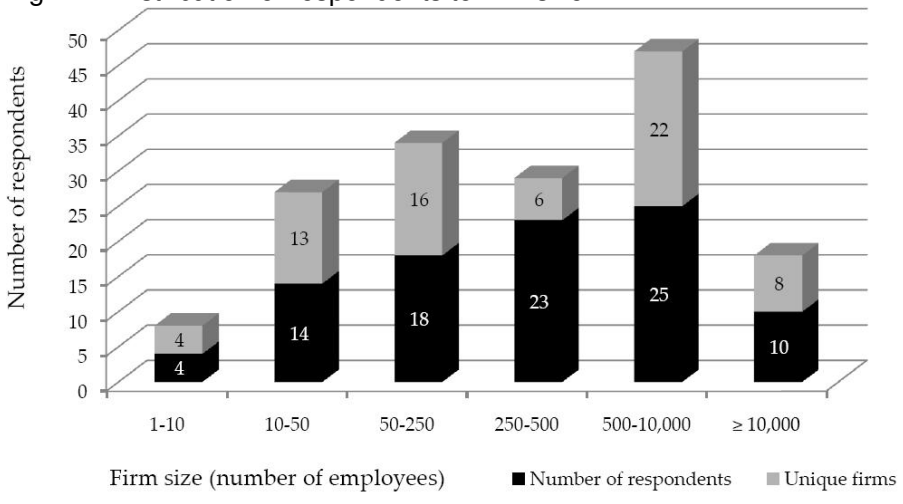




\section{AnAlysis}

In the following sections, two main research questions of the study (RQ1 and RQ2) are answered.

\subsection{RQ1 State of the art of innovation measurement}

\subsubsection{RQ1.1 Definitions of innovation reported in litera- ture}

Innovation in organisational context is distinguished from one time act of brilliance or moment of luck and is defined as an entirely intentional result of actions to bring about perceived changes within the organisation [49]. The concept of innovation was first introduced by Schumpeter in 1934 by differentiating between invention and innovation [50]. Today, there are many different definitions of innovation and each of them emphasises a different aspect of innovation [29]. The two main classifications are innovation as an outcome and as a process. As an outcome innovation may include new products and processes while as a process it refers to a combination of a number of activities that generate innovation output [51].

The 41 definitions found in the literature review (see Appendix B) were analysed and the aspects found are classified in Table 11. These aspects are considered important as these delineate what attributes will be measured when an organisation attempts to measure innovation.

Table 11

Aspects of innovation

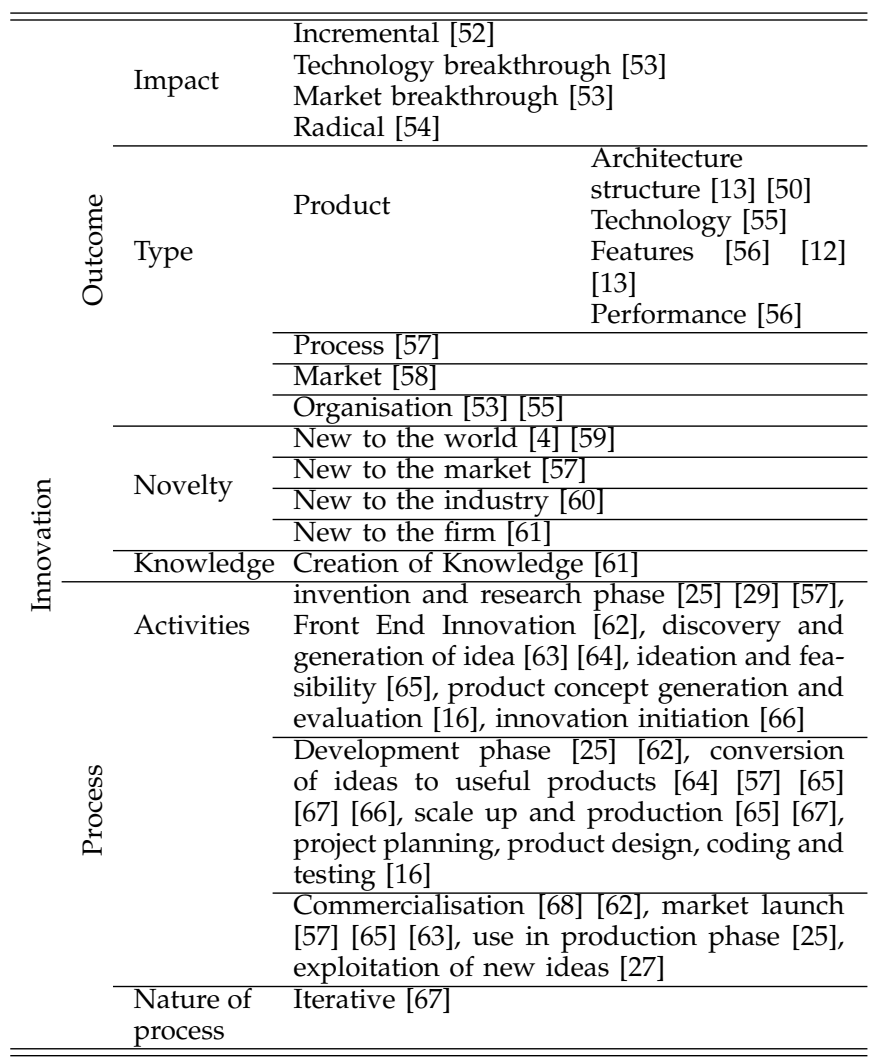

These aspects were used to analyse the coverage of definitions of innovation found in this study and helped identify a comprehensive definition for software industry. Various aspects of innovation and their utility is briefly discussed below.

Impact of innovation: Based on the impact on the market and the change in underlying technology innovation is classified into four major categories:

- Incremental innovations: These are relatively minor changes in technology based on existing platforms which deliver relatively low incremental customer benefits [74] [52].

- Market breakthroughs: These are based on core technology that is similar to existing products but provides substantially higher customer benefits per dollar [74].

- Technological breakthroughs: These innovations adopt a substantially different technology than existing products but do not provide superior customer benefits per dollar [74].

- Radical innovations: It also is referred as disruptive innovations which introduce first time features or exceptional performance [56] [12]. It uses a substantially different technology [75] [74] at a cost that transforms existing or creates new markets [12] to delivers a novel utility experience to customer [75].

Continual reliance on old technology will jeopardise the market position of a firm [56]. Therefore, organisations must seek radical innovation as it disrupts former key players and creates entirely new business practices or markets with significant societal impact [12] [76]. The decision to focus on radical or incremental innovations has important implications for innovation management [77]. For example it would influence what sources of new ideas are focused on and given priority. An organisation looking for incremental improvements may conduct focus groups and surveys with customers. However, these are poor techniques to predict significantly new products to meet customer needs [78]. A better approach to solve this problem is to study the use of the products and observe the practical problems they encounter [78]. This point is also mentioned by one interviewee 'It is important to spend more time with the customer and the end users observing the practical issues they are facing'.

Types of innovation: There are four types of innovation:

- Product innovation: It refers to creation and introduction of new (technologically new or significantly improved) products which are different from existing products [4] [75] [86] [55] [80] [58] [87] [25].

- Process innovation: It refers to implementation of a new design, analysis or development method which changes the way how products are created [4] [58] [87] [25].

- Market innovation: It refers to implementation of 
new or significantly modified marketing methods, strategies and concepts in product design or packaging, placement, promotion or pricing [4] [87]. It includes opening up new market opportunities, position innovations (including changes in the context in which the products are introduced) and implementation of new or significantly modified marketing strategies [58] [25].

- Organisation innovation: It refers to implementation of a new organisational method in the firm's business practices, workplace organisation or external relations [4]. It includes changes in the architecture of production and accounts for innovations in management structure, corporate governance, financial systems or employees remuneration system [55] [25].

Degree of novelty of innovations: This aspect of innovations has differential implications for organisation growth [76]. It is also useful to identify developers and adaptors of innovation which can differentiate market leaders from followers [4]. Based on the perspectives important to the firm, there are four types of innovation:

- New to the firm: This is the minimum level of novelty of innovation that it must be new to firm. It is defined as the adoption of an idea, practice or behaviour whether a system, policy, program, device, process, product, technology or administrative practice that is new to the adopting organisation [55] [80] [59] [81] [82] [83].

- New to the market: When the firm is the first to introduce the innovation to its market [4].

- New to the world: These innovations imply a greater degree of novelty than new to the market and include innovations first introduced by the firm to all markets and industries, domestic and international [4].

- New to the industry: These innovations are new to the firm's industry [76] [67] [60].

- Knowledge view: Innovation is seen as creation of knowledge by application, recombination or extension of existing knowledge [84] [61]. It can be understood as a process in which organisations' knowledgeable and creative people define and frame problems and then develop new knowledge to understand and solve them [44] [85].

Innovation activities: Schumpeter's definition stresses on the novelty in innovation [29]. While invention is the first occurrence of ideas, innovation refers to their first economic utilisation or commercialisation [50] [69] and successful launch to market as products [70]. This idea still dominates the definitions and the necessity of commercialisation for innovation is emphasised. Innovation is described as the discovery of new ideas (with value in marketplace [71]) and successful exploitation through commercialisation of these discoveries [5] [25] [72] [73]. It is the tendency to not only implement products but also to introduce them to the market [15]. The situations where the innovation relates to an internal activity like the improvement in development process, the phrase commercialisation can be substituted with 'implementation' [5].

Nature of process : Innovation is a iterative process [67]. In this process idea generation or adoption, development of products, and introduction of products to marketplace and implementation of processes in organisation are the major activities [54] [64] [57] [63]. It could be initiated by the perception of new market or opportunity leading to development of products using competencies inside and outside the organisation [47] to strive for commercial success [67]. Other definitions focus on where the ideas for innovation are generated, like Wakasugi et al. [79] suggests that innovations are generated as products move through product life-cycle processes from research laboratory to the factory.

\subsubsection{RQ1.2 Determinants of innovation}

Out of 23 studies conducted in software related context, there are only six studies that identified the determinants of innovation. However, this does not mean that determinants found in other contexts are not applicable in software industry. The following discussion is based on the findings of determinants studied in software context.

Study by Akman et al. [3] found that customer orientation is the one of the important factors that significantly affects the innovation capability. Customer orientation describes the firm's behaviour to understand and create high value for the fulfilment of customers' need. He argued that by more focusing on customers, software firms will be able to improve their innovation capability since customers' needs and wants are the source of innovative ideas. The same finding is also mentioned by Paladino [88] and Voss [89]. Therefore, Paladino suggests that managers should look for a new strategy to fulfil the market needs although it is difficult to achieve [89]. In this situation, futurity - one dimension of innovation strategy, will help organisation preparing for future conditions [3]. Organisation should not focus on current needs but also future needs and this can be done when organisation maintains a good relationship with customers.

Inter-functional co-ordination is another factor that has significant effect on innovative capability [3]. Good and integrated co-ordination among all departments can promote an effective knowledge transfer inside the firm. It allows sharing of innovative ideas are shared among the employees and transformed into innovation outcome. However, according to Voss [89] this happens only if the customers know the problems and the technology is available inside the organisation. Otherwise, organisation needs to communicate with external side to 'better identification of potential market and, hence, to commercial success' [89]. 
To support inter-functional co-ordination, study by Romijn [13] found that for small high tech firms, specialised knowledge and experience in science and technology should be in place. This is more important than technical or general managerial skills. Therefore, startups need at least two important things, access to universities or other research institutes to train the staffs with lower cost and R\&D funding to maintain innovation learning to achieve technological excellence.

On the other hand, competitor orientation does not significantly affect the innovation capability [3]. In software industry, competitors are treated as partners rather than as rivals [3]. Software firms tend to collaborate in software development with competitors. This usually happens for SMEs to survive against large firms.Therefore, being aggressive - by allocating more resources to improve market position will not improve innovation capability. The same effect also happens when organisation becomes defensive, by making incremental innovation on current products [3].

Different from other industry, technology orientation has negative impact in software industry [3]. Software development highly depends on the skilled and creative persons rather than technology. This result echoed Brooks' statement when he said that 'software construction is a creative process' [90]. Moreover, Brooks argued that no silver bullet can solve 'the essential difficulties in the nature of software' [90]. This creative work should be supported by creative climate e.g. challenging work, freedom and group support [91]. Creative climate is more important for software team in producing creative outputs [91].

In hardware technology as in manufacturing industry, technology breakthrough has improved the productivity and reliability of computer hardware. In software industry, analysis and design has become the crucial phase in software development [90] [89]. A good software design can be reused in other projects and will shorten the development period and the cost as well. Hence, this development aspect needs to be managed properly.

Study by Gumusluǒlu et al. [15] found that transformational leadership also has positive effect on organisation innovation. Transformational leaders inspire the organisation to innovate by encouraging the employees to generate creative ideas and as a result ensure the market success of innovations [15]. The study found that the positive influence is shown on incremental innovation in developmental work. When this proactive behaviour is part of innovation strategy, the organisations are more flexible to facilitate innovations [3]. This proactive strategy enables the organisation to actively behave according to market trends.

The importance of product champion (in software context) was introduced by Voss [89]. Champions enthusiastically encourage and promote innovation during the project. They are the individuals with a strong reputation, knowledge of the business, possess good facilitating skills and have the authority to bring change in the organisation [24] [89]. They are responsible for the entire innovation process and play their role in development stage to help initiate the project and stay involved in the commercialisation stage as well [24] [89].

Voss [89] and Akman et al. [3] also found that innovation should be part of organisation's strategy, plan and culture. Once innovation has become a daily habit inside the organisation, the innovation process will also become more effective [89].

\subsubsection{RQ1.3 Metrics for innovation measurement}

The 275 metrics identified in this study were categorised into following categories based on the aspect they are used to measure.

- Determinants (Appendix C)

- Inputs (Appendix H)

- Outputs (Appendix G)

- Performance (Appendix G)

- Process (Appendix F)

48 out of 275 metrics were reported in studies related to software industry (shown in Appendix E). Furthermore, the study investigated the evidence of empirical validation presented in Section 5.1.7 and Fig. 7. The data-extraction form (shown in Table 7) was designed to find details about the individual metrics found in the study. However, it was found the important aspects like the scale types, attributes measured, collection method, computation and interpretation guidelines were missing in some of the studies. This may limit the practical use of metrics found in them.

\subsubsection{RQ1.4 Existing innovation measurement models}

Most of the existing frameworks found in this study are more focused on measuring the technological aspect of innovation. There are eight frameworks which are intended to measure technical capability i.e. [92], [93], [94], [95], [47], [96], [97], [98]. However, according to Oslo manual [4], technology is only one aspect of innovation. Thus these frameworks cannot be used to measure overall innovation which includes non-technological aspect as well. For this reason, in the latest version of the manual, OECD removed the term technology in the definition and introduced two new types of innovation: marketing and organisation.

One framework focuses on product innovation ([99]) while the remaining do not clearly specify the measurement area. There is a lack of empirical validation since only the study by Byrne [100] reports the usage of six sigma in industry. The study itself focuses on radical innovations.

Out of 13 frameworks, index of innovativeness [98] is the only framework that focuses on software firms. The framework was based on six metrics adapted from Oslo manual. Using the data from these metrics, index of innovativeness was calculated. Based on this number, the firms can be plotted into three dimensions to see the relative position of the firms in a particular geographic 
market served by them. However, this framework did not take into consideration organisational and marketing innovations.

Surprisingly, there was only one framework that has been validated in industry, technical audit framework by Chiesa [94] (see Appendix I). This might be the reason why this framework has been cited by other technical audit-based frameworks e.g. [93], [47], [97]. Most of the remaining studies collected data from industry (through survey or case studies) and performed statistical analysis to evaluate their frameworks.

\subsection{RQ2 State-of-the-practice in innovation mea- surement}

For ease of analysis, the respondents were grouped into major classes based on their reported roles. This classification was very intuitive and straightforward as shown in Table 12.

Table 12

Questionnaire respondents' roles and abstraction

\begin{tabular}{ll}
\hline \hline Category & Roles \\
\hline Executives & Only executives \\
Senior Management & Executives \& Middle management \\
Middle Management & Head of departments \\
Managers & Project and product management \\
Technical & Software Engineers, Senior (Sr.). \\
& Software Engineers, Analyst, Sr. An- \\
& alyst, Consultants \\
Non Technology focused & Executives, Entrepreneur, Middle \\
& Management, Managers \\
\hline \hline
\end{tabular}

\subsubsection{RQ2.1 Definitions of innovation}

In general, all respondents agreed that idea generation is the most important activities of innovation and commercialisation is the least. When the data was analysed with different roles of the respondents new trends appear (see Fig. 12).

Fig. 12. Questionnaire responses on what constitutes innovation

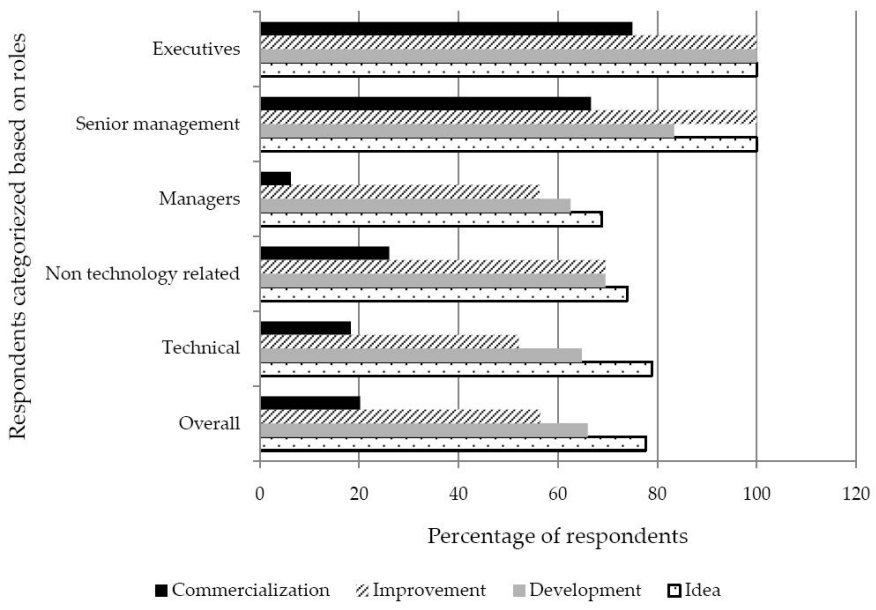

Based on the respondents roles, it can be seen that respondents in technical roles consider that innovation consist of idea generation and new development while respondents in higher managerial roles think that idea generation and improvement in existing product are equally important. This means that respondents in technical role more focus on technological breakthrough. The main reason for this was as the nature of its role, technical staffs more concern about technical aspects rather than commercialisation.

On the other hand, $66.67 \%$ of senior management and $75 \%$ of executives consider commercialisation an important constituent of innovation in contrast with only $18.30 \%$ of technical respondents. This was an expected trend as higher management is more concerned about business objectives and financial success of the company. This is also in line with the importance of commercialisation found in systematic literature review.

Respondents in higher management roles also recognised the presence of incremental innovation. This was also understandable since radical innovation has higher financial risk than incremental. Therefore, focusing on current customers is needed to sustain the long-term business relationship.

Types of innovation: The respondents with technical roles have a strong inclination on products innovation followed by process, market and organisation (see Fig. 13). The main reason for this is that practitioners with technical perspective are mainly involved with product and process development so they consider innovations only in this limited perspective. On the other hand, the respondents with management and executive roles prefer process innovations over product innovation. Furthermore, as they have a business perspective, they considerably emphasise the 'Market' followed by 'Organisational' innovations .

Fig. 13. Questionnaire responses on types of innovation

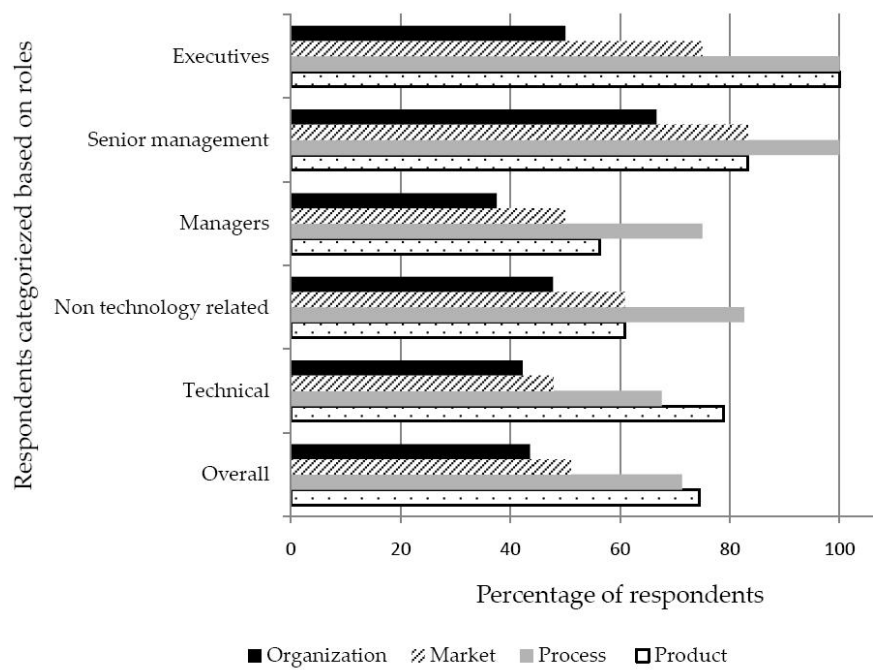




\subsubsection{RQ2.2 Importance of innovation measurement}

The respondents were almost unanimous on importance of innovation measurement (see Fig. 14). This also validates the finding of systematic review where innovation measurement has been extensively emphasised and are inline with the findings by BCG survey [22].

Innovation strategy and measurement: Only $42.55 \%$ of respondents said that they are aware of an explicit innovation strategy for the organisation (Fig. 15). Similarly, only $35.10 \%$ respondents said that their organisation measures innovation and $40.42 \%$ were sure of no innovation measurements in their organisation $13.82 \%$ and $24.46 \%$ expressed unawareness of an explicit strategy or measurement program in the organisation. One reason for such high unawareness is that strategies are often not shared with the entire organisation. Therefore, in case of technical resources such unawareness can be expected about strategies and measurement programs. Out of the 13 respondents unaware of absence or presence of such a strategy 12 were technical respondents. Similarly, out of 23 respondents who were unsure about innovation measurement practice 19 were technical and 4 were managers.

Fig. 14. Questionnaire response on importance of innovation measurement

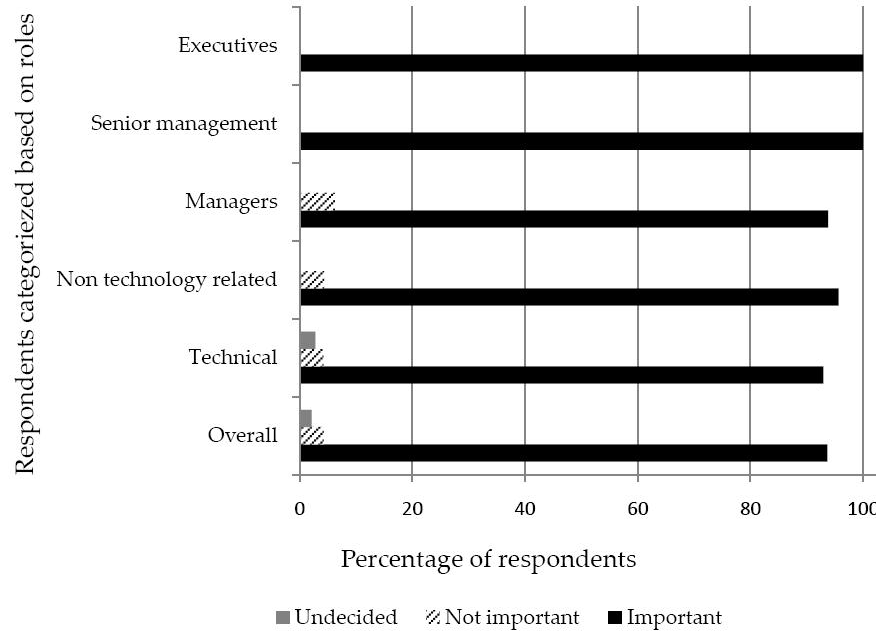

Fig. 15. Questionnaire results on innovation strategy and measurement

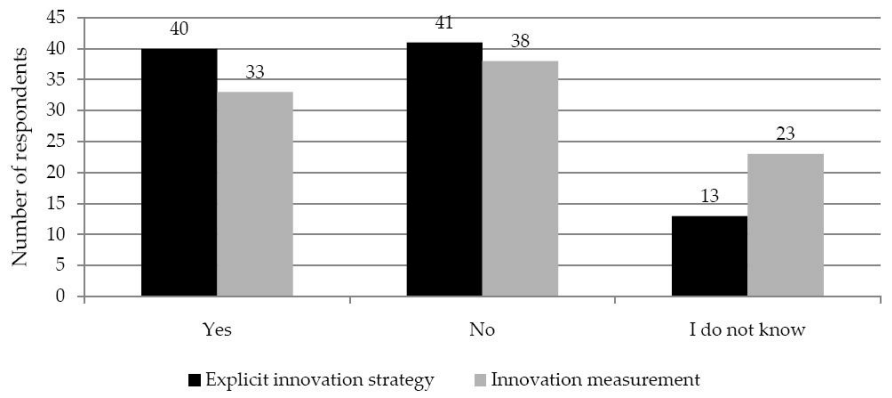

24 respondents who were aware of an explicit strategy on innovation also reported an innovation measurement program in their organisation. Similarly, 27 respondents who said there is no explicit strategy reported that they do not engage in innovation measurement (see Table 13). This would be expected, as an organisation with explicit emphasis on innovation is more likely to use measurements for innovation management and vice versa. It was interesting to see six respondents who said their organisations do not have an innovation strategy but claimed they do innovation measurement. One possible explanation is the fact that employees are unaware of the strategies in the organisation while measurement program(s) affect everyone when it is operational. Another possible explanation for this result is that the organisation measures aspects related to innovation but not under a defined strategy.

Table 13

Innovation strategy \& measurement

\begin{tabular}{lll}
\hline \hline & Measurement & $\begin{array}{l}\text { No } \\
\text { measurement }\end{array}$ \\
\hline Explicit strategy & 24 & 5 \\
No explicit strategy & 6 & 27 \\
\hline \hline
\end{tabular}

Organisation size, innovation strategy $\mathcal{E}$ measurement: The respondents from firms with 10 to 10000 employees showed lack of innovation strategy (see Fig. 16). However, the results are interesting at both extremes of employee size. The smaller firms with less than 10 employees are most likely not to have an explicit strategy but $75 \%$ of respondents in this range reported having a strategy. Since, we had only four participants from organisations with less than ten employees the result is inconclusive. On the other hand as expected $60 \%$ of employees with firm size over 10000 employees reported explicit innovation strategy.

Fig. 16. Innovation strategy and firm size

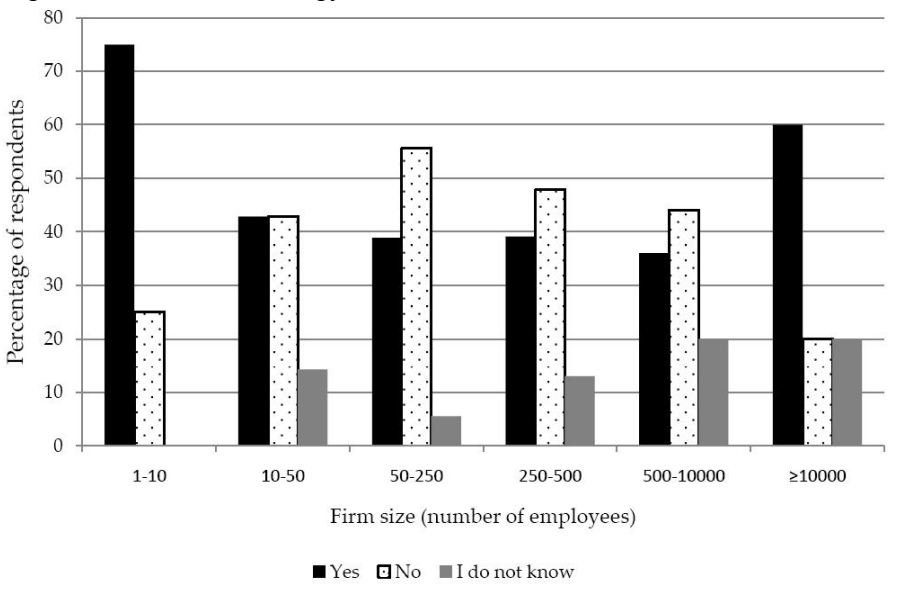

The trend in responses regarding innovation measurement is very similar to the innovation strategy (see Fig. 17). From the questionnaire results (shown in Fig. 14, Fig. 15 and Fig. 16) we can see that practice of innovation 
measurement is driven by the existence of an innovation strategy.

Fig. 17. Innovation measurement and firm size

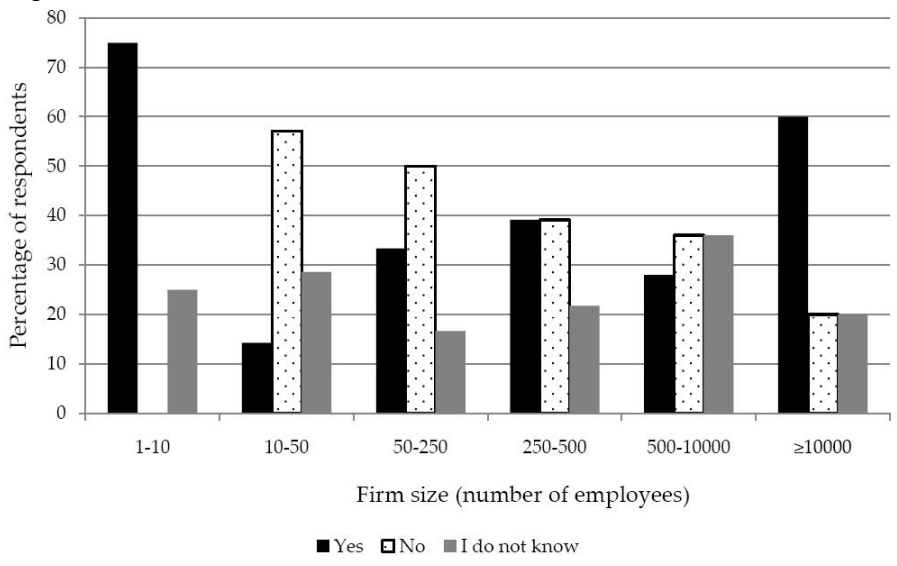

\subsubsection{RQ2.3 Metrics used in measuring innovation}

Subsets of metrics from the findings of systematic review covering key aspects of innovation measurement were put in the questionnaire. The respondents were grouped on the basis of the company they belonged. We had a total of 28 unique firms who do measure innovation. One response was ignored since 8 other respondents from the same company at same and different roles reported that there is no innovation measurement in their organisation. The results are shown in Fig. 18. The abbreviations used in Fig. 18 are explained in Table 14.

Fig. 18. Metrics used in the companies

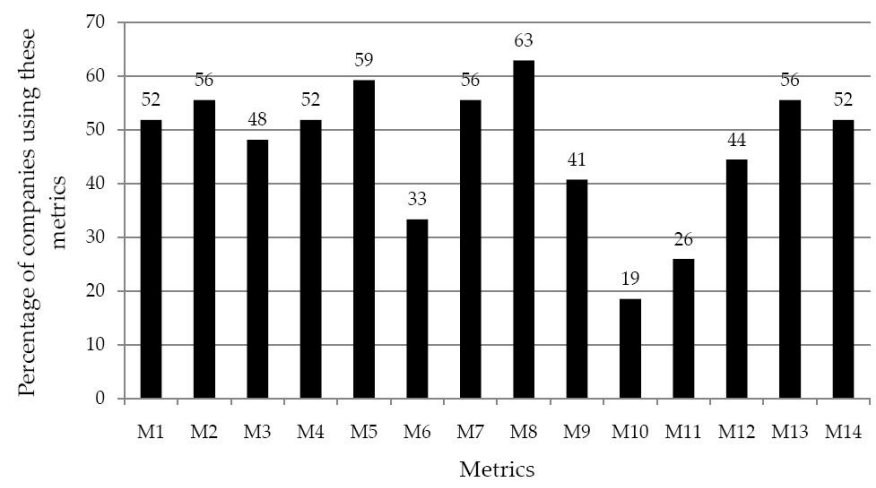

Maximum usage was reported for metric M8 followed by M5, M2 and M13. Whereas, M10 followed by M11 and M6 were the least used metrics. This shows an emphasis on measuring inputs and output of innovation in terms of resources spent on innovation and results in the form of improvements in process and product and improved product quality. This result was expected as the factors like environment and commitment which are necessary to create an environment conducive to innovation are often ignored.

Satisfaction from metrics used: Unlike the expected results as that of the existing surveys e.g. BCG survey
Table 14

Metrics used in questionnaire

\begin{tabular}{ll}
\hline \hline Abbreviation & Details \\
\hline M1 & Percentage of sales spent on R\&D \\
M2 & Percentage of sales spent on new projects \\
M3 & $\begin{array}{l}\text { Percentage of employees dedicated to R\&D activ- } \\
\text { ities }\end{array}$ \\
M4 & Number of new ideas generated \\
M5 & $\begin{array}{l}\text { Number of ideas converted successfully to prod- } \\
\text { ucts }\end{array}$ \\
M6 & Time taken in converting an idea to a product or \\
process \\
M7 & Number of new products \\
M8 & Number of improvements in existing products \\
M9 & Number of intellectual property rights \\
M10 & Creative environment (Subjective assessment) \\
M11 & Presence of innovation champions \\
M12 & Percentage of new product sales to total sales \\
M13 & Improvement in product quality as a result of \\
innovation \\
M14 & Improvement of customer satisfaction as a result \\
& of innovation \\
\hline
\end{tabular}

[22], the questionnaire respondents expressed satisfaction with the metrics that they currently use to measure innovation (see Fig.19). It seems that these metrics give them enough control and visibility to manage innovation. However, since there were only 6 non-technical respondents who said that their organizations measure innovation we do not have enough sample size to conclude anything here. One of the respondents who expressed dissatisfaction, said that the metrics are currently calculated in 'Silos' without a defined governing process. This hinders organisation wide sharing of metrics about innovation which may otherwise prove massively useful for business teams. Another dissatisfied respondent mentioned that the cycle time (idea to product) and measuring product can be useful metrics. However, they are not currently collected in the organisation.

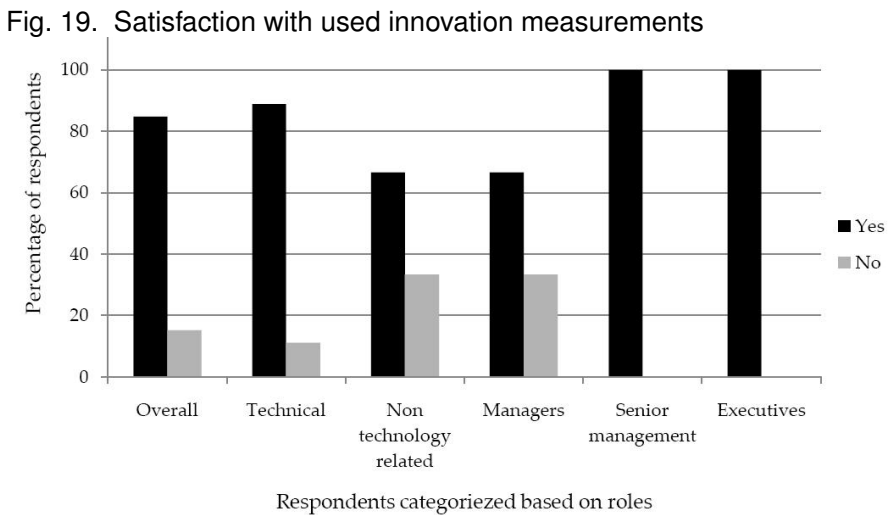

\subsubsection{RQ2.4 Framework used for innovation measure- ment}

The importance of innovation measurement initiative has been recognised in software industry. This information is given by 32 respondents from 27 unique 
firms who said that their organisation does measure innovation. Of these firms $74.07 \%$ of the firms do not use any measurement framework. One respondent mentioned use of a survey for innovation evaluation in the company. Another respondent mentioned use of a framework but did not share any details because it is company confidential.

\subsubsection{RQ2.5 Challenges of innovation measurement}

Based on systematic review, we identified five common challenges of innovation measurement in other domains. We asked the respondents whether the same challenges also existed in their context. The following section discusses the results of the questionnaire:

- Lack of recognition of the importance of innovation measurement: Respondents from firms smaller than 10,000 employees generally agree to the statement that innovation measurement importance is not recognised. On the contrary larger organisations which are already undertaking innovation measurements (as found in systematic review and this questionnaire see Fig. 20) do not consider that there is a lack of acknowledgement of innovation measurement importance.

Fig. 20. Lack of recognition of importance of innovation measurement

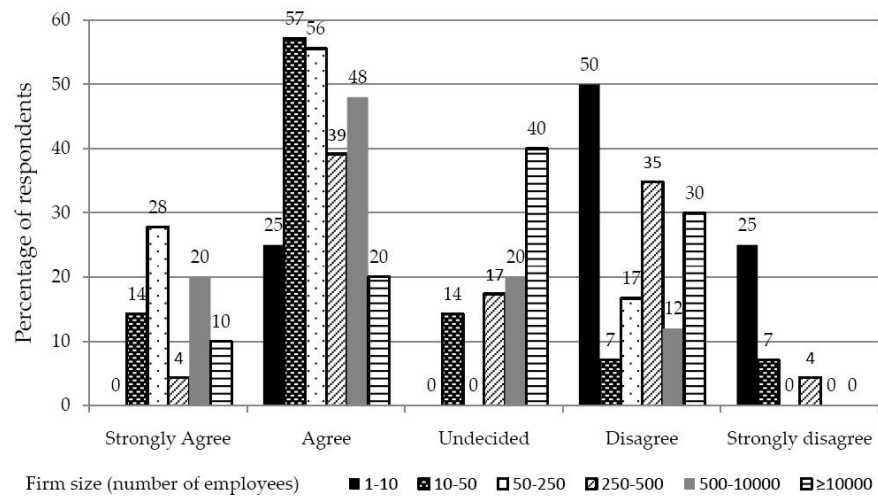

- Lack of consistent definition of innovation: With exception of firms with 1-10 employees (see Fig. 21), there seems to be a consensus that there is a lack of consistent definition and it hinders the innovation measurement. This result is consistent with the findings of the SLR where 41 definitions were found. For larger organisations the issue is lack of consistent definition of innovation, metrics and guidelines. Whereas for smaller firms the issues also include lack of recognition that innovation measurement is useful.

- Lack of metrics for innovation measurement: All respondents tend to agree upon this issue that there is a lack of metrics that is hindering organisations to pursue innovation measurement (see Fig. 22).

- Lack of guidelines and framework: Except for respondents from 1-10 employee firms, majority of respondents agree that lack of guidelines and framework
Fig. 21. Lack of consistent definition for innovation

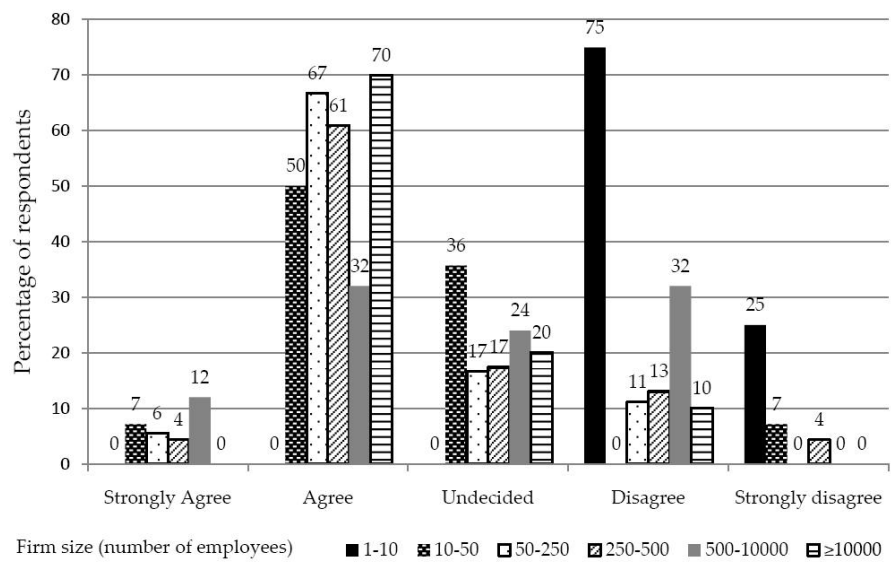

Fig. 22. Lack of metrics for innovation measurement

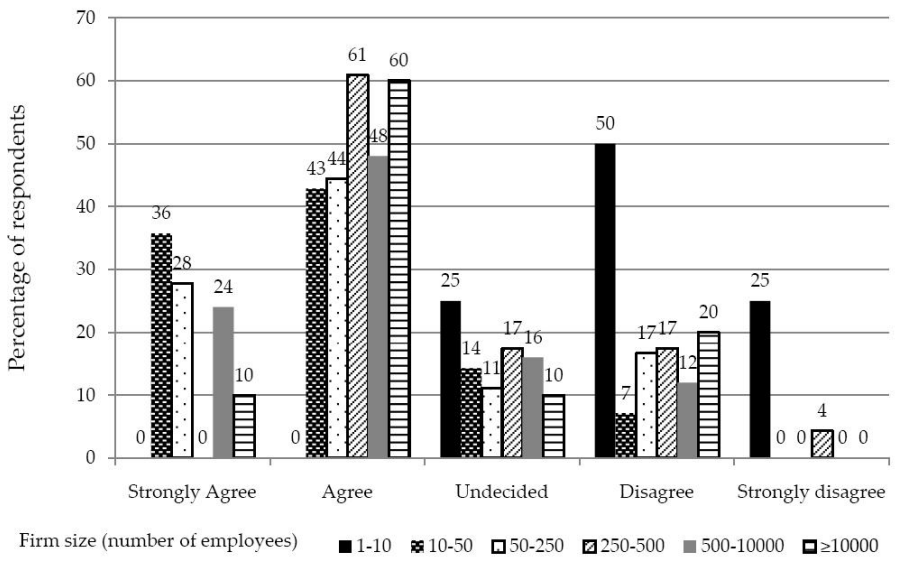

is a main challenge for innovation measurement in their firm (see Fig. 23).

Fig. 23. Lack of guidelines and framework for innovation measurement

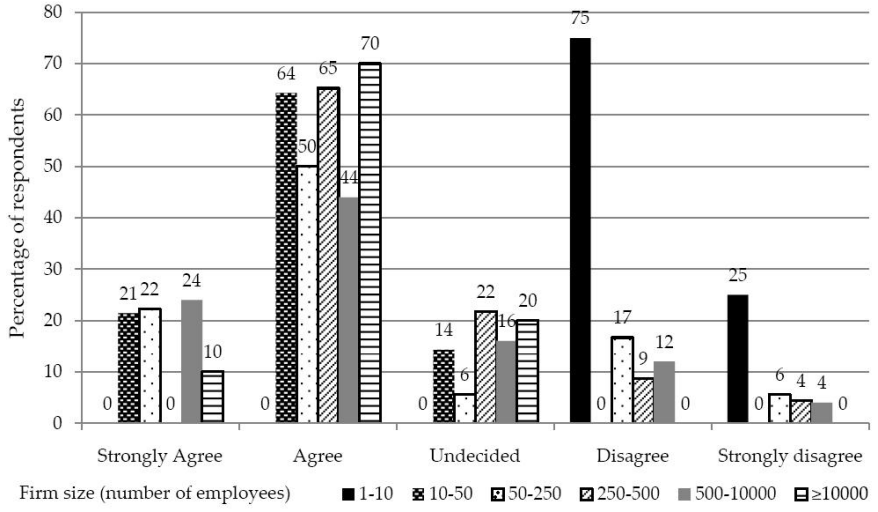

- Cost associated with innovation measurement: Like any measurement program, innovation measurement would also require an undertaking from the company in terms of financial, time and human resources. The respondents were asked to express their opinion if the cost associated with a measurement program is hindering their firm from adopting 
it. However, looking at the graph in Fig. 24 we can draw no conclusion as respondents from all firm sizes tend to be unsure whether the cost associated with the innovation measurement program is a challenge.

Fig. 24. Cost of innovation measurement program

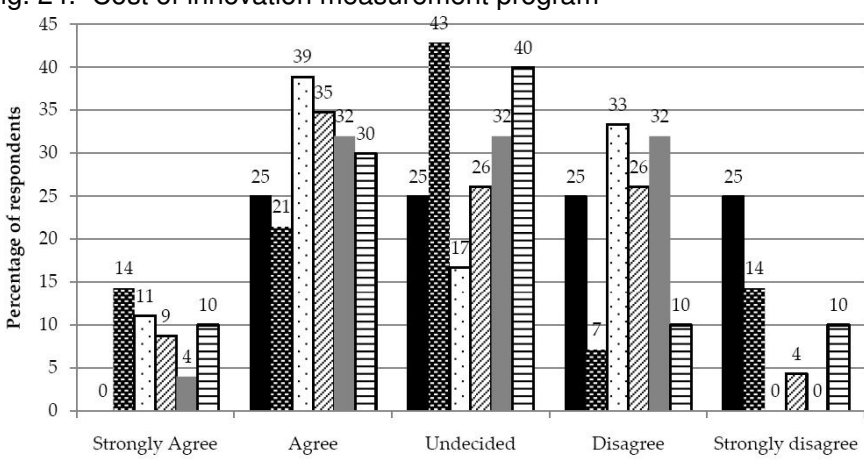

Firm size (number of employees)

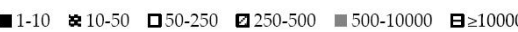

\section{Discussions}

\subsection{Definition of innovation for software industry}

We now focus on perception of innovation based on the definitions by questionnaire respondents, interviewees and systematic literature review.

While defining innovation, one interviewee [INT_A] emphasised the purposefulness of innovation. It must be targeted towards 'identifying and understanding existing and unfulfilled needs and fulfilling them in new ways with time, cost or usage advantage'. She also mentioned that commercialisation is an important requirement for something to qualify as innovation.

Another interviewee [INT_B] described innovation as 'First thing that comes to mind is invention and new products but innovation has broader meanings. It means changing something or making something in a better way'. She further stressed the tangible and intangible nature of innovations (in this case process and product innovations) when she said 'It can be both something you can touch and a better way of doing things'. She did not mention the importance of commercialisation as a criteria to define innovation as she said 'Sure if you are working in a company you want to make money'.

One academic [INT_C] also emphasised that 'Innovation is adding value, and value could be customer value, user experience, internal value etc.' According to her, innovation means 'delivering something that creates new value, the value could be perceived by customer, user or producer'. She highlighted the importance of commercialisation for innovation. It can be noted here that there is some congruence between all of these definitions. The results of the systematic review and interviews are also consistent on dimension of novelty of innovation. Anything that is new to the firm qualifies as innovation.
The academics and practitioners (with higher management experience) perceive innovation at much broader level by using abstract concepts like value creation and need fulfilment. They look at the purpose and goal to define what may be considered as innovation. While the practitioner with $R \& D$ management experience talked about concrete innovation types and mostly stressed on new and improved processes and products. Generally there is a consensus that for something to be considered innovation, commercialisation is very important. This is also consistent with the view of innovation found in the systematic review. Commercialisation which means introduction of products to market and implementation of processes, organisational and marketing methods in actual use is an important feature of innovation [4].

We saw in the questionnaire results that only $18 \%$ of technical resources considered commercialisation an important determinant of innovation (refers to Fig. 12). According to one of the interviewees [INT_D], there are many confounding factors which may affect the successful commercialisation of new products. She argued that with a strong brand, extensive marketing and large market share an organisation might manage to sell a 'bad innovation'. On the contrary, without these resources, organisation might fail to sell a 'good innovation'. However, we think that by differentiating between commercialisation (introduction or implementation) and performance of innovation we can resolve this disagreement.

Identifying a comprehensive innovation definition is important as in questionnaire we found that lack of a consistent innovation definition is considered a challenge Fig. 21. This is also consistent with the findings of the survey where respondents gave different definitions focusing on different aspects. One practitioner mentioned how the perception of innovation differs across the departments of the same organisation [INT_A].

Therefore, among the definitions given or used by the primary studies in this literature review (as shown in Appendix F) we analysed each definition for coverage against the identified aspects of innovation in Table 15. Two definitions of innovation by Crossan et al. [29] and Organisation for Economic Co-operation and Development (OECD) Oslo manual [4] stood out. According to OECD [4] 'An innovation is the implementation of a new or significantly improved product (good or service), or process, a new marketing method, or a new organisational method in business practices, workplace organisation or external relations'. Crossan et al. [29] modified the definition given by European Commission's Green Paper of Innovation(1995, pp. 1-2) 'Innovation is: production or adoption, assimilation, and exploitation of a value-added novelty in economic and social spheres; renewal and enlargement of products, services, and markets; development of new methods of production; and establishment of new management systems. It is both a process and an outcome'. This thesis uses the definition of innovation from Crossan et. al [29] 
for its comprehensive coverage of the identified aspects of innovation in literature and interviews.

\subsection{Importance of innovation measurement}

Although, there was disagreement on what is currently measured by the organisations and what interviewees thought should be measured but there was agreement on importance of innovation measurement. Similarly, the respondents of questionnaire regardless of their roles in the company agreed that innovation measurement is important 14. The number of publications which are increasing every year as shown in Fig. 4 and the emphasis in the literature also indicates that it is considered equally important in academia. However, when we look at the presence of an explicit strategy for innovation, actual measurement program and innovation process (these aspects indirectly indicate the importance given to the innovation measurement in practice), the reality is very different. More respondents indicated lack of an explicit strategy and measurement program in their organisation. The same scenario was found in the interviews where all four industry practitioners reported either a lack of innovation strategy and measurement program or expressed dissatisfaction with the current practice. Similarly, one firm interviewed had no innovation process and the practitioners from the other firm expressed dissatisfaction regarding process being followed in their organisation. Thus we can conclude that although there a growing consensus on importance of innovation measurement in both industry and academia but the practice is still lagging behind. We look at some of the challenges inhibiting the innovation measurement practice in Section 7.4.

\subsection{Determinants of innovation in software industry}

Most of our literature review results suggest that the existence of innovation strategy will help organisations in promoting innovation culture. However, our findings from interview and questionnaire suggest that the importance of innovation strategy in software industry is not significant. Only $42.55 \%$ of respondents are aware of the explicit strategy on innovation in their organisation (see Fig. 15). This is in-line with what one of the interviewee said about her department that all employees have to be innovative to solve the problem, not because of the strategy, but for the sake of the project [INT_B]. She knows that her company has a strategy related to innovation, but does not consider as main driver for innovation.

The importance of innovation strategy to create a creative climate is also not recognised in software industry. One of the interviewee argued that organisation behaviour is not necessarily determined by the top-down approach but also bottom-up, where the employees actively change their day-to-day behaviour [INT_G].

\subsection{Challenges in measurement of innovation in software industry}

The following section discusses the challenges of innovation measurement in software industry and the extent to which this study alleviates them.

\subsubsection{Lack of a consistent definition of innovation}

This issue has been identified in the systematic review, interview and questionnaire. Definition is fundamental as it affects the measurement program and helps provide a common understanding. This improves communication and understand-ability between different stakeholders involved in innovation measurement. With the comprehensive definition (as it covers all the aspects identified in the literature review and the interviews) identified in Section 7.1 proposed for use in software industry we hope to address this issue.

\subsubsection{Lack of metrics}

This issue was identified in the questionnaire conducted in this study. However, looking at the large number of metrics found in the literature review we think that there could be three explanations for this difference between state-of-the-art and state-of-the-practice:

- Lack of awareness of appropriate metrics: There were no studies which have aggregated the existing metrics this could explain the ignorance about the existence of appropriate metrics.

- Lack of validation of metrics: Only $37 \%$ of the metrics found in the literature (as shown in Fig. 7) have been subjected to some static validation and there have been no industry trials or dynamic validation. This lack of empirical validation may also be a reason why industry is hesitant in adopting the suggested metrics.

- Interpretation: As innovation is not fully understood, it is hard to interpret the values of the metrics. Therefore organisations often resort to only measuring the performance of innovation (e.g revenue generated). For example measuring the number of training that employees had during the past year gives an indication of whether you are investing to promote innovation. However, it does not give information about the innovation capability.

By conducting the systematic review and aggregating the existing measure we attempt to facilitate tackling this issue. Furthermore, this study investigated and identified a lack of validation and thus identified a direction for future research.

\subsubsection{Lack of frameworks for innovation measurement}

According to Mendonça et al. [101], measurement frameworks consists of 'a set of related metrics, data collection mechanism and data uses inside a software organisation'. Moreover, measurement should be based on goals and models [102]. Since there is no agreement on what innovation is, there is also no agreement on what metrics 
should be collected. One interviewee [INT_A] mentioned that there is no consensus as to what constitutes innovation within the same organisation. Moreover, innovation is a broader term and some aspects might be difficult to measure. Even if the metrics have been defined, the next issue is whether the metrics are reliable and give information about the innovativeness of the organisation.

Although, we found only one innovation measurement model that is proposed in software context (refers to Section 6.1.4), the existence of such frameworks has been recognised in industry. Based on the questionnaire results, we found that some innovation measurement frameworks have been used in $25.93 \%$ of the companies (refer to Section 6.2.4). However, it seems that there is no standard framework to measure innovation, it is subject to the company and often confidential. We think that any measurement framework like GQM, PSM and Balance scorecard etc. can be used. Some of the aspects that were missing were a comprehensive innovation definition, model and metrics for innovation measurement. By contributing in these three aspects we hope to improve the current practice (an example scenario of use of the proposed model with a well established measurement framework is given in Section 8.3.

\subsubsection{Challenges in existing innovation metrics}

There are a number of different metrics which were found in this literature review. These metrics can be classified into following major categories:

- R\&D-based measures

- Revenue-based measures

- IPR-based measures

- Innovation counts-based measures

- Process measures

- Survey measures

- Investment-based measures

Each of these proxies of innovation has relative strengths and weaknesses in terms of coverage of type of innovation [25]. For example, R\&D is just one of the inputs these metrics do not cover the non $R \& D$ inputs like market analysis and training of employees etc. [103]. Detailed information about the coverage is shown in Table 15.

RED-based measures: There is a lot of focus in traditional industries on $\mathrm{R} \& \mathrm{D}$ as input and driver for innovation in some cases. However, dedicated research units is a luxury that is not available to SMEs [31]. This was also noticed in interviews e.g. the 'scouting teams responsible for looking out for new technologies and ideas did this as an additional task in their job role' [INT_A]. This is also consistent when one interviewee related her experience in a small firm 'back there we did not think about measurements, whatever it took, we just got the job done. For us innovation is in day to day activities in everything we do' [INT_B].

R\&D has important implication on the measurements which may be used to assess the inputs to innovation.
Table 15

Coverage of aspects by different metrics

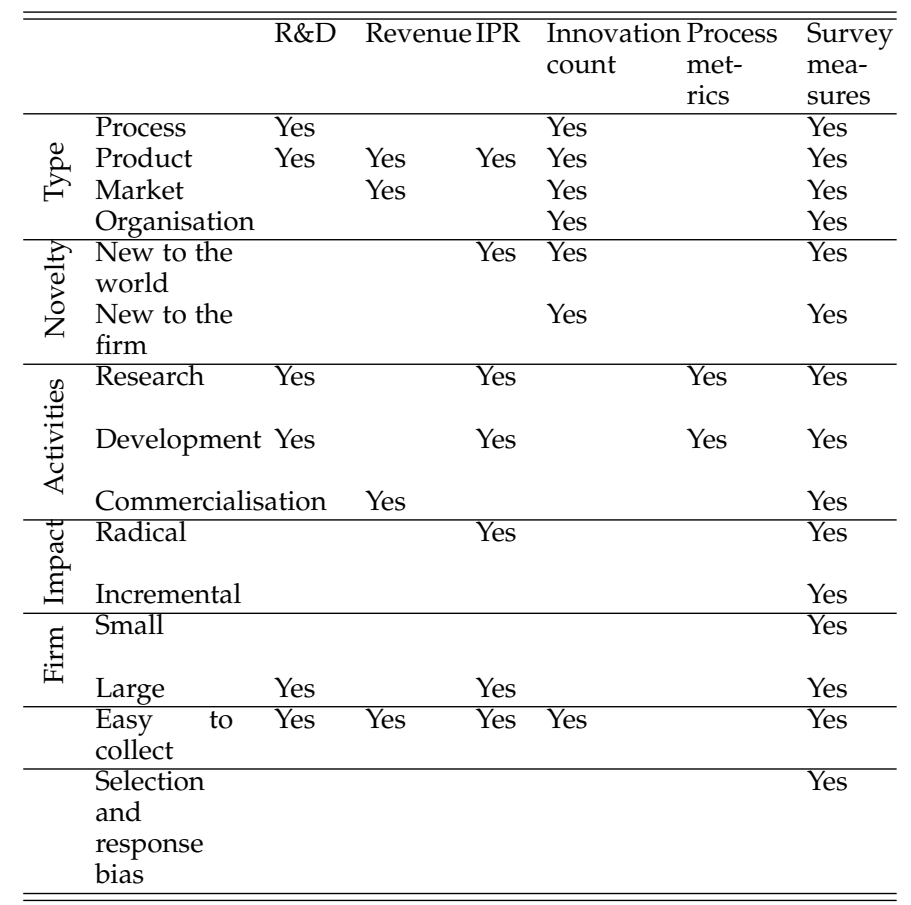

However, this measure has no necessary relation to innovation output [104]. Since most of the software firms are SMEs, which as discussed above do not have dedicated research departments, therefore the percentage of sales spent on R\&D, number of employees dedicated to R\&D etc. may not be useful in their context.

Revenue-based measures: Innovation measurement is often restricted to revenues generated by new offerings to the market [22]. Apparently, this a straight forward measure and organisations often tend to use it. Although it gives a good measure of market success of the innovation but solely relying on this metric can have negative effects on innovation. If innovation are assessed by sales generated, organisation will develop a risk averse culture and it will create a negative effect on creativity. Overtime organisation will start emphasising on incremental innovations and overlook the importance of radical and breakthrough innovations as they have the risk of bringing monetary returns.

One interviewee [INT_D] called it the worst innovation metric as there are confounding factors in success of innovation in the market. She emphasised the importance of measuring that how well the innovation fulfils the intended purpose.

Another interviewee [INT_G] criticised the sales based measure as 'it is so after the fact' that is it gives no transparency in the internal working of the organisation. Other interviewees called sales a tricky measure and that it is difficult to track sales to individual innovations 
[INT_F] [INT_D]. One of the interviewees [INT_G] mentioned that her organisation does not trace which patents are in which products. Another interviewee added that even if patents are tracked, the life-cycle of the products and that of innovations makes it extremely complex to track sales [INT_B]. Moreover, other interviewee [INT_F] questioned on how to define a time period for return on investment as innovation may be embedded in a suite of applications and which in combination with other components delivers value.

IPR-based measures: A large number of selected primary studies use IPR based metrics for measuring innovation output especially patent counts and patent citations based data. However, there are a number of limitations in using patent based measures for innovation measurement especially for innovation in software industry. This prompted a detail investigation into the role of IPR in software and particularly in innovation measurement in software. The issues and challenges with IPR based metrics for software industry are briefly discussed below.

Following are some of the issues with use of patents as an indicator of innovation:

- Patents only tell about the invention phase of innovation [104] and cannot be used to non-patent-able innovations and technology e.g. business formulae [103].

- Innovations may not be new to the world [103].

- Some patents do not have any commercial value [103] [104]. Moreover, the importance and economic value of two patents cannot be covered in citation analysis [103].

- The use of patents is solely to prevent competitors from using it [103].

- Difference of industry's propensity to patent innovations [103] [104].

- Small firms have a lower probability to patent thus under estimation of the innovation activity [103] .

- Firms that collaborate in R\&D tend to apply for more patents to protect their knowledge thus over estimate innovative activity [103].

- The first is that the propensity to patent a new idea may vary across regions. The second is that patents may have dissimilar contents of ideas, with some patents containing many ideas and other relatively few [105].

- Patents are subject to erratic year-to-year fluctuations [106]

The use of patent based measures is further aggravated by the ongoing debate about the patentability of software, process of patent protection and cost associated with it. Software giants [107] [108] [109] and trade ministers [108] are in favour of making software patent-able for following reasons:

- Incentive to invest in $R \& D$ [108] with a possibility of litigation in case of infringement [107].
- Monetary benefits from licensing agreements, patent taxes [107] and royalties [109].

- Ability to control the marketplace [109].

- Patents serve public interest by disclosure of innovations [108].

- Europe to compete against USA as they have significantly developed IPR.

- One interviewee [INT_D] explained that sometimes start-ups use patents for economic reasons, as having patents increases their profile on papers and attracts potential buyers.

Among various IPR like copyrights, trade secrets protection and non-disclosure agreements to protect software, patents are the strongest [110] as patents protect the idea of an invention[107] [110] [111]. Therefore if software patents were issued, a developer who working independently finds a new way with different code to achieve a similar end result (functionality) would be infringing the patent [107] [111] [112]. Small companies [107] and open source community [107] [113] are against patent protection for exactly the opposite reasons:

- They cannot afford to sue big corporations for infringing their patents [107], as one of our interviewee [INT_D] said 'there is no use of a patent if you do not possess the muscle to defend it'.

- They cannot afford to pay patent taxes [107].

- Patents will hinder decentralised development of software like free open source software projects [108].

- By patenting standards and protocol the interoperability of different systems will be affected [108].

- Expenditure on patents and litigation at the cost of innovation [113].

- Cost of patenting is not affordable for small companies [113].

Software development is more evolutionary than revolutionary. However, the patent can be acquired only for inventions which are novel to the world and not obvious at the time invention was made [109]. Aharonian [109] argues that the large number of patents being awarded for software is alarming. The concerns are about the content for which patents are being awarded [107], [109]. Some of these patents are 'overly broad' and intimidating to small companies and individuals [113] e.g. patent awarded for Dynamic Frequently Asked Questions (FAQ) [109]. Some authors like Webber [114] argue that software patents can be equally useful for both small and large companies but broad and invalid patent claims should be abolished. The deteriorating quality of software patents is associated with the following reasons [109]:

- Indifference to prior art. Prior to submitting a patent application the applicant has no obligation of looking for existing work. Most patent applications inadequately the prior art e.g. in the last 20 years $80 \%$ of applications have cited only one reference from published literature [109]. Moreover, patents office 
has lack of access to published literature [109] [114]. You can submit anything in USPTO and get a patent for it, the system is completely broken [INT_G].

- Flood of patent applications. Understaffed, patent office is overwhelmed with the number of applications to process [109] with over 300,000 patent applications to United States Patent and Trademark Office (USPTO) per year [113]. Meanwhile, the employee turnover is high and the examiners are under qualified [109].

- Patent examiners' assembly line working conditions. Time constraint and pressure to accept the applications on examiners [109].

Klemens [115] argues that essentially all software programs implemented in any programming language are mathematical instruction to determine states of a state machine. He claims that to foster basic research and innovation the software patents should be abolished. The implementation of ideas by coding, testing and debugging are activities that take investment and hard work. Thus, copyrights are enough to ensure that any competitor will have to develop the product from scratch giving idea originator ample competitive advantage [107] [111] [113]. As one of our interviewee said 'We innovate and move to developing new things ... to deliver the same functionality as a competitor, involve the same steps as if the idea was generated internally'.

Copyrights prevent competitors from selling duplicated or modified copies of the program and yet offers freedom to allow development of programs that offer similar functionality [108]. This system of protection has provided incentive and enabled fast pace of innovation in software industry [107]. Unlike patents, copyrights allow duplication of functionality therefore they will not hinder interoperability [108] and will assist innovation in the marketplace [113].

Furthermore unlike the patents protection through copyrights is cheap [110] [113], easily acquired and requires minimal originality [112], there are standard copyright licenses, Freeware, General Public License (GPL) and CreativeCommons etc. [113]. Patents cannot cover artistic, creative work thus to protect graphics intensive user interfaces, games and websites copyrights will be the only choice [112].

Lamastra [50] conducts a small study analysing the use of traditional instruments in Italian software firms. It was found that only nine out of the 323 firms analysed, used such means. Five companies used trademarks (35 trademarks for $26 \operatorname{logos}$ and nine company names), three companies held patents (15 patents in total) and three were involved in scientific and technical companies (two of which are among the five companies having a trademark as well).

The issues in patents coverage, ongoing debate, the resistance in adoption of patents and empirical data reported above suggests that patents are not frequently used in software sector formed mainly by SMEs [50]. Therefore patents based direct and derived measures are not very useful in software industry and alternate metrics must be used [50] [103].

Counts-based measures: It is perhaps the most trivial measure and includes number of ideas generated, number of ideas financed, number of new products introduced in the market etc. The issue with this measurement is that it does not say much about the quality of the attribute measured. For example when counting ideas, the important and challenging thing is assessing the quality of the ideas [INT_G] [INT_F]. Similarly, when counting number of features the issue is that not all features are equal or comparable since the size of features, development effort or delivered value are important aspect as well [INT_B].

Process, investment-based and survey measures: When talking about innovation measurement, it is important to measure the output and performance. It is also equally important to assess the environment and capability of organisation for innovation. One interviewee [INT_A] said that measuring the climate for innovation is more important and useful than measuring the innovation output itself since that is where the organisation is picking the ideas. However her organisation currently do not measure those factors. Innovation potential, amount of exposure to customers' needs, how many hours per month spent with our customers designers, service people and end users of the machine [INT_A].

Innovation is not just about bringing something new to the market it is also about winning the 'mind share' and being perceived as innovative [INT_G]. Hence it is important to measure the social capital and image of the company which is not captured by sales of the products alone. Furthermore it is useful to measure the creativity of the employees and then also to analyse if the there are avenues and outlets for creativity in the company.

In interviews and literature review we found that the importance of these factors is well acknowledged but the results of both interviews and questionnaire suggest that it is not currently practised in the industry. The reasons may include that such data is often more subjective, hard to gather, evaluate and analyse. As one interviewee [INT_C] said innovation measurement is about assessment of innovation capability. However, by measuring resources and other necessary factors we cannot guarantee that we will be innovative. Perhaps this is the reason why organisations often fail to undertake this type of measurements.

\section{Proposed model}

Undoubtedly, innovation is hard to measure [116]. A model with various dimensions of innovation is required to provide a meaningful foundation for measurements [117]. Since innovation is not fully understood, there is a lack of exact model [117], which implies that there are no known right measures of innovation [116]. However, in 
the absence of the exact measures organisations should use the available measures to develop insights into its innovation program [116].

We used conceptual analysis method on the findings of systematic review to proposed an innovation measurement model (see Section 4). Using the different perspectives of innovation and the key aspects for innovation measurement identified by the systematic review, we developed an innovation measurement model, as shown in Fig. 27. This model was further refined after academic and industry validation. From the outset the model identifies three main elements of measurement, innovation capability, innovation output and impact of innovation. Unlike the current strict reliance on sales as the sole measure for innovation which may produce negative effects on innovation climate of the organisation. This model highlights the opportunity of a more comprehensive approach towards innovation measurement. Each of these aspects identified in the model can be measured quantitatively (using both objective and subjective metrics). Metrics for each of these aspects identified from literature have been aggregated and categorised in this study.

In the following sections, the aspects of innovation and their importance that lead to creation of this model are discussed.

\subsection{Innovation process model}

In general, innovation process has been depicted as two models: linear model and chain-linked model. In linear model (Fig. 25), there are sequential activities, which usually starts with basic research, followed by applied research and development and ends with production of diffusion [1]. According to Bush [118], basic research plays an important role in innovation. Basic research results in new knowledge, new principles and new conceptions, which in turn are developed into new products or processes. The new knowledge might not give a complete solution to a problem. At this point, applied research is undertaken to provide the complete solution.

Fig. 25. Linear model of innovation (inspired from [1])

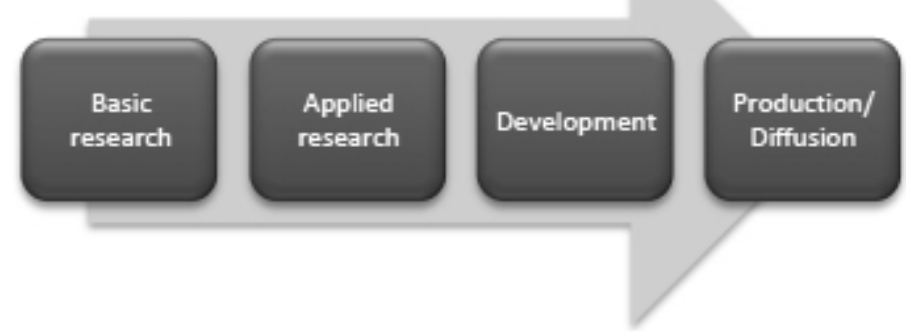

The linear model (Fig 25) was later challenged by Kline [2] who argued that innovation process is not that simple. The model missed the feedback path to and from each process. Therefore, he suggested the chain-linked model (see Fig. 26), which he claimed was consistent with the nature of technological innovation.

Fig. 26. Chain-linked model of innovation (inspired by [2])

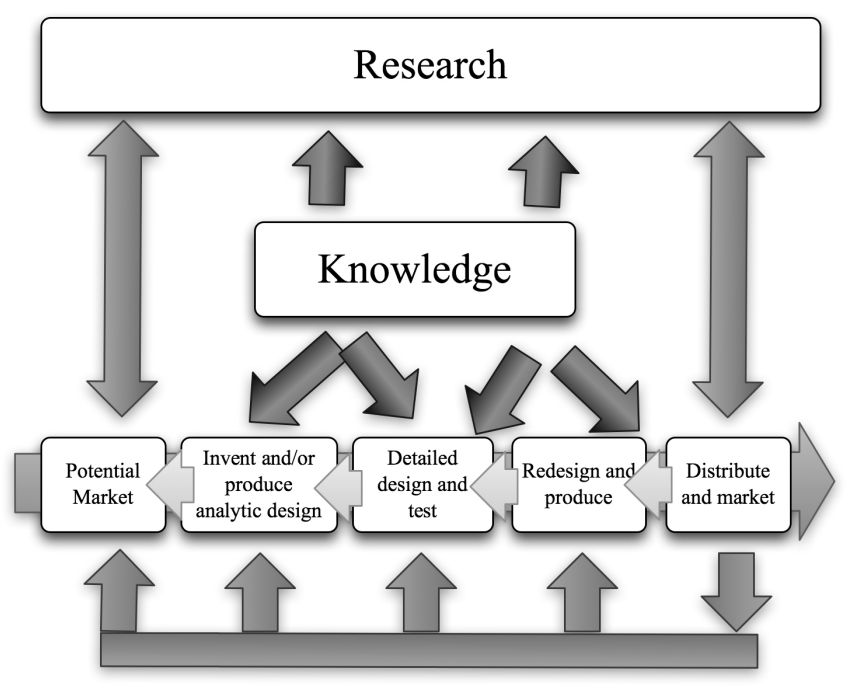

In chain linked model, there are five main paths:

- Central-chain-of-innovation. Knowledge plays an important role and is required in different stages e.g., design, development, production stage.

- Feedback path from perceived market and users' needs to potential for improvement of product or services.

- Research path. When current knowledge fails to support information, research is undertaken.

- New science push. Alongside the development process, new knowledge is used.

- Feedback from product innovation to science.

Innovation is a non linear evolving process [19] [119] that needs to be managed and guided [119]. It is how a firm produces innovation output from innovation inputs [117] [119] [120] under contextual determinants [117]. In this study, we do not propose a new innovation process model; instead we focus on identifying the key elements for innovation measurement. Hence, our model does not depict a flow of innovation stages. Innovation process has been divided into three main phases, having these gates or benchmarking points helps in measurements and does not in anyway suggest or dictate that the process is as simplistic to have three sequential steps.

- Research phase [25] including concept generation, evaluation and feasibility [16] [24]. The goal of this phase is identification of new opportunities [19].

- Development phase [24] [25] including project planning, design, coding and testing [16] product development taking the innovation concept, through development and transfer to manufacturing and use [19].

- Use in production [25] or commercialisation [16]. 
Fig. 27. Model for innovation measurement

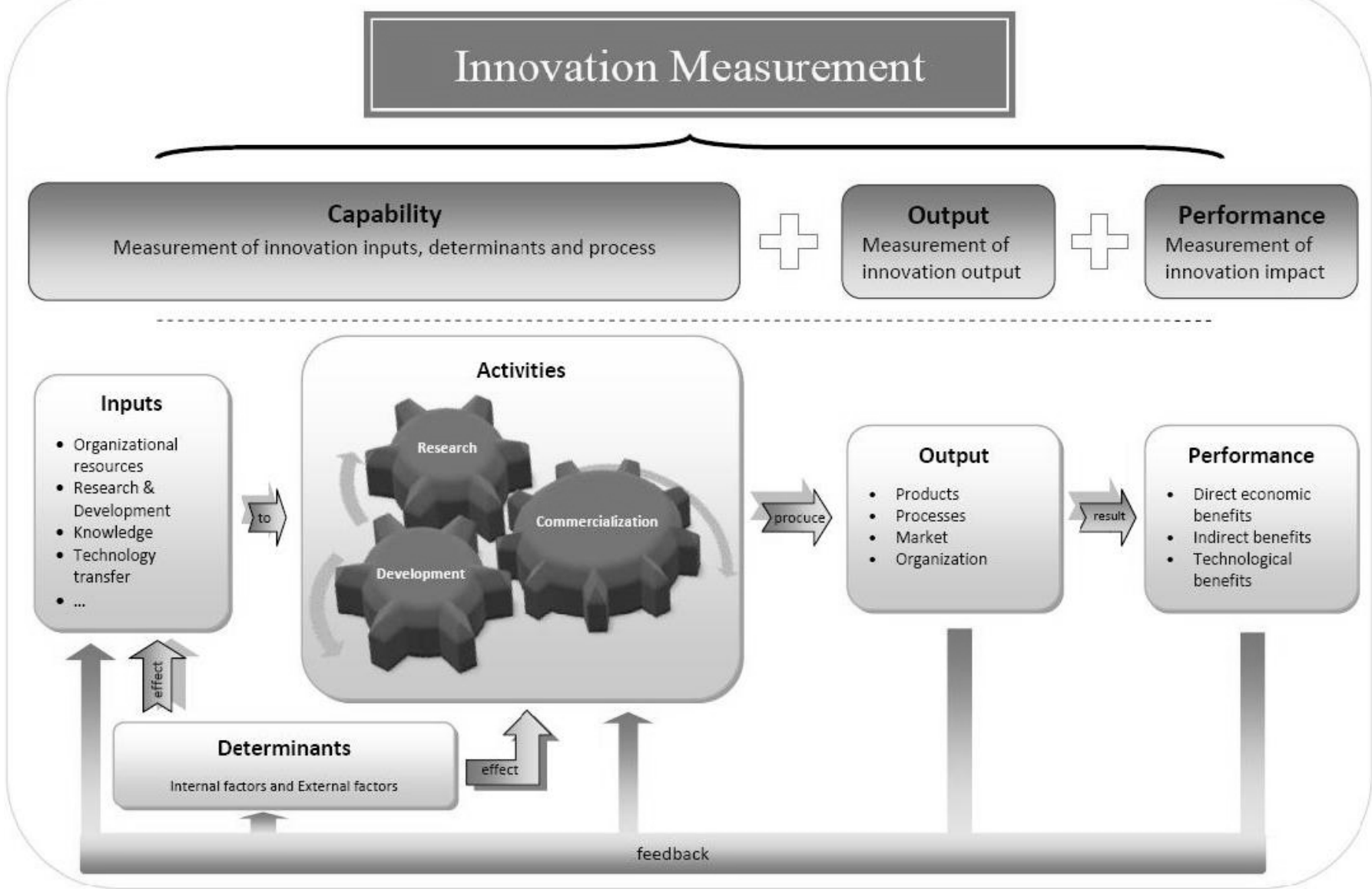

\subsection{Key aspects of innovation}

From systematic review, we found that there are three dimensions of innovation that can be measured: capability (some papers exchange the term capability and capacity to address the potential ability of the organisation to innovate), output and success. The determinants and metrics reported in the literature were classified according to this dimension. The classification was done based on the description of the determinants and metrics given in the selected primary studies.

The innovation capability is the willingness and ability to create, adopt and imitate new ideas to implement and commercialise them in order to satisfy current and future needs [3] [121]. It means mobilising organisational knowledge and other competencies necessary for improving existing and developing new processes and products and the capacity to respond to accidental technology shifts and unexpected opportunities created by the competitors [3]. Innovation capability includes assessment of innovation inputs, availability and quality of positive influencing factors and innovation process assessment.

Innovation is conceptualised as a change in the input and output of innovation function [25] [122]. When viewed as a process like any other business process, innovation cannot be solely characterised and captured by the input and output metrics [70]. Organisations need a range of measures to evaluate key aspects of innovation process [24]. The key aspects of innovation processes that have been identified as important for measurement are the following:

- Inputs are resources like capital, labour, knowledge and time [14] [24] [123]

- Innovation process performance means tracking the people and processes acting upon the inputs [24].

- Intermediate output [123] as a proxy for economic output using patents acquired. Patents are good indicators of new technology creation however they do not measure the economic value of these technologies [123].

- Output is the measure of commercialised ideas [123] resulting from innovation inputs [124].

- Cash pay back [24] or innovation performance refers to economic returns of innovation [125].

- Indirect benefits are not easily quantifiable often involve survey measures, third party rankings and benchmarking to evaluate organisation impact, brand image [24] competitiveness in market [94].

There is a general consensus that for changes to be considered as innovation, it must be commercialised (introduced into market or implemented in the organisation). This confirms with the business goals of the 
commercial organisations. This draws the line between anything that is new and something company considers has value. However, development of such products, processes and methodologies does provide the organisation a learning opportunity and adds to the capability of the organisation. This aspect is covered through the feedback loop in the model.

\subsection{Purpose of the model}

This model has benefits for both academia and industry. However it is important to identify its purpose and utility. The model has the following contributions:

- This model is not prescribing any innovation process. However, this model identifies the aspects of innovation that are measurable and thus serves as a starting point for innovation measurement.

- The model serves as a generic map that covers the entire range of activities and aspects putting them all in perspective.

- It serves as the basis for future research e.g. to study the effect of various determinants on innovation.

- Contrary to the current practice, this model emphasises the need of comprehensive measurements covering range of activities (Unlike the sole focus by some on sales based metrics).

- This model can help different stakeholders to communicate when talking about innovation. It will provide a common perspective to everyone involved in innovation measurement.

To understand the use of this model and to put it in the perspective of overall innovation measurement program, let us use an example of an innovation measurement program implementation using Goal Question Metric (GQM) [102]. We take GQM as an example as it provides a well structured and directed approach for measurement. A measurement program using GQM has four steps [126]:

- Planning phase: In this phase, basic requirements like training and management commitment for measurement program are acquired. Plans of measurement for selected project are defined and integrated in the project plan.

- Definition phase: In this phase the measurement program is specified and documented by defining goals, creating questions and identifying metrics for measurements.

- Data collection phase: Actual data collection for the metrics identified in definition phase is done and documented.

- Interpretation phase: In this phase the data is analysed to answer the questions and evaluate whether the stated goals have been attained.

These phases can be identified in other measurement frameworks as well e.g. Practical Software Measurement (PSM) has establish commitment, plan, perform and evaluate measurement as four phases [127]. The definition phase, using GQM contains three steps as shown in Fig. 28. The proposed model in this study is useful during this phase. The suggested use of proposed model is briefly discussed below in each of the steps involved:

- Step A (Conceptual level [102]): Based on the analysis of organisation policy statements, strategic plans and interviews of relevant stakeholders the purpose of the goals is derived [102]. The goals are defined for objects relative to the quality models, measurement perspectives and particular environment. These objects include processes, products and resources [102]. The proposed model will be useful for identifying the objects of goals through its conceptual categorisation of capability (Inputs, processes and determinants), output (product, process, organisation and market) and performance (direct economic, indirect and technological benefits).

- Step B (Operational level [102]): Derive questions that try to characterise the objects of measurement identified in Step A (using the proposed innovation measurement model) with respect to a selected quality issue and to determine its quality from the selected [102].

- Step C (Quantitative level): The model through categorisation of metrics found in the literature assists in choosing appropriate metrics for answering the questions in Step B. The objective and subjective metrics available help quantitatively answer these questions, which in turn help attain the goals of measurement.

Fig. 28. Measurement program using GQM

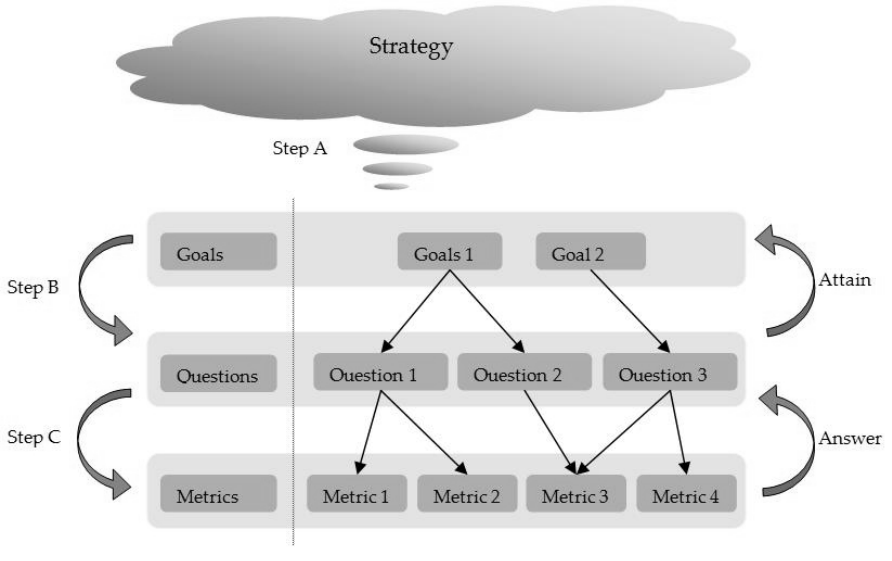

\subsection{Validation results}

All of the interviewees' expressed a positive feedback for the model about the coverage of key aspects related to innovation measurement as shown in Fig. 27. However, there were some critical issues and concerns raised which are discussed below.

One interviewee [INT_D] expressed concerns about how "value" is aligned with the innovation measurement programs undertaken by a company. She also mentioned the problems with over reliance on sales 
based measures. Since, this was alarming as one of the purposes of this model was to emphasise the importance of non-sales and output based measures. Therefore, we redrew the model focusing on the capability, output and performance. We emphasised more on the capability aspect of innovation measurement and made it explicit that performance measurement does not solely comprise of sales measurement. It was shown in the model that performance measurement itself has three aspects of which direct economic benefits (based on sales data) is one dimension.

One of interviewee from academia [INT_E] found the term "front end of innovation" misleading as it gives impression of linear innovation process. Therefore, we substituted with a more commonly used term "research" as suggested by Jensen et al. [25]. Furthermore, the model was modified to give a more neutral perspective of the process of innovation and just emphasise the three interacting and mutually constituting activities of research, development and commercialisation.

One interviewee [INT_A] found separate feedback and learning loops from output and performance confusing. She suggested to have only one feedback loop. Therefore, to make it more understandable the model was modified to have feedback from output and performance to inputs, determinants and activities.

Two industry interviewees expressed a need for customisation of this generic model to their company specific practices and process models for further validation and use [INT_A] [INT_B]. The purpose of this model is to give a high-level overview of the key aspects of innovation measurement and it can be used with existing measurement frameworks to measure innovation. This validation however was beyond the scope of this study and can be done in a case-study in future.

One interviewee [INT_F] raised an issue that some organisations in their industry are not into product development and just build IPRs and look for potential buyers. Therefore, she argued that the commercialisation step may not be applicable for such businesses. We think that this business approach can also be accommodated in the proposed model where the commercialisation would mean putting the patents in the market (meaning to find a potential buyer for the IPR or to hunt for any infringements).

\section{VALIDITY Threats}

Major threats to validity related to research methods implemented for this study including systematic literature review, interviews and survey have been identified and are discussed below.

\subsection{Identification of primary studies}

The keyword 'innovation' is a very generic term and has been discussed almost in all domains [43], including software engineering. We found that studies of innovation in software domain were not only published in software engineering journals but also in many relevant fields e.g. management, organisation studies, finance, etc. To minimise the probability of missing relevant studies, we took the following steps:

1) To cover literature from other important fields like management, economics and finance etc., we did not restrict the literature review to software related databases. Although we did not include any studies from fields related to manufacturing, chemical, medical and education still this decision led to a large number of studies i.e. 13,401 studies with 2,621 duplicates identified by the reference management tool. The duplicates were due to the overlapping coverage of journals by different reference databases.

2) To consider quality articles in this study, only journal publications were included in the study. This decision was also motivated by the observation that the best papers presented in a conference were subsequently published in a journal as well.

3) For better coverage, we performed manual search for grey literature [37].

4) We collaborated with a PhD student in BTH School of management who is working in the same area. This collaboration included discussion and exchange of important materials used in each other's work.

\subsection{Primary studies selection and data extraction}

Since this study involves many fields, we required an effective and efficient strategy to minimise researchers bias in studies selection [37]. Therefore, we defined three levels of inclusion/exclusion criteria, which were applied on the results of the search strings. We also used a defined data extraction strategy.

The criteria were formulated explicitly as clear as possible to avoid misunderstanding between the reviewers. Based on these criteria, each reviewer selected the relevant studies individually. If one of the reviewers could not decide whether to accept or reject, the decision was made based on agreement among them. To minimise the threat of misunderstanding, as suggested by Brereton et al. [128], we piloted the selection criteria to reach the agreement among the reviewer on the criteria. This piloting was aimed to see whether the reviewers already have the same understanding about the criteria and to check whether the criteria were too strict or too loose.

\subsection{Questionnaire}

Aside from the threats of systematic literature review, several threats to validity of questionnaire were identified. The instrumentation threat which is caused by bad design leads to misunderstanding of the topic under discussion [41]. It was minimised by piloting the questionnaire with eight students of Masters of Software Engineering (SE) and two researchers from industry with 
masters in SE. The aim of this pilot was to see whether the questions were clear and understandable and to measure the time taken to fill out the questionnaire. We also sent out the questionnaire to our supervisor for approval to ensure the completeness and validity of design. We noticed that some of respondents were reluctant to fill in the questionnaire or left it incomplete. Hence, the layout was refined and made simple. Furthermore, depending on the answers of respondents they were only shown relevant questions on subsequent pages.

Another threat to validity was the threat of not having a representative sample of target population (which for this survey were the professionals in software industry with different roles) [41]. To minimise this threat we contacted respondents with different roles from software engineers to executives, working in micro to large organizations around the globe. To enable us to reach such diverse and geographically distributed target population, we developed a web-based questionnaire and gave one week for respondents to fill in. The invitations were sent to our contacts through personalised individual emails and posting on researchers' alumni mailing lists.

The maturation threat caused by the participants change in behaviour with the progression of time can distort the results [41]. This happens if subjects acquire new knowledge during the process or become detached. However, with a short questionnaire which was open only for a week we think we were able to minimise this threat. As the respondents may develop their understanding while filling in the questionnaire, different type of questions e.g. multiple choices, Likert scale (1 to 5) and open ended questions were used.

Interruption and disturbance during the participation may influence the results of the study [129]. However, as this was an online questionnaire this threat was beyond the control of the reviewers.

Exposing the hypothesis may affect the way the survey respondents answer the questions [129]. Therefore to minimise this threat only general information about the intent of the study was given. Also the questions were phrased in a neutral manner e.g. the questions about perception of innovation, were indirect statements rather than using the keywords to hide the findings of the systematic review which we were being confirmed.

Drop out from the study (once they have started to participate) may affect the representative sample and thus the results [129]. This study has this threat as $28.28 \%$ of respondents in the survey did not complete it. However, we think that we still got enough representation in each target category for results to be still valid.

\subsection{Interview}

Although interview is useful to collect historical information, it also has threats to validity. The presence of interviewers may bias the responses [33]. The bias might be also caused by the unequal articulated and perceptive by all interviewees [33]. Therefore, for each organisation, we interviewed two people with different roles. Most of the interviewees were at managerial level (see Appendix L). Each interview lasted between 45-60 minutes in their offices. A short interview also minimised the interviewee maturation threat [41], boredom effect [129] and kept them focused on the task.

To validate the framework and gain valuable feedback we conducted face-to-face meeting. This enabled a better and more effective presentation of ideas and arguments. However, due to the constraints of time and limited contacts we were constrained the interviews in Sweden only. Thus, to reduce the threat to generalisation of results [41], we tried to get a mix of representatives from different domains within the software industry of Sweden (ranging from software solutions and embedded software in manufacturing, software intensive product development in telecommunication and representatives from firms with pure software product development). Furthermore, the academics interviewed in this study also come from both School of Computing and Management at BTH.

Experts with relevant experience and understanding of the topic of the study were interviewed for effective validation. This also proved useful to validate the completeness of the model. However we think that the study might be affected by the high motivation of the interviewees as they were all interested in the topic themselves and somehow involved in similar work. Although various critical points and discussions were raised during interviews but the motivation an interest of interviewees in the area may have resulted in biased results [41].

To minimise the threat of evaluation apprehension [41] where respondents may overstate the positive aspects [129], in both interviews and surveys participants were guaranteed anonymity and that the results will be only used by the researchers for this study. Moreover, the decision to use three research methods with overlapping intent was to supplement the techniques and improve the ability to generalise the findings of this study. For example to understand the perception of innovation, we looked for definitions in the literature, indirect questions in survey and open ended questions in interviews.

Disturbance and interruptions can effect the results [129]. To minimise this threat, interviewees were requested for appointments well in advance and they choose the time of interview on their convenience and availability. The interviews were conducted with closed doors and there were no interruptions or disturbances during the interviews.

During the course of the experiment the subjects should not be allowed to communicate with each other as it may affect the results [129]. In this study, this was beyond the control of the respondents as the questionnaire was online and was open for seven days. For the interviews with the industry practitioners the interviews in each company were conducted in the same day which helped us minimise this threat. 


\section{CONCLUSIONS \& FUTURE WORK}

Until today, academia and industry describe innovation in different ways. They focus on different aspects of innovation based on a particular perspectives. This difference in views affects how innovation measurement initiatives are conceived (key aspects of innovation) and executed (metrics needed to capture innovation).

Systematic review helped us to identify the quality of metrics. It was found that there was little information about the proposed metrics including how to calculate, collect and interpret them. This limits the uses of the metrics in practice. Although a number of metrics have been proposed in literature, only a few of them have been validated in industry trial. Most of the metrics are validated through statistical analysis. This lack of reliable metrics could be the main reason why industry claim that they do not have enough metrics. Hence, industrial trials are imperative to establish the reliability and usability of the metrics. Moreover, there was no collection of metrics for innovation measurement that can be used by industry.

This study found that innovation measurement is considered important in both academia and industry. However, it was found that there is a lack of defined innovation process and measurement programs in industry. Similarly, we found that none of the well-known measurement frameworks have been used to measure innovation. This may be caused by lack of comprehensive models of measurement. The existing models of innovation measurement do not cover the whole aspects of innovation. Furthermore, they do not relate which innovation metrics can be used to measure the key aspects of innovation.

In this study, our contribution is to identify the key measurable aspects of innovation and map them into a model for measurement. The model incorporates the determinants for innovation process and the metrics for measuring innovation capability, output and success. The proposed model is developed as a high level model, which covers the most common aspects of innovation used in industry and academia. The model is generic and so it can be implemented with the existing measurement frameworks e.g. GQM, PSM, etc. However, additional work on validation needs to be undertaken.

\section{References}

[1] B. Godin, "The linear model of innovation: The historical construction of an analytical framework," Science, Technology and Human Values, vol. 31, no. 6, pp. 639-667, 2006.

[2] S. J. Kline, "Research, invention, innovation and production: Models and reality," Department of Mechanical Engineering, Stanford University, Tech. Rep., 1989.

[3] G. Akman and C. Yilmaz, "Innovative capability, innovation strategy and market orientation: An empirical analysis in turkish software industry," International Journal of Innovation Management, vol. 12, no. 1, pp. 69-111, 2008.

[4] OECD, Oslo Manual - Guidelines for Collecting and Interpreting Innovation Data, 3rd ed. OECD Publishing, 2005.

[5] G. H. Gaynor, "Innovator: What does it take to be one?" IEEE Antennas and Propagation Magazine, vol. 43, no. 3, pp. 126-130, 2001.
[6] M. Kivimäki, H. Länsisalmi, M. Elovainio, A. Heikkilä, K. Lindström, R. Harisalo, K. Sipilä, and L. Puolimatka, "Communication as a determinant of organizational innovation," $R$ and $D$ Management, vol. 30, no. 1, pp. 33-42, 2000.

[7] G. Johnson, K. Scholes, and R. Whittington, Exploring corporate strategy, 7th ed. Prentice Hall, 2004.

[8] M. G. P. L. Narayana, "A framework approach to measure innovation maturity," ser. Proceedings - Engineering Management Conference, vol. 2, 2005, pp. 765-769.

[9] P. A. James, H. Knut, C. M. David, L. S. Harold, and T. Andrew, "A bcg senior management survey - innovation 2008: Is the tide turning?" Boston Consulting Group, Tech. Rep., August 2008.

[10] S. Brown and K. Eisenhardt, "Product development: Past research, present findings, and future directions," The Academy of Management Review, vol. 20, no. 2, pp. 343-378, 1995.

[11] H. B. Rejeb, L. Morel-Guimares, V. Boly, and N. G. Assilou, "Measuring innovation best practices: Improvement of an innovation index integrating threshold and synergy effects," Technovation, vol. 28 , no. 12 , pp. 838-854, 2008.

[12] M. Assink, "Inhibitors of disruptive innovation capability: A conceptual model," European Journal of Innovation Management, vol. 9, no. 2, pp. 215-233, 2006.

[13] H. Romijn and M. Albaladejo, "Determinants of innovation capability in small electronics and software firms in southeast england," Journal of Research Policy, vol. 31, no. 7, pp. 1053-1067, 2002.

[14] A. Muller, L. Vlikangas, and P. Merlyn, "Metrics for innovation: Guidelines for developing a customized suite of innovation metrics," IEEE Engineering Management Review, vol. 33, no. 4, pp. 66-72, 2005.

[15] L. Gumusluǒlu and A. Ilsev, "Transformational leadership and organizational innovation: The roles of internal and external support for innovation," Journal of Product Innovation Management, vol. 26, no. 3, pp. 264-277, 2009.

[16] S. Nambisan, "Software firm evolution and innovationorientation," Journal of Engineering and Technology Management, vol. 19, no. 2, pp. 141-165, 2002.

[17] J. Hauser, G. J. Tellis, and A. Griffin, "Research on innovation: A review and agenda for marketing science," Marketing Science, vol. 25, no. 6, pp. 687-717, 2006

[18] L. Mathiassen and P. Pourkomeylian, "Managing knowledge in a software organization," Journal of Knowledge Management, vol. 7, no. 2, pp. 63-80, 2003.

[19] T. D. Kuczmarskl, "Five fatal flaws of innovation metrics," Marketing Management, vol. 10, no. 1, p. 34, 2001.

[20] J. Brown and P. Duguid, "Organizational learning and communities-of-practice: Toward a unified view of working, learning, and innovation," Organization Science, vol. 2, no. 1, pp. 40-57, 1991.

[21] D. Hislop, Knowledge management in organizations. Oxford University Press, 2005.

[22] P. A. James, H. Knut, C. M. David, L. S. Harold, and T. Andrew, "A bcg senior management survey - measuring innovation 2008: Squandered opportunities," Boston Consulting Group, Tech. Rep., August 2008.

[23] J. Alegre, R. Lapiedra, and R. Chiva, "A measurement scale for product innovation performance," European Journal of Innovation Management, vol. 9, no. 4, pp. 333-346, 2006.

[24] J. P. Andrew and H. L. Sirkin, "Aligning for innovation," Global Business and Organizational Excellence, vol. 27, no. 6, pp. 21-39, 2008.

[25] P. H. Jensen and E. Webster, "Another look at the relationship between innovation proxies," Australian Economic Papers, vol. 48 , no. 3, pp. 252-269, 2009.

[26] A. R. Shapiro, "Measuring innovation: Beyond revenue from new products," Research Technology Management, vol. 49, no. 6, pp. 42-51, 2006.

[27] C. Ebert and R. Dumke, Software measurement: establish, extract, evaluate, execute. Springer-Verlag Berlin Heidelberg, 2007.

[28] N. Becheikh, R. Landry, and N. Amara, "Lessons from innovation empirical studies in the manufacturing sector: A systematic review of the literature from 1993-2003," Technovation, vol. 26, no. 5-6, pp. 644-664, 2006.

[29] M. M. Crossan and M. Apaydin, "A multi-dimensional framework of organizational innovation: A systematic review of the literature," Journal of Management Studies, Dec. 2009, to be published. 
[30] P. Berg, J. Pihlajamaa, J. Poskela, T. Lempiala, U. Haner, and A. Mabogunje, "Measurement of the innovation front end: viewpoint of process, social environment and physical environment," ser. PICMET '08 - 2008 Portland International Conference on Management of Engineering Technology. Piscataway, NJ, USA: IEEE, 2008, pp. 1112-20.

[31] T. Gorschek, S. Fricker, K. Palm, and S. Kunsman, "A lightweight innovation process for software-intensive product development," IEEE Softw., vol. 27, no. 1, pp. 37-45, 2010.

[32] S. C. Misra, V. Kumar, and U. Kumar, "Goal-driven measurement framework for software innovation processes," ser. Proceedings of the 2005 International Conference on Software Engineering Research and Practice, SERP'05, vol. 2. Las Vegas, NV, United states: CSREA Press, 2005, pp. 710-716.

[33] J. W. Creswell, Research Design: Qualitative, Quantitative, and Mixed Methods Approaches, 3rd ed. Sage Publication, Inc, 2009.

[34] L. M. Given, The SAGE Encyclopedia of Qualitative Research Methods. Sage Publication, Inc, 2008, vol. 1\&2.

[35] C. Busch, P. S. D. Maret, T. Flynn, R. Kellum, S. Le, B. Meyers, M. Saunders, R. White, and M. Palmquist, "Content analysis. writing@csu," 2005.

[36] T. Gorschek, P. Garre, S. Larsson, and C. Wohlin, "A model for technology transfer in practice," IEEE Softw., vol. 23, no. 6, pp. $88-95,2006$

[37] B. A. Kitchenham and S. Charters, "Guidelines for performing systematic literature reviews in software engineering, version 2.3," Keele University, EBSE Technical Report. EBSE-2007-01, Jul 2007.

[38] J. C. de Almeida Biolchini, P. G. Mian, A. C. C. Natali, T. U. Conte, and G. H. Travassos, "Scientific research ontology to support systematic review in software engineering," Advanced Engineering Informatics, vol. 21, no. 2, pp. 133-155, Apr. 2007.

[39] C. B. Seaman, "Qualitative methods in empirical studies of software engineering," IEEE Transactions on Software Engineering, vol. 25 , no. 4 , pp. $557-72,1999$.

[40] S. E. Hove and B. Anda, "Experiences from conducting semistructured interviews in empirical software engineering research," ser. Proceedings - International Software Metrics Symposium, vol. 2005. Como, Italy: IEEE Computer Society, 2005, pp. 203-212.

[41] C. Wohlin, P. Runeson, M. Host, M. C. Ohlsson, B. Regnel, and A. Wesslen, Experimentation in Software Engineering: An Introduction. Massachusetts, USA: Kluwer Acedemic Publisher, 2000.

[42] M. Kasunic, Designing an Effective Survey. Carnegie Mellon Software Engineering Institute, 2005, vol. CMU SEI-2005-HB-004.

[43] A. Subramanian, "Innovativeness: Redefining the concept," Journal of Engineering and Technology Management, vol. 13, no. 3-4, pp. 223-243, 1996.

[44] Y. Caloghirou, I. Kastelli, and A. Tsakanikas, "Internal capabilities and external knowledge sources: complements or substitutes for innovative performance?" Technovation, vol. 24, no. 1, pp. 2939, 2004.

[45] J. P. J. de Jong and R. Kemp, "Determinants of co-workers' innovative behaviour: An investigation into knowledge intensive services," International Journal of Innovation Management, vol. 7, no. 2 , p. 189,2003

[46] A. Frenkel, D. Shefer, and S. Roper, "Public policy, locational choice and the innovation capability of high-tech firms: A comparison between israel and ireland," Papers in Regional Science, vol. 82, no. 2, p. 203, 2003.

[47] K. Cormican and D. O'Sullivan, "Auditing best practice for effective product innovation management," Technovation, vol. 24, no. 10, pp. 819-829, 2004.

[48] E. Commission, "The new sme definition - user guide and model declaration," European Commission, Tech. Rep., 2003.

[49] D. E. Krause, "Influence-based leadership as a determinant of the inclination to innovate and of innovation-related behaviors: An empirical investigation," The Leadership Quarterly, vol. 15, no. 1, pp. 79-102, 2004.

[50] C. R. Lamastra, "Software innovativeness. a comparison between proprietary and free/open source solutions offered by italian smes," $R$ and D Management, vol. 39, no. 2, pp. 153-169, 2009.

[51] M. Dodgson and S. Hinze, "Indicators used to measure the innovation process: Defects and possible remedies," Research Evaluation, vol. 9, no. 2, pp. 101-114, 2000.
[52] C. J. Cheng and E. C. C. Shiu, "Re-innovation: The construct, measurement, and validation," Technovation, vol. 28, no. 10, pp. 658-666, 2008.

[53] C. McMillan, "Five competitive forces of effective leadership and innovation," Journal of Business Strategy, vol. 31, no. 1, pp. 11-22, 2010.

[54] F. Damanpor, "Bureaucracy and innovation revisited: Effects of contingency factors, industrial sectors, and innovation characteristics," The Journal of High Technology Management Research, vol. 7 , no. 2, pp. 149-173, 1996.

[55] J. T. Hage, "Organizational innovation and organizational change," Annual Review of Sociology, vol. 25, no. 1, p. 597, 1999.

[56] C. Dibrell, P. S. Davis, and J. Craig, "Fueling innovation through information technology in smes," Journal of Small Business Management, vol. 46, no. 2, pp. 203-218, 2008.

[57] Z. J. Acs and D. B. Audretsch, "Innovation in large and small firms: An empirical analysis," American Economic Review, vol. 78, no. 4 , p. $678,1988$.

[58] A. Singh and V. Singh, "Innovation in services: Design and management," African Journal of Business Management, vol. 3, no. 12, pp. 871-878, 2009.

[59] M. Berger and J. Revilla Diez, “Technological capabilities and innovation in southeast asia: Results from innovation surveys in singapore, penang and bangkok," Science, Technology and Society, vol. 11, no. 1, pp. 109-148, 2006

[60] S. Beugelsdijk, "Strategic human resource practices and product innovation," Organization Studies, vol. 29, no. 6, pp. 821-847, 2008.

[61] M. Parashar and S. Sunil Kumar, "Innovation capability," IIMB Management Review, vol. 17, no. 4, pp. 115-123, 2005.

[62] L. Hannola, S. Kortelainen, H. Krkkinen, and M. Tuominen, "Utilizing front-end-of-innovation concepts in software development," Industrial Management and Data Systems, vol. 109, no. 7, pp. 898-915, 2009.

[63] J. Freeman and J. S. Engel, "Models of innovation: Startups and mature corporations," California Management Review, vol. 50, no. 1, pp. 94-119, 2007.

[64] L. Aiman-Smith, N. Goodrich, D. Roberts, and J. Scinta, "Assessing your organization's potential for value innovation," Research Technology Management, vol. 48, no. 2, pp. 37-42, 2005.

[65] M. A. Dalton, "What's constraining your innovation?" Research Technology Management, vol. 52, no. 5, pp. 52-64, 2009.

[66] A. Kaasa and M. Vadi, "How does culture contribute to innovation? evidence from european countries," Kuidas kultuur soodustab innovatsiooni: Euroopa riikide kogemus., no. 63, pp. 3-39, 2008.

[67] R. Garcia and R. Calantone, "A critical look at technological innovation typology and innovativeness terminology: a literature review," Journal of Product Innovation Management, vol. 19, no. 2, pp. 110-132, 2002.

[68] C. Palmberg, "The sources of innovations - looking beyond technological opportunities *," Economics of Innovation $\mathcal{E}$ New Technology, vol. 13, no. 2, pp. 1-1, 2004.

[69] U. E. Haner, "Innovation quality - a conceptual framework," International Journal of Production Economics, vol. 80, no. 1, pp. 31-37, 2002

[70] P. Banerjee, "Indicators of 'innovation as a process'," Scientometrics, vol. 43, no. 3, pp. 331-357, 1998.

[71] M. J. Orlando and M. Verba, "Do only big cities innovate? technological maturity and the location of innovation," Economic Review (01612387), vol. 90, no. 2, pp. 31-57, 2005.

[72] A. Oke, N. Munshi, and F. O. Walumbwa, "The influence of leadership on innovation processes and activities," Organizational Dynamics, vol. 38, no. 1, pp. 64-72, 2009.

[73] R. Adams, J. Bessant, and R. Phelps, "Innovation management measurement: A review," International Journal of Management Reviews, vol. 8, no. 1, pp. 21-47, 2006.

[74] R. K. Chandy and G. J. Tellis, "Organizing for radical product innovation: The overlooked role of willingness to cannibalize," Journal of Marketing Research, vol. 35, no. 4, pp. 474-487, 1998.

[75] A. Herrmann, T. Tomczak, and R. Befurt, "Determinants of radical product innovations," European Journal of Innovation Management, vol. 9, no. 1, pp. 20-43, 2006.

[76] P. J. De Jong and P. A. M. Vermeulen, "Determinants of product innovation in small firms: A comparison across industries," International Small Business Journal, vol. 24, no. 6, pp. 587-609, 2006. 
[77] C. A. Di Benedetto, W. S. DeSarbo, and M. Song, "Strategic capabilities and radical innovation: An empirical study in three countries," IEEE Transactions on Engineering Management, vol. 55, no. 3, pp. 420-433, 2008.

[78] A. Drejer, "Are you innovative enough?" International Journal of Innovation and Learning, vol. 5, no. 1, pp. 1-17, 2008.

[79] R. Wakasugi and F. Koyata, "Rd, firm size and innovation outputs: are japanese firms efficient in product development?" Journal of Product Innovation Management, vol. 14, no. Copyright 1997, IEE, pp. 383-92, 1997.

[80] A. Carmona-Lavado, G. Cuevas-Rodrguez, and C. CabelloMedina, "Social and organizational capital: Building the context for innovation," Industrial Marketing Management, vol. In Press, Corrected Proof.

[81] F. Damanpour, "Organizational size and innovation," Organization Studies (Walter de Gruyter GmbH \& Co. KG.), vol. 13, no. 3, pp. 375-402, 1992.

[82] A. L. Fruhling and S. Keng, "Assessing organizational innovation capability and its effect on e-commerce initiatives," Journal of Computer Information Systems, vol. 48, no. 1, pp. 133-145, 2007.

[83] J. Linton, "What is innovation, anyway?" Circuits Assembly, vol. 18, no. 4, pp. 18-20, 2007.

[84] H. J. Cho and V. Pucik, "Relationship between innovativeness, quality, growth, profitability, and market value," Strategic Management Journal, vol. 26, no. 6, pp. 555-575, 2005.

[85] E. D. Adamides and N. Karacapilidis, "Information technology support for the knowledge and social processes of innovation management," Technovation, vol. 26, no. 1, pp. 50-59, 2006.

[86] S. W. Geiger and L. Cashen, "A multidimensional examination of slack and its impact on innovation," Journal of Managerial Issues, vol. 14, no. 1, p. $68,2002$.

[87] N. Amara, R. Landry, and D. Doloreux, "Patterns of innovation in knowledge-intensive business services," Service Industries Journal, vol. 29, no. 4, pp. 407-430, 2009.

[88] A. Paladino, "Investigating the drivers of innovation and new product sucess: A comparison of strategic orientations," Journal of Product Innovation Management, vol. 24, no. 6, pp. 534-553, 2007.

[89] C. A. Voss, "Determinants of success in the development of applications software," Journal of Product Innovation Management, vol. 2, no. 2, pp. 122-129, 1985.

[90] F. P. Brooks, "No silver bullet: Essence and accidents of software engineering," Computer, vol. 20, no. 4, pp. 10-19, April 1987.

[91] M. H. Fagan, "The influence of creative style and climate on software development team creativity: An exporatory study," Journal of Computer Information Systems, vol. 44, no. 3, pp. 7380, 2004.

[92] V. Kumar, A. N. S. Persaud, and U. Kumar, "To terminate or not an ongoing r\&amp;d project: a managerial dilemma," Engineering Management, IEEE Transactions on, vol. 43, no. 3, pp. 273-284, 1996.

[93] G. Capaldo, 1. Iandoli, M. Raffa, and G. Zollo, "The evaluation of innovation capabilities in small software firms: A methodological approach," Small Business Economics, vol. 21, no. 4, pp. 343-354, 2003.

[94] V. Chiesa, P. Coughlan, and C. A. Voss, "Development of a technical innovation audit," IEEE Engineering Management Review, vol. 26, no. 2, pp. 64-91, 1998.

[95] J. L. Furman, M. E. Porter, and S. Stern, "The determinants of national innovative capacity," Research Policy, vol. 31, no. 6, pp. 899-933, 2002.

[96] C.-h. Wang, I.-y. Lu, and C.-b. Chen, "Evaluating firm technological innovation capability under uncertainty," Technovation, vol. 28 , no. 6, pp. 349-363, 2008.

[97] R. C. M. Yam, J. C. Guan, K. F. Pun, and E. P. Y. Tang, “An audit of technological innovation capabilities in chinese firms: some empirical findings in beijing, china," Research Policy, vol. 33, no. 8, pp. 1123-1140, 2004.

[98] A. Nirjar, "Innovations and evolution of software smes: Exploring the trajectories for sustainable growth," Vision (09722629), vol. 12, no. 2, pp. 47-57, 2008.

[99] E. Maravelakis, N. Bilalis, A. Antoniadis, K. A. Jones, and V. Moustakis, "Measuring and benchmarking the innovativeness of smes: A three-dimensional fuzzy logic approach," Production Planning \& Control, vol. 17, no. 3, pp. 283-292, 2006.
[100] G. Byrne, D. Lubowe, and A. Blitz, "Using a lean six sigma approach to drive innovation," Strategy and Leadership, vol. 35, no. 2, pp. 5-10, 2007.

[101] M. G. Mendonça, V. R. Basili, I. S. Bhandari, and J. Dawson, "An approach to improving existing measurement frameworks," IBM Systems Journal, vol. 37, no. 4, pp. 484-501, 1998.

[102] V. Basili, G. Caldiera, and H. Rombach, "The goal question metric approach," Encyclopedia of Software Engineering, vol. 1, pp. 528-532, 1994.

[103] A. Kleinknecht, K. Van Montfort, and E. Brouwer, "The nontrivial choice between innovation indicators," Economics of Innovation \& New Technology, vol. 11, no. 2, p. 109, 2002.

[104] R. Evangelista, T. Sandven, G. Sirilli, and K. Smith, "Measuring innovation in european industry," International Journal of the Economics of Business, vol. 5, no. 3, pp. 311-333, 1998.

[105] G. Peri, "Determinants of knowledge flows and their effect on innovation," Review of Economics and Statistics, vol. 87, no. 2, pp. 308-322, 2005.

[106] D. J. Smyth, J. M. Samuels, and J. Tzoannos, “Patents, profitability, liquidity and firm size," Applied Economics, vol. 4, no. 2, p. 77, 1972.

[107] S. Juden, "Can software be patented?" Computing \& Control Engineering Journal, vol. 16, no. 4, pp. 16-17, 2005.

[108] A. C. Chatterjee, "Europe struggles over software patents," Spectrum, IEEE, vol. 41, no. 9, pp. 61-63, 2004

[109] G. Aharonian, "Does the patent office respect the software community?" IEEE Softw., vol. 16, no. 4, pp. 87-89, 1999.

[110] A. J. Natoli, "Software patents: beating a dead horse and other important concerns," ser. ELECTRO '96. Professional Program. Proceedings., 1996, pp. 269-276.

[111] Y. Skulikaris, "European software patents," Software, IEEE, vol. 16, no. 6, pp. 109-111, 1999.

[112] K. Nichols, "The age of software patents," Computer, vol. 32, no. 4, pp. 25-31, 1999.

[113] L. McLaughlin, "European union struggles with new rules for software patents," Software, IEEE, vol. 21, no. 5, pp. 101-104, 2004.

[114] D. B. Webber, "Software patents," in Software Engineering Conference, 1997. Proceedings. 1997 Australian, 1997, p. 115.

[115] B. Klemens, "Software patents don't compute: no clear boundary between math and software exists," Spectrum, IEEE, vol. 42, no. 7, pp. 56-58, 2005.

[116] "Organizing for innovation: Consistent innovation message," Strategic Direction, vol. 22, no. 11, pp. 34-36, 2006.

[117] J. Mairesse and P. Mohnen, "Accounting for innovation and measuring innovativeness: An illustrative framework and an application," American Economic Review, vol. 92, no. 2, pp. 226230, 2002.

[118] V. Bush, "Science the endless frontier," Office of Scientific Research and Development, Tech. Rep., 1945.

[119] C. P. Pires, S. Sarkar, and L. Carvalho, "Innovation in services - how different from manufacturing?" Service Industries Journal, vol. 28, no. 10, pp. 1339-1356, 2008.

[120] B. K. Atrostic, "Measuring u.s. innovative activity: Business data at the u.s. census bureau," Journal of Technology Transfer, vol. 33, no. 2, pp. 153-171, 2008.

[121] K. Tajeddini, M. Trueman, and G. Larsen, "Examining the effect of market orientation on innovativeness," Journal of Marketing Management, vol. 22, no. 5/6, pp. 529-551, 2006.

[122] D. A. Aranda and L. M. Molina-Fernández, "Determinants," Industrial Management and Data Systems, vol. 102, no. 5, pp. 289296, 2002.

[123] Z. J. Acs, L. Anselin, and A. Varga, "Patents and innovation counts as measures of regional production of new knowledge," Research Policy, vol. 31, no. 7, pp. 1069-1085, 2002.

[124] J. Tang and C. D. Le, "Multidimensional innovation and productivity," Economics of Innovation \& New Technology, vol. 16, no. 7, pp. 501-516, 2007.

[125] C. Wang and M. I. Kafouros, "What factors determine innovation performance in emerging economies? evidence from china," International Business Review, vol. 18, no. 6, pp. 606-616, 2009.

[126] R. van Solingen and E. Berghout, The Goal/Question/Metric Method: A practical guide for quality improvement of software development. The McGraw-Hill Companies, 1999.

[127] J. McGarry, D. Card, and et al., Practical Software Measurement. Addison Wesley, 2002. 
[128] P. Brereton, B. A. Kitchenham, D. Budgen, M. Turner, and M. Khalil, "Lessons from applying the systematic literature review process within the software engineering domain," Journal of Systems and Software, vol. 80, no. 4, pp. 571-583, 2007.

[129] N. Juristo and A. Moreno, Basics of Software Engineering Experimentation. Kluwer, 2001.

[130] A. Wood, "Managing employees' ideas from where do ideas come?" Journal for Quality E Participation, vol. 26, no. 2, pp. 2226, 2003.

[131] R. Crescenzi, "Innovation and regional growth in the enlarged europe: The role of local innovative capabilities, peripherality, and education," Growth and Change, vol. 36, no. 4, pp. 471-507, 2005.

[132] G. Jordan and E. Segelod, "Software innovativeness: Outcomes on project performance, knowledge enhancement, and external linkages," R and D Management, vol. 36, no. 2, pp. 127-142, 2006.

[133] D. Wan, C. H. Ong, and F. Lee, "Determinants of firm innovation in singapore," Technovation, vol. 25, no. 3, pp. 261-268, 2005.

[134] H. K. Tang, "An inventory of organizational innovativeness," Technovation, vol. 19, no. 1, pp. 41-51, 1998

[135] B. Johansson and H. Lööf, "Innovation activities explained by firm attributes and location," Economics of Innovation and New Technology, vol. 17, no. 6, pp. 533-552, 2008.

[136] M. Swink, "Building collaborative innovation capability," Research Technology Management, vol. 49, no. 2, pp. 37-47, 2006

[137] J. H. Love and S. Roper, "The determinants of innovation: $\mathrm{R}$ and $\mathrm{d}$, technology transfer and networking effects," Review of Industrial Organization, vol. 15, no. 1, pp. 43-64, 1999.

[138] H. Gebauer, R. Krempl, E. Fleisch, and T. Friedli, "Innovation of product-related services," Managing Service Quality, vol. 18, no. 4, pp. 387-404, 2008.

[139] T. Koc, "Organizational determinants of innovation capacity in software companies," Computers $\mathcal{E}$ Industrial Engineering, vol. 53, no. 3, pp. 373-385, 2007.

[140] G. Loblick, "Collaboration is the key to unlocking continuous improvement," Advanced Manufacturing, vol. 10, p. 16, 2008.

[141] M. Hoegl and H. G. Gemuenden, "Teamwork quality and the success of innovative projects: A theoretical concept and empirical evidence," Organization Science, vol. 12, no. 4, pp. 435-449, 2001.

[142] M. Subramaniam and M. A. Youndt, "The influence of intellectual capital on the types of innovative capabilities," Academy of Management Journal, vol. 48, no. 3, pp. 450-463, 2005.

[143] S. Dunphy and P. A. Herbig, "Acceptance of innovations: The customer is the key!" The Journal of High Technology Management Research, vol. 6, no. 2, pp. 193-209, 1995.

[144] R. Beise-Zee and C. Rammer, "Local user-producer interaction in innovation and export performance of firms," Small Business Economics, vol. 27, no. 2-3, pp. 207-222, 2006.

[145] R. H. Searle and K. S. Ball, "Supporting innovation through hr policy: Evidence from the uk," Creativity $\mathcal{E}$ Innovation Management, vol. 12, no. 1, pp. 50-62, 2003.

[146] D. Coronado, M. Acosta, and A. Fernndez, "Attitudes to innovation in peripheral economic regions," Research Policy, vol. 37, no. 6-7, pp. 1009-1021, 2008.

[147] K. Atuahene-Gima and A. Ko, "An empirical investigation of the effect of market orientation and entrepreneurship orientation alignment on product innovation," Organization Science, vol. 12, no. 1, pp. 54-74, 2001.

[148] H.-C. Lai and J. Z. Shyu, "A comparison of innovation capacity at science parks across the taiwan strait: the case of zhangiiang high-tech park and hsinchu science-based industrial park," Technovation, vol. 25, no. 7, pp. 805-813, 2005.

[149] "A framework for innovation: Cracking the code," Strategic Direction, vol. 23, no. 11, pp. 33-35, 2007

[150] P. Sundström and A. Zika-Viktorsson, "Organizing for innovation in a product development project: Combining innovative and result oriented ways of working - a case study," International Journal of Project Management, vol. 27, no. 8, pp. 745-753, 2009.

[151] J. V. Baldridge and R. A. Burnham, "Organizational innovation: Individual, organizational, and environmental impacts," Administrative Science Quarterly, vol. 20, no. 2, pp. 165-176, 1975.

[152] V. Hanna and K. Walsh, "Small firm networks: a successful approach to innovation?" RED Management, vol. 32, no. 3, p. 201, 2002
[153] K. Holt, "Need assessment in product innovation," International Studies of Management $\mathcal{E}$ Organization, vol. 6, no. 4, pp. 26-44, 1976.

[154] W. Bönte and M. Keilbach, “Concubinage or marriage? informal and formal cooperations for innovation," International Journal of Industrial Organization, vol. 23, no. 3-4, pp. 279-302, 2005.

[155] R. Capello, "Spatial and sectoral characteristics of relational capital in innovation activity," European Planning Studies, vol. 10, no. 2, pp. 177-196, 2002.

[156] P. Humphreys, R. McAdam, and J. Leckey, "Longitudinal evaluation of innovation implementation in smes," European Journal of Innovation Management, vol. 8, no. 3, pp. 283-304, 2005.

[157] A. Pirola-Merlo, C. Hrtel, L. Mann, and G. Hirst, "How leaders influence the impact of affective events on team climate and performance in r\&d teams," The Leadership Quarterly, vol. 13, no. 5, pp. 561-581, 2002.

[158] J. A. Aragón-Correa, V. J. Garca-Morales, and E. Cordn-Pozo, "Leadership and organizational learning's role on innovation and performance: Lessons from spain," Industrial Marketing Management, vol. 36, no. 3, pp. 349-359, 2007.

[159] L. Gumusluǒlu and A. Ilsev, "Transformational leadership, creativity, and organizational innovation," Journal of Business Research, vol. 62, no. 4, pp. 461-473, 2009.

[160] S. Radosevic, "Transformation of science and technology systems into systems of innovation in central and eastern europe: the emerging patterns and determinants," Structural Change and Economic Dynamics, vol. 10, no. 3-4, pp. 277-320, 1999.

[161] M. Bastic and G. Leskovar-Spacapan, "What do transition organizations lack to be innovative?" Kybernetes, vol. 35, no. 7-8, pp. 972-992, 2006.

[162] S. Arvanitis, "Explaining innovative activity in service industries: Micro data evidence for switzerland," Economics of Innovation and New Technology, vol. 17, no. 3, pp. 209-225, 2008

[163] C. A. Romano, "Identifying factors which influence product innovation: A case study approach," Journal of Management Studies, vol. 27, no. 1, pp. 75-95, 1990.

[164] "Innovation frustration: Lacking management and metrics," Strategic Direction, vol. 21, no. Copyright 2005, IEE, pp. 36-7, 2005.

[165] H. Grupp, "External effects as a microeconomic determinant of innovation," International Journal of the Economics of Business, vol. 4, no. 2, p. 173, 1997.

[166] "The fuel for productivity," Manufacturing Engineer, vol. 83, no. 6 , pp. 10-11, 2004.

[167] B. Bilbao-Osorio and A. Rodrguez-Pose, "From $r$ and $d$ to innovation and economic growth in the eu," Growth and Change, vol. 35 , no. 4, pp. 434-455, 2004.

[168] A. Conte, "Mapping innovative activity using microdata," Applied Economics Letters, vol. 16, no. 18, pp. 1795-1799, 2009.

[169] M. Dakhli and D. De Clercq, "Human capital, social capital, and innovation: A multi-country study," Entrepreneurship and Regional Development, vol. 16, no. 2, pp. 107-128, 2004.

[170] C. B. Dobni, "The innovation blueprint," Business Horizons, vol. 49 , no. 4 , pp. $329-339,2006$

[171] J. Galende and J. M. de la Fuente, "Internal factors determining a firm's innovative behaviour," Research Policy, vol. 32, no. 5, pp. 715-736, 2003.

[172] D. M. Herold, N. Jayaraman, and C. R. Narayanaswamy, "What is the relationship between organizational slack and innovation?" Journal of Managerial Issues, vol. 18, no. 3, pp. 372-392, 2006.

[173] M. Hoegl, M. Gibbert, and D. Mazursky, "Financial constraints in innovation projects: When is less more?" Research Policy, vol. 37, no. 8, pp. 1382-1391, 2008.

[174] S. G. Green, M. B. Gavin, and L. Aiman-Smith, "Assessing a multidimensional measure of radical technological innovation," IEEE Transactions on Engineering Management, vol. 42, no. 3, pp. 203-214, 1995.

[175] G. L. Adams and B. T. Lamont, "Knowledge management systems and developing sustainable competitive advantage," Journal of Knowledge Management, vol. 7, no. Copyright 2003, IEE, pp. 142-54, 2003.

[176] T. Chun-Yao, "Technological innovation in the bric economies," Research Technology Management, vol. 52, no. 2, pp. 29-35, 2009.

[177] C.-Y. Tseng, "Technological innovation and knowledge network in asia: Evidence from comparison of information and communi- 
cation technologies among six countries," Technological Forecasting and Social Change, vol. 76, no. 5, pp. 654-663, 2009.

[178] R. J. Calantone, S. T. Cavusgil, and Z. Yushan, "Learning orientation, firm innovation capability, and firm performance," Industrial Marketing Management, vol. 31, no. 6, pp. 515-524, 2002.

[179] S. Beugelsdijk, "Entrepreneurial culture, regional innovativeness and economic growth," Journal of Evolutionary Economics, vol. 17, no. 2 , pp. $187-210,2007$

[180] S. C. Chang and M. S. Lee, "The linkage between knowledge accumulation capability and organizational innovation," Journal of Knowledge Management, vol. 12, no. 1, pp. 3-20, 2008.

[181] S. Arvanitis, N. Sydow, and M. Woerter, "Is there any impact of university-industry knowledge transfer on innovation and productivity? an empirical analysis based on swiss firm data," Review of Industrial Organization, vol. 32, no. 2, pp. 77-94, 2008.

[182] H. F. Lin, "Knowledge sharing and firm innovation capability: An empirical study," International Journal of Manpower, vol. 28, no. 3-4, pp. 315-332, 2007.

[183] C. A. Fitzgerald, P. C. Flood, P. O'Regan, and N. Ramamoorthy, "Governance structures and innovation in the irish software industry," The Journal of High Technology Management Research, vol. 19, no. 1, pp. 36-44, 2008.

[184] C. W. Prather, "Use mistakes to foster innovation," Research Technology Management, vol. 51, no. 2, pp. 14-16, 2008.

[185] C. B. Dobni, "Measuring innovation culture in organizations: The development of a generalized innovation culture construct using exploratory factor analysis," European Journal of Innovation Management, vol. 11, no. 4, pp. 539-559, 2008.

[186] M. Bommer and D. Jalajas, "The innovation work environment of high-tech smes in the usa and canada," $R$ and $D$ Management, vol. 32 , no. 5, pp. 379-386, 2002.

[187] A. S. Georgsdottir and I. Getz, "How flexibility facilitates innovation and ways to manage it in organizations," Creativity $\mathcal{E}$ Innovation Management, vol. 13, no. 3, pp. 166-175, 2004.

[188] D. Corkill, "Why can't we do it alone? [innovation management]," Engineering Management, vol. 17, no. 2, pp. 36-39, 2007.

[189] J. Kickul and L. K. Gundry, "Breaking through boundaries for organizational innovation: new managerial roles and practices in e-commerce firms," Journal of Management, vol. 27, no. 3, pp. 347-361, 2001.

[190] K. Talke, "Corporate mindset of innovating firms: Influences on new product performance," Journal of Engineering and Technology Management, vol. 24, no. 1-2, pp. 76-91, 2007.

[191] B. Aschhoff and T. Schmidt, "Empirical evidence on the success of r\&d cooperation - happy together?" Review of Industrial Organization, vol. 33, no. 1, pp. 41-62, 2008.

[192] C. Clegg, K. Unsworth, O. Epitropaki, and G. Parker, "Implicating trust in the innovation process," Journal of Occupational $\mathcal{E}$ Organizational Psychology, vol. 75, no. 4, pp. 409-422, 2002.

[193] C. S. Koberg, N. Uhlenbruck, and Y. Sarason, "Facilitators of organizational innovation: The role of life-cycle stage," Journal of Business Venturing, vol. 11, no. 2, pp. 133-149, 1996.

[194] B. Menguc and S. Auh, "Development and return on execution of product innovation capabilities: The role of organizational structure," Industrial Marketing Management, vol. In Press, Corrected Proof.

[195] M. Basadur and G. A. Gelade, "The role of knowledge management in the innovation process," Creativity $\mathcal{E}$ Innovation Management, vol. 15, no. 1, pp. 45-62, 2006.

[196] S. Bharadwaj and A. Menon, "Making innovation happen in organizations: individual creativity mechanisms, organizational creativity mechanisms or both?" Journal of Product Innovation Management, vol. 17, no. 6, pp. 424-434, 2000.

[197] A. E. Akgün, H. Keskin, and J. Byrne, "Organizational emotional capability, product and process innovation, and firm performance: An empirical analysis," Journal of Engineering and Technology Management, vol. 26, no. 3, pp. 103-130, 2009.

[198] R. A. Baron and J. Tang, "The role of entrepreneurs in firmlevel innovation: Joint effects of positive affect, creativity, and environmental dynamism," Journal of Business Venturing, vol. In Press, Corrected Proof.

[199] E. Mankin, "Measuring innovation performance," Research Technology Management, vol. 50, no. 6, pp. 5-7, 2007.

[200] H. Ernst and U. Lichtenthaler, "Innovation portfolio management: an understudied driver of innovation success?" International Journal of Technology Intelligence and Planning, vol. 5, no.
Copyright 2009, The Institution of Engineering and Technology, pp. 111-17, 2009.

[201] J. Edler and L. Georghiou, "Public procurement and innovationresurrecting the demand side," Research Policy, vol. 36, no. 7, pp. 949-963, 2007.

[202] M. A. Hitt, R. E. Hoskisson, R. D. Ireland, and J. S. Harrison, "Are acquisitions a poison pill for innovation?" Executive (19389779), vol. 5, no. 4, pp. 22-34, 1991.

[203] A. P. De Man and G. Duysters, "Collaboration and innovation: A review of the effects of mergers, acquisitions and alliances on innovation," Technovation, vol. 25, no. 12, pp. 1377-1387, 2005.

[204] L. Yu, "How location clusters affect innovation," MIT Sloan Management Review, vol. 44, no. 1, pp. 16-16, 2002.

[205] D. Tan and P. W. Roberts, "Categorical coherence, classification volatility and examiner-added citations," Research Policy, vol. 39, no. 1, pp. 89-102, 2010.

[206] D. B. Audretsch, "The innovative advantage of us cities," European Planning Studies, vol. 10, no. 2, pp. 165-176, 2002.

[207] D. Z. Chen, W. Y. C. Lin, and M. H. Huang, "Using essential patent index and essential technological strength to evaluate industrial technological innovation competitiveness," Scientometrics, vol. 71, no. 1, pp. 101-116, 2007.

[208] H. Chesbrough, "Managing open innovation," IEEE Engineering Management Review, vol. 32, no. 2, pp. 52-56, 2004.

[209] T. Buganza and R. Verganti, "Life-cycle flexibility: How to measure and improve the innovative capability in turbulent environments," Journal of Product Innovation Management, vol. 23 , no. 5, pp. 393-407, 2006.

[210] C. Beath, "The role of aggregation in the measurement of itrelated organizational innovation," MIS Quarterly, vol. 25, no. 4, pp. 401-401, 2001.

[211] T. Altenburg, H. Schmitz, and A. Stamm, "Breakthrough china's and india's transition from production to innovation," World Development, vol. 36, no. 2, pp. 325-344, 2008.

[212] M. Crosby, "Patents, innovation and growth," Economic Record, vol. 76, no. 234, pp. 255-262, 2000.

[213] R. D. Russell, "Innovation in organizations: Toward an integrated model," Review of Business, vol. 12, no. 2, p. 19, 1990.

[214] S. Mendonça, T. S. Pereira, and M. M. Godinho, "Trademarks as an indicator of innovation and industrial change," Research Policy, vol. 33, no. 9, pp. 1385-1404, 2004.

[215] M. Trajtenberg, "A penny for your quotes: patent citations and the value of innovations," RAND Journal of Economics (RAND Journal of Economics), vol. 21, no. 1, pp. 172-187, 1990.

[216] P. Desyllas and A. Hughes, "The revealed preferences of high technology acquirers: An analysis of the innovation characteristics of their targets," Cambridge Journal of Economics, vol. 33, no. 6 , pp. 1089-1111, 2009.

[217] J. Alcaide-Marzal and E. Tortajada-Esparza, "Innovation assessment in traditional industries. a proposal of aesthetic innovation indicators," Scientometrics, vol. 72, no. 1, pp. 33-57, 2007.

[218] L. Yueh, "Patent laws and innovation in china," International Review of Law and Economics, vol. 29, no. 4, pp. 304-313, 2009.

[219] J. Williams, "Kisa in innovation of new zealand software firms," International Journal of Services Technology and Management, vol. 7 , no. Copyright 2006, The Institution of Engineering and Technology, pp. 154-62, 2006.

[220] S. Goswami and M. Mathew, "Definition of innovation revisited:: An empirical study on indian information technology industry," International Journal of Innovation Management, vol. 9, no. 3, pp. 371-383, 2005.

[221] T. Punter, R. L. Krikhaar, and R. J. Bril, "Software engineering technology innovation - turning research results into industrial success," Journal of Systems and Software, vol. 82, no. 6, pp. 9931003, 2009.

[222] S. J. Conn, M. T. Torkkeli, and I. Bitran, "Assessing the management of innovation with software tools: An application of innovation enterprizer," International Journal of Technology Management, vol. 45, no. 3-4, pp. 323-336, 2009.

[223] K. Honda, T. Sunazuka, and Y. Miyashita, "Software process innovation methodology - multiple approach including iso9001, maturity model and qc technique," NEC Research and Development, vol. 38, no. 1, pp. 96-104, 1997. 


\section{APPENDIX A SEARCH STRINGS}

\begin{tabular}{|c|c|c|}
\hline Database & Search string & Result \\
\hline ScienceDirect & $\begin{array}{l}\text { TITLE-ABSTR-KEY((("innovation") AND ("evaluat" OR "assess" }{ }^{* \prime \prime} \text { OR "measur" }{ }^{* \prime \prime} \text { OR "metric }{ }^{* \prime \prime} \text { OR "indicator" } \\
\left.\left.\text { OR "determinant" OR "driver" OR "key element" OR "attribute" OR "capabilit" } \text { OR "matur" }{ }^{* \prime \prime}\right)\right) \text { Searched } \\
\text { inBusiness management and accounting, Computer Science, Economics, econometrics and finance, Social Science }\end{array}$ & 2920 \\
\hline $\begin{array}{l}\text { Engineering } \\
\text { Village (Inspec } \\
\text { \& Compendex) }\end{array}$ & $\begin{array}{l}\text { ((((("innovation") AND ("evaluat" OR "assess" }{ }^{* \prime \prime} \text { OR "measur" OR "metric }{ }^{* \prime \prime} \text { OR "indicator" OR "determi- } \\
\left.\left.\left.\text { nant" OR "driver" OR "key element" OR "attribute" OR "capabilit*" OR "matur" }{ }^{* \prime \prime}\right)\right)\right) \text { WN KY) AND (JA WN } \\
\text { DT) AND (English WN LA)) NOT (( }\{921\} \text { OR }\{922.2\} \text { OR }\{723.2\} \text { OR }\{914.1\} \text { OR }\{921.6\} \text { OR }\{716\} \text { OR }\{931.1\} \\
\text { OR }\{\text { e0210j\} OR }\{432\} \text { OR }\{409\} \text { OR }\{\text { e0230\} OR }\{443.1\} \text { OR }\{714.2\} \text { OR }\{451.1\}) \text { WN CL)) }\end{array}$ & 574 \\
\hline Scopus & 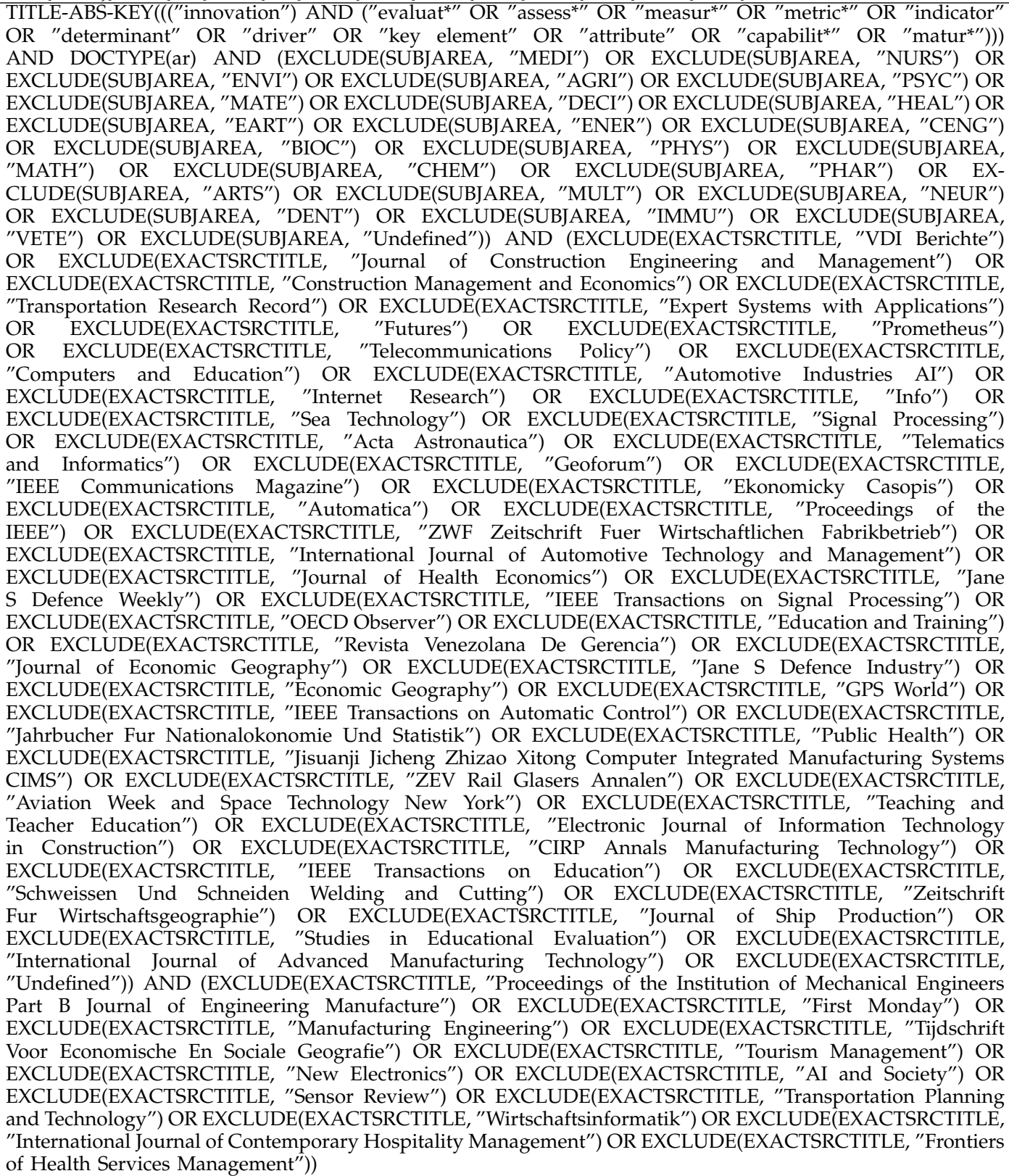 & 6682 \\
\hline
\end{tabular}


.concluded from previous page

\begin{tabular}{|c|c|c|}
\hline Database & Search string & Result \\
\hline IEEE & 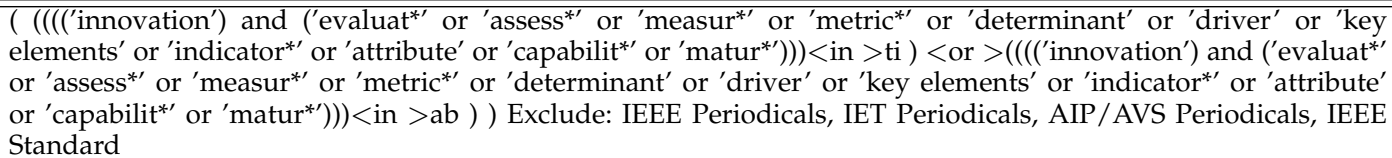 & 16 \\
\hline $\mathrm{ACM}$ & 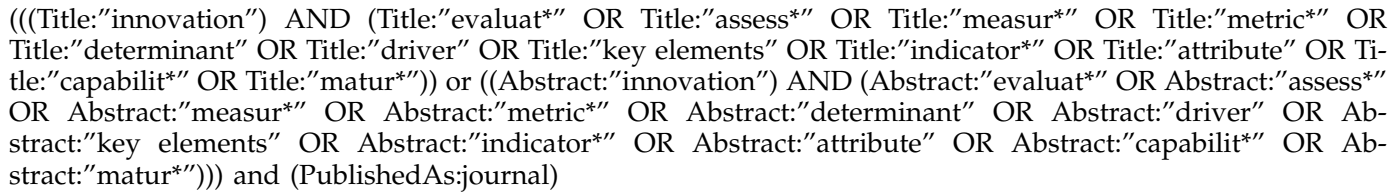 & 3 \\
\hline BSP & 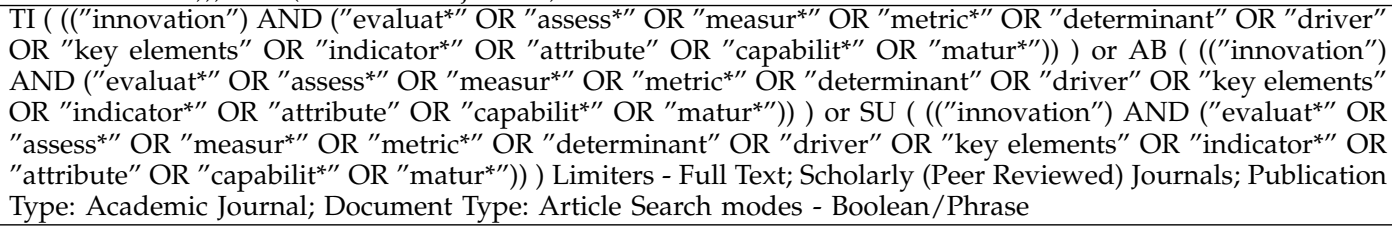 & 3402 \\
\hline
\end{tabular}




\section{APPENDIX B DEFINITIONS OF INNOVATION}

\begin{tabular}{|c|c|c|}
\hline & Source & Definitions \\
\hline 1 & [64] & 'Innovation has two parts: the generation of an idea and the conversion of that idea into a useful application.' \\
\hline 2 & [79] & 'Innovations are generated as products move through various processes from the research laboratory to the factory.' \\
\hline 3 & [57] & $\begin{array}{l}\text { 'Innovation is a process that begins with an invention, proceeds with the development of the inventions, and results } \\
\text { in the introduction of a new product, process or service to the market-place.' }\end{array}$ \\
\hline 4 & [73] & 'Innovation is the successful exploitation of new ideas.' \\
\hline 5 & [47] & $\begin{array}{l}\text { 'Product innovation is a continuous and cross-functional process involving and integrating a growing number of } \\
\text { different competencies inside and outside the organisational boundaries. Simply put, it is the process of transforming } \\
\text { business opportunities into tangible products and services.' }\end{array}$ \\
\hline 6 & [81] & $\begin{array}{l}\text { 'Innovation is defined as the adoption of an idea or behavior whether a system, policy, program, device, process, } \\
\text { product or service that is new to the adopting organization.' }\end{array}$ \\
\hline 7 & [45] & $\begin{array}{l}\text { 'Innovation behavior can be defined as all individual actions directed at the generation, introduction and application } \\
\text { of beneficial novelty at any organization level.' }\end{array}$ \\
\hline 8 & [63] & 'Innovation refers to a process that begins with a novel idea and concludes with market introduction.' \\
\hline 9 & [82] & 'Innovation is an idea, practice or object that is perceived as new to an individual or another unit of adoption.' \\
\hline 10 & [86] & 'Innovation refers to the creation of new product within the firm.' \\
\hline 11 & [55] & $\begin{array}{l}\text { 'Organizational innovation has been consistently defined as the adoption of an idea of behavior that is new to the } \\
\text { organization. The innovation can either be a new product, a new service, a new technology, or a new administrative } \\
\text { practice.' }\end{array}$ \\
\hline 12 & [66] & $\begin{array}{l}\text { 'Innovation is usually understood as the introduction of something new or significantly improved, like products } \\
\text { (goods or services) or processes.' }\end{array}$ \\
\hline 13 & [72] & $\begin{array}{l}\text { 'Innovation can be seen as representing a change in the status quo and has been defined as involving the discovery } \\
\text { of new things and the commercialization such discoveries.' }\end{array}$ \\
\hline 14 & [71] & 'Innovations are new ideas that are valued in the marketplace.' \\
\hline 15 & [68] & $\begin{array}{l}\text { 'Innovation is defined as "a technologically new or significantly enhanced product compared to the firm's previous } \\
\text { product" which has been commercialized on the market.' }\end{array}$ \\
\hline 16 & [130] & $\begin{array}{l}\text { 'Creativity is the recognition of an opportunity of the inspiration that develops an idea. Innovation is the implemen- } \\
\text { tation of all ideas - big and small.' }\end{array}$ \\
\hline 17 & [80] & $\begin{array}{l}\text { 'Product innovation is defined here as the introduction of technologically new (or significantly improved) products } \\
\text { which are new to the firm (it does not have to be new to the world).' }\end{array}$ \\
\hline 18 & [52] & $\begin{array}{l}\text { 'Re-innovation is defined as the part of new product development which studies the extension of existing innovation, } \\
\text { which can only happen after the first generation of a new product is launched.' }\end{array}$ \\
\hline 19 & [54] & $\begin{array}{l}\text { 'Innovation understood as a process entails the generation, development, adoption, implementation and eventual } \\
\text { termination of a new idea or behavior.' }\end{array}$ \\
\hline 20 & [67] & $\begin{array}{l}\text { 'Innovation is an iterative process initiated by the perception of a new market and/or new service opportunity for a } \\
\text { technology-based invention which leads to development, production, and marketing task striving for the commercial } \\
\text { success of the invention. Innovativeness is the capacity of new innovation to create a paradigm shift in the science and } \\
\text { technology and/or market structure in an industry. Innovativeness is the capacity of a new innovation to influence } \\
\text { the firm's existing marketing resources, technological resources, skill, knowledge, capabilities, or strategies.' }\end{array}$ \\
\hline 21 & [49] & $\begin{array}{l}\text { 'Innovation is defined as all intentional results of action (products or processes) that bring about perceived changes } \\
\text { within the organization.' }\end{array}$ \\
\hline 22 & [75] & $\begin{array}{l}\text { 'A product innovation can be described as a novel product, which is clearly different from the previous one. Radical } \\
\text { innovations that are of interest at this point are characterized by a new technological basis and a novel utility experience } \\
\text { to the customer.' }\end{array}$ \\
\hline 23 & [56] & $\begin{array}{l}\text { 'Innovations vary in complexity and can range from minor changes to existing products, processes, or services to } \\
\text { breakthrough products, and processes or services that introduce first-time features or exceptional performance.' }\end{array}$ \\
\hline 24 & [70] & $\begin{array}{l}\text { 'Successful launching of a product/process or a service that is either new or incorporates new or additional scientific } \\
\text { output, known as innovation.' }\end{array}$ \\
\hline 25 & [12] & $\begin{array}{l}\text { 'Innovation is the generation, adaptation of an idea or behavior, new to the adopting organisation. The first successful } \\
\text { application of a product or process. Innovation is conceived as a means of changing an organization, either as a } \\
\text { response to changes in the external environment, or as a pre-emptive action to influence the environment. Innovation } \\
\text { is the process of successfully creating something new that has significant value to the relevant unit of adoption. A } \\
\text { radical innovation is a product, process or service with either unprecedented performance features or familiar features } \\
\text { that offers significant improvements in performance or cost that transform existing markets or create new ones. A } \\
\text { successfully exploited radical new product, process, or concept that significantly transforms the demand and needs of } \\
\text { an existing market or industry, disrupts its former key players and creates whole new business practices or markets } \\
\text { with significant societal impact.' }\end{array}$ \\
\hline
\end{tabular}

continued on next page.. 
..concluded from previous page

\begin{tabular}{|c|c|c|}
\hline & Source & Definitions \\
\hline 26 & [15] & $\begin{array}{l}\text { 'Organizational innovation was conceptualized as the tendency of the organization to develop new or improved } \\
\text { products or services and its success in bringing those products or services to the market. Innovation is defined as the } \\
\text { successful implementation of creative ideas within an organization.' }\end{array}$ \\
\hline 27 & [131] & $\begin{array}{l}\text { 'Innovation is a fundamental process for overcoming the rigidity of mass production and transiting toward an } \\
\text { increasingly quality-based competitive system.' }\end{array}$ \\
\hline 28 & [58] & $\begin{array}{l}\text { 'Innovation can take several forms: product innovation: changes in the things (products/services) which an organi- } \\
\text { zation offers, process innovation: changes in the ways in which they are created and delivered, position innovation: } \\
\text { changes in the context in which the products/services are introduced, paradigm innovation: changes in the underlying } \\
\text { mental models which frame what the organization does.' }\end{array}$ \\
\hline 29 & [69] & 'An innovation is defined by the first economic utilization or application of an invention to achieve corporate goals.' \\
\hline 30 & [3] & $\begin{array}{l}\text { 'Innovative capability is defined as the capacity of developing new products satisfying market needs, the capacity of } \\
\text { applying appropriate process technologies to produce these new products, the capacity of developing and adopting } \\
\text { new product and processing technologies to satisfy the future needs, the capacity of responding to accidental } \\
\text { technology activities and unexpected opportunities created by the competitors.' }\end{array}$ \\
\hline 31 & [59] & $\begin{array}{l}\text { 'Innovation as new products, processes and organisational arrangements that are new to the firm rather than new to } \\
\text { the world.' }\end{array}$ \\
\hline 32 & [77] & $\begin{array}{l}\text { 'Radical innovations are innovations that 'involve the discovery of new technologies and the creation of new markets'. } \\
\text { Radical innovations are defined as those involving the creation of new technologies and/or markets and that 'are } \\
\text { conceptual shifts that make history'.' }\end{array}$ \\
\hline 33 & [132] & $\begin{array}{l}\text { Product innovativeness differs from the term product innovation, to mean the degree of newness in 'the development } \\
\text { of new products changes in design of established products, or use of new materials or components in the manufacture } \\
\text { of established products.' }\end{array}$ \\
\hline 34 & [50] & $\begin{array}{l}\text { Distinction between invention and innovation is the former referring to the first oc } \\
\text { product or process, while the latter to its first commercialization. Software innovativ } \\
\text { aspects of the product, such as its features . . the impression of its newness, the nov }\end{array}$ \\
\hline 35 & [84] & of knowle \\
\hline 36 & [87] & $\begin{array}{l}\text { 'Product innovation relates to the introduction into the market of any new or significant improved products (goods } \\
\text { or services). Process innovation: relates to the introduction of any new or significantly improved production process } \\
\text { (but not delivery, unless this is integral to the process of production/ delivery). Delivery innovation: relates to the } \\
\text { development of changes in how the enterprise delivers its products (goods or services) to its customers. Examples } \\
\text { include introduction of just-in-time delivery, consumer e-commerce, introduction of new or significantly improved } \\
\text { home shopping services. Strategic innovation: relates to the implementation of new or significantly modified business } \\
\text { strategies. Examples include targeting different markets, implementing new or significantly modified missions. } \\
\text { Managerial innovation: relates to the implementation of new or significantly modified managerial techniques. } \\
\text { Examples include the introduction of knowledge management practices, quality circles. Marketing innovation: relates } \\
\text { to the implementation of new or significantly modified marketing strategies and concepts. Examples include the } \\
\text { introduction of new or significantly improved marketing methods.' }\end{array}$ \\
\hline 37 & [74] & $\begin{array}{l}\text { 'Incremental innovations involve relatively minor changes in technology and provide relatively low incremental } \\
\text { customer benefits per dollar. Markets breakthroughs are based on core technology that is similar to existing products } \\
\text { but provide substantially higher customer benefits per dollar. Technological breakthroughs adopt a substantially } \\
\text { different technology than existing products but do not provide superior customer benefits per dollar. Radical } \\
\text { innovations involve substantially new technology and provide substantially greater customer benefits per dollar.' }\end{array}$ \\
\hline 38 & [5] & $\begin{array}{l}\text { ion = Invention + commercialization. In situations where the innovation relates to an internal activity, the } \\
\text { mplementation" can be substituted for "commercialization.' }\end{array}$ \\
\hline 39 & [133] & $\begin{array}{l}\text { 'Innovation as a process that involves the generation, adoption, implementation and incorporation of new ideas, } \\
\text { practices or artifacts within the organization.' }\end{array}$ \\
\hline 40 & [134] & fful use.' \\
\hline 41 & [135] & novation processes generate new products and new routines of an innovating firm.' \\
\hline
\end{tabular}




\begin{tabular}{|c|c|}
\hline \multicolumn{2}{|c|}{ Strategy* } \\
\hline $\begin{array}{l}\text { Innovation strategy (it designates to what degree and in what way a } \\
\text { firm uses innovation to perform a business strategy and to develop } \\
\text { its performance) [3] [47] [149] }\end{array}$ & Strategic orientation [73] \\
\hline Strategic attention (existence of concrete objective on innovation) [45] & Strategic leadership [73] \\
\hline $\begin{array}{l}\text { Innovation vision (vision based on factual customer and market } \\
\text { insights with few focused and explicit objectives based on under- } \\
\text { standing of market needs and own capabilities) [100] }\end{array}$ & \\
\hline $\begin{array}{l}\text { Analysis of strategy (provides information about trends and events } \\
\text { in their environment and facilitates to recognise innovation opportu- } \\
\text { nities) [3] }\end{array}$ & Aggressiveness of strategy [3] \\
\hline $\begin{array}{l}\text { Futurity of strategy (concerns the innovation opportunities based } \\
\text { on the determination of future changes and developments in the } \\
\text { environment as well as estimation of future market needs) [3] }\end{array}$ & Analysis of strategy [3] \\
\hline $\begin{array}{l}\text { Proactiveness of strategy (the ability to create new opportunities or } \\
\text { the ability to recognise or anticipate an act on opportunities) [3] }\end{array}$ & Defensiveness of strategy [3] \\
\hline $\begin{array}{l}\text { Riskiness of strategy (encourage the behaviour of market opportunity } \\
\text { seeking and transforming of these opportunities into innovative } \\
\text { products and processes) [3] }\end{array}$ & Futurity of strategy [3] \\
\hline $\begin{array}{l}\text { (-) Aggressiveness of strategy (emphasises a combative posture in } \\
\text { exploiting market opportunities and relates to firm advances to be- } \\
\text { come the first mover in the market place to develop radical innovation }\end{array}$ & Pro-activeness of strategy [3] \\
\hline $\begin{array}{l}\text { before competitors even at expense of profitability and to give priority } \\
\text { to innovation projects that involve high levels of risk and returns) [3] }\end{array}$ & \\
\hline $\begin{array}{l}\text { (-) Defensiveness of strategy (concerns the firms need to defend it } \\
\text { current position in the market place) [3] }\end{array}$ & Riskiness of strategy [3] \\
\hline Clear vision and goals with freedom realisation [150] & \\
\hline
\end{tabular}

\begin{tabular}{ll}
\hline \hline & \multicolumn{1}{c}{ Networking* } \\
\hline Determinants & Metrics \\
\hline Strength of ties with clients [87] & Ecosystem relationships [24] \\
Environmental input from the community and other organisations & Clusters of suppliers and customers [75] \\
[151] & \\
Networking [152] & \\
External contacts (frequency of having contacts with suppliers, cus- \\
tomers and people from other companies in the same market) [45] \\
Technology incubation programme [153] \\
Informal co-operation [154] \\
Networking (inter firm relationship) [137] \\
Relational capital [155]
\end{tabular}

\begin{tabular}{ll}
\hline \hline & \multicolumn{1}{c}{ Leadership* } \\
\hline Determinants & Metrics \\
\hline $\begin{array}{l}\text { Leadership (competent, visionary, committed, knowledgeable and } \\
\text { outward looking leaders who excel at inspiring employees) [53] [94] }\end{array}$ & $\begin{array}{l}\text { Number/percentage of members from technical functions/product } \\
\text { development in the main and subsidiary/divisional boards [94] }\end{array}$ \\
$\begin{array}{l}\text { [47] [72] [156] [157] } \\
\text { Transformational leadership (which transforms followers' personal } \\
\text { values and self-concepts, moves them to higher levels of needs and } \\
\text { aspirations and raises their performance expectations) [15] [158] [159] }\end{array}$ & $\begin{array}{l}\text { Percentage of employee aware of, sharing the innovation policies and } \\
\text { Leadership commitment [100] }\end{array}$ \\
& $\begin{array}{l}\text { Percentage of executives' time spent on strategic innovation rather } \\
\text { than day-to-day operations [14] } \\
\text { Percentage of managers with training in the concepts and tools of } \\
\text { innovation [14] } \\
\text { Number of times during the past 5, 10, and 20 years in which senior } \\
\text { management has redefined the company's core business [14] }\end{array}$ \\
\hline \hline
\end{tabular}




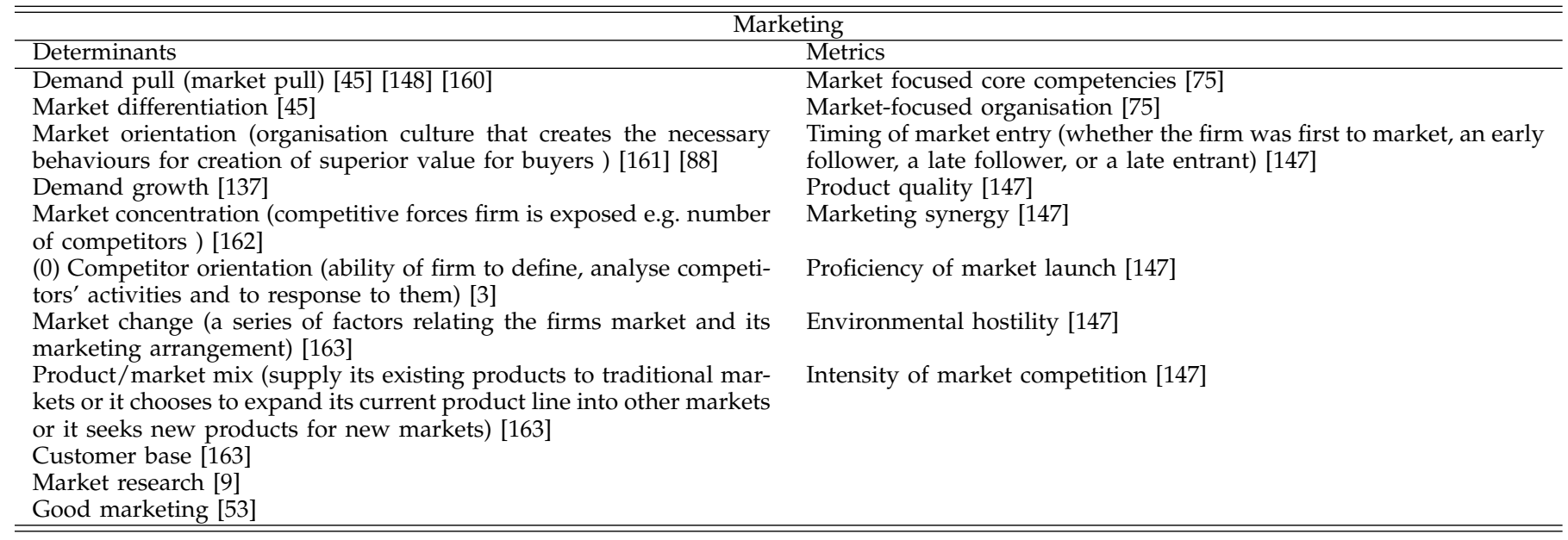

\begin{tabular}{|c|c|}
\hline \multicolumn{2}{|c|}{ Technology } \\
\hline Determinants & Metrics \\
\hline Technology $[139,151]$ & Technical performance [94] \\
\hline Specialised knowledge and experience in science and engineer [23] & Percentage of products on CAD database [94] \\
\hline IT investments [5] & Number of licenses in/out over the last 3 years [94] \\
\hline $\begin{array}{l}\text { Technology diversification (diversity in the knowledge system and } \\
\text { principles underlying the nature of products and their methods of } \\
\text { production. Expansion of corporations technological competence into } \\
\text { a broader range of technical and discipline areas) [5] }\end{array}$ & Self-citing ration [153] \\
\hline $\begin{array}{l}\text { (0)technological orientation ( acquiring technical knowledge to per- } \\
\text { ceive technological opportunities before competitors) [1] }\end{array}$ & $\begin{array}{l}\text { Technological uncertainty (amount of technological uncertainty that } \\
\text { characterised the project) [154] }\end{array}$ \\
\hline $\begin{array}{l}\text { Technology capabilities (firm's technological competencies, derived } \\
\text { from in-house R\&D) [34, 152] }\end{array}$ & $\begin{array}{l}\text { Technical inexperience (the firm's inexperience and lack of knowledge } \\
\text { about the project's required scientific and technical expertise) [154] }\end{array}$ \\
\hline Technology adoption [119] & $\begin{array}{l}\text { Firm's technical capability (the adequacy of the firm's technical } \\
\text { capability supports the project's complexity) [51] }\end{array}$ \\
\hline $\begin{array}{l}\text { Product life-cycle[151] } \\
\text { Information technology (for better information sharing and systemati- } \\
\text { cally gathering information on competitor services and new customer } \\
\text { needs) [128] }\end{array}$ & \\
\hline
\end{tabular}

\begin{tabular}{lc}
\hline \hline & Policy \\
\hline Public policy [67] & $\begin{array}{l}\text { Government regulation effect (the degree of negative effects associ- } \\
\text { ated with government regulations) [92] }\end{array}$ \\
\hline \hline
\end{tabular}

\begin{tabular}{ll}
\hline \hline & Tool support \\
\hline Determinants & Metrics \\
\hline Funnel tools (tool support for developing concept maps and defini- & Tools for innovation project management [73] \\
tion of requirements for customer acceptance)[138] & \\
Systems and tools [94] & \\
\hline \hline
\end{tabular}

\begin{tabular}{ll}
\hline \hline & Research \& development \\
\hline Determinants & Metrics \\
\hline R\&D performance [164] & R\&D accounting data (expenditure on R\&D) [25] [165] \\
R\&D investment (expenditures) [55] [13] [57] [125] [166] [167] [168] & R\&D Intensity (percent of annual sales spent on R\&D) [147] [167] \\
[104] [87] [119] [163] & $\begin{array}{l}\text { Expenditure of R\&D as a percentage of GNP [169] } \\
\text { R\&D [170] }\end{array}$ \\
Experimentation [170] & $\begin{array}{l}\text { R\&D intensity (R\&D employment in the plan as a percentage of whole } \\
\end{array}$ \\
\hline \hline
\end{tabular}




\begin{tabular}{|c|c|}
\hline \multicolumn{2}{|c|}{ Alignment } \\
\hline Determinants & Metrics \\
\hline Alignment (six alignment factors for alignment around innovation) & Corporate fit (the degree to which the project objectives fit in with \\
\hline Market and entrepreneurial orientation alignment [147] & $\begin{array}{l}\text { Project mission (the level of clarity with which the project mission is } \\
\text { defined from start to end)[92] }\end{array}$ \\
\hline $\begin{array}{l}\text { Co-alignment (between employee-centric behaviours and the compet- } \\
\text { itive environment, organisation's ability to constantly re- or self-align } \\
\text { itself with change is the key to fostering ongoing innovation)[170] } \\
\text { Alignment throughout the organisation and its extended enterprise } \\
\text { [100] }\end{array}$ & \\
\hline
\end{tabular}

\begin{tabular}{ll}
\hline \hline & Organisational resources \\
\hline Determinants & Metrics \\
\hline Organisation capital [142] & Percentage of projects delayed, cancelled due to lack of funding [94] \\
Human capital [142] [169] & Percentage of projects on which specific tools are applied [94] \\
Social capital [80] [142] & Certified processes [94] \\
Internal sources [171] & Capital output ratio [70] \\
Basic research infrastructure [148] & Capital per Employee [70] \\
Social capital (trust and associational activity) [169] & \\
(-) Social capital (norms of civic behaviour) [169] & \\
Organisation capabilities [100] & \\
Innovation infrastructure (employee skills and learning, technological \\
and financial support) [170] \\
Presence of organisational resources [133] \\
Strategic capabilities [77] \\
Organisational slack [172] \\
Adequate resources [89] \\
Resource orientation [88]
\end{tabular}

\begin{tabular}{ll}
\hline \hline & Financial \\
\hline Determinants & Metrics \\
\hline Financial resource constraints [173] & $\begin{array}{l}\text { Innovation cost (cost of spending on design and engineering and } \\
\text { above all on production investment connected with the introduction } \\
\text { and diffusion of innovation processes) [94] } \\
\text { Technology cost (radical innovations require more resources to suc- } \\
\text { cessfully commercialise. Thus the decision to do research in certain } \\
\text { knowledge areas or to implement certain technologies will incur this } \\
\text { cost) [174] } \\
\text { Non-specific investments [75] } \\
\text { Total innovation expenditure (covers both R\&D and non R\&D inno- } \\
\text { vation expenditure) [103] }\end{array}$ \\
$\begin{array}{ll}\text { Finance (funding the innovation project) [160] } \\
\text { (-)The degree of indebtedness of the company [146] }\end{array}$ & \begin{tabular}{l} 
(-)The potential cost of the innovation [146] \\
\hline \hline
\end{tabular}
\end{tabular}

\begin{tabular}{l}
\hline \hline \multicolumn{1}{c}{ Empowerment } \\
\hline Determinants \\
\hline Agile decision making (gathering and using various levels of infor- \\
mation and involving diverse people to make a decision)[64] \\
Empowerment (skilled people have ownership to innovate in their \\
area) [64] [156] [170] \\
Meaningful work (work that each person knows has impact in the \\
organisation and with customer) [64] \\
Job challenge [45] \\
Autonomy (employees are allowed to decide themselves how to do \\
a job') [45]
\end{tabular}




\begin{tabular}{|c|c|}
\hline \multicolumn{2}{|c|}{$\overline{\text { Knowledge management }}$} \\
\hline Determinants & Metrics \\
\hline Knowledge management system [175] & Citation [24] [176] [177] \\
\hline Organisational learning capabilities [64] [156] [158] [170] [175] [178] & Life-long learning [75] \\
\hline Knowledge management policies and strategies [87] [122] & Knowledge flow [179] \\
\hline $\begin{array}{l}\text { Organisational capital (aspects of explicit knowledge that may be } \\
\text { documented and kept written)[80] }\end{array}$ & $\begin{array}{l}\text { Number and type of conferences they have sponsored and } \\
\text { attended[24] }\end{array}$ \\
\hline Knowledge flow [76] & $\begin{array}{l}\text { Knowledge repository (number of patents brought into the repository, } \\
\text { for codified knowledge) [73] }\end{array}$ \\
\hline $\begin{array}{l}\text { Technological potential (scientific, technological and organisational } \\
\text { knowledge relevant to a firm's innovative activity) [162] }\end{array}$ & $\begin{array}{l}\text { Measures of customer information contacts (the extent the organisa- } \\
\text { tion makes use of customers as source of information) [73] }\end{array}$ \\
\hline Ideas [149] & $\begin{array}{l}\text { Measure of the linkage that the innovating groups maintains the } \\
\text { external organisations and resources [73] }\end{array}$ \\
\hline $\begin{array}{l}\text { Innovation influence (knowledge management, sphere of influence) } \\
\text { [170] }\end{array}$ & Measures of internal information gathering processes [73] \\
\hline Variety of knowledge sources [87] & $\begin{array}{l}\text { Percentage of designers/engineers trained to design for manufacture } \\
\text { [94] }\end{array}$ \\
\hline Types of knowledge exchanged with clients (tacit or explicit) [87] & Percentage of team leaders trained in creativity techniques [94] \\
\hline Capability of knowledge accumulation [180] & Percentage of designer/engineers with access to CAD screens [94] \\
\hline Knowledge and technology transfer (KTT) [181] & Knowledge sharing [182] \\
\hline Knowledge diffusion [177] & \\
\hline Firm's absorptive capacity [119] & \\
\hline Internal knowledge sources [119] & \\
\hline External knowledge sources [119] & \\
\hline Training and education of personnel [138] [183] & \\
\hline $\begin{array}{l}\text { Information flow (flow of information inside and outside the organ- } \\
\text { isation) [73] }\end{array}$ & \\
\hline Idea generation [139] & \\
\hline Knowledge sharing [182] & \\
\hline
\end{tabular}

\begin{tabular}{|c|c|}
\hline \multicolumn{2}{|c|}{ Culture } \\
\hline Culture and climate [47] [149] [156] & KEYS survey instrument [186] \\
\hline Entrepreneurial culture [179] & Entrepreneurial orientation [147] \\
\hline Culture (Hofstede) [66] & $\begin{array}{l}\text { Peer support (the degree of support for the project from other groups } \\
\text { and individuals within the firm) [92] }\end{array}$ \\
\hline
\end{tabular}




\begin{tabular}{|c|c|}
\hline \multicolumn{2}{|c|}{ Management } \\
\hline Determinants & Metrics \\
\hline Managerial roles [189] & $\begin{array}{l}\text { Business inexperience (the firm's inexperience and lack of knowledge } \\
\text { about the project's required business practices) [174] }\end{array}$ \\
\hline Corporate mindset [190] & Management involvement [147] \\
\hline Good management [89] [156] & \\
\hline Willingness to abandon investments [75] & \\
\hline Process [149] & \\
\hline Management of technical aspects [89] & \\
\hline Willingness to cannibalise [74] & \\
\hline (-) Where other business executives think much too narrowly about & \\
\hline R\&D and the form of innovation partnerships [188] & \\
\hline (-) More confusion over the management methods needed to deliver & \\
\hline continuous value from external or open innovation activities, espe- & \\
\hline $\begin{array}{l}\text { cially when they involve tens if not hundreds, of business partners } \\
\text { [188] }\end{array}$ & \\
\hline
\end{tabular}

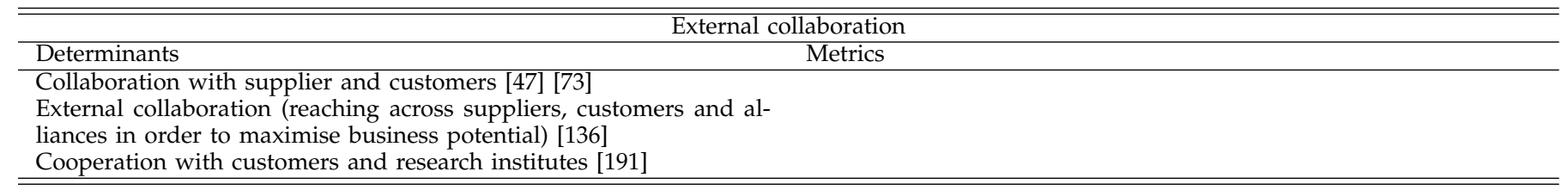

\begin{tabular}{|c|c|}
\hline \multicolumn{2}{|c|}{ Risk } \\
\hline Determinants & Metrics \\
\hline Climate of smart risk taking [149] & Risk / Return balance [73] \\
\hline Freedom and risk taking [184] & \\
\hline Willingness to take risks [133] & \\
\hline
\end{tabular}

\begin{tabular}{|c|}
\hline Trust \\
\hline $\begin{array}{ll} & \text { Metrics }\end{array}$ \\
\hline $\begin{array}{l}\text { Trust that benefit (when employees believe that they will share the } \\
\text { benefits they make more suggestions, but this belief has no effect on } \\
\text { whether their ideas are actually implemented) [192] } \\
\text { Trust that heard (employee trust that the organisation will listen to } \\
\text { them has a direct effect on ideas implementation but not on the } \\
\text { suggestions they make) [192] } \\
\text { Trust \& openness (acknowledge the mistakes and discuss them and } \\
\text { focus on learning)[184] }\end{array}$ \\
\hline
\end{tabular}




\begin{tabular}{|c|c|}
\hline \multicolumn{2}{|c|}{ Communication } \\
\hline Determinants & Metrics \\
\hline Communication [6] [47] [89] [150] & $\begin{array}{l}\text { Communication (facilitates the dispersion of ideas within an } \\
\text { organisation)[73] }\end{array}$ \\
\hline (-) Poor communication and knowledge transfer [47] & Communication cost per employee [70] \\
\hline & Communication cost per output [70] \\
\hline
\end{tabular}

\begin{tabular}{lc}
\hline \hline & Organisation Structure \\
\hline Determinants & Metrics \\
\hline Structural characteristics of organisation, e.g. size and complexity & \\
[151] & \\
Organisation structure [54] [180] [193] [194] & \\
Decentralised structure [133] & \\
Structure and performance [47] & \\
\hline \hline
\end{tabular}

\begin{tabular}{lc}
\hline \hline & \multicolumn{1}{c}{ Individual } \\
\hline Determinants & \\
\hline Individual [151] & \\
Thinking skills [195] & \\
Individual creativity mechanism [196] & \\
Emotional capability [197] & \\
Entrepreneurship [198] & \\
\hline \hline
\end{tabular}

\begin{tabular}{ll}
\hline \hline & Commitment \\
\hline Determinants & Metrics \\
\hline $\begin{array}{l}\text { Organisational creativity mechanism [196] } \\
\begin{array}{l}\text { Innovation intent (propensity and architecture, employee con- } \\
\text { stituency) [170] }\end{array}\end{array}$ & \\
\hline \hline
\end{tabular}

\begin{tabular}{lc}
\hline \hline & Intellectual property \\
\hline Determinants & Metrics \\
\hline Patented inventions [57] & \\
The input of prior innovations [55] & \\
\hline \hline
\end{tabular}

\begin{tabular}{ll}
\hline \hline & Planning \\
\hline Determinants & Metrics \\
\hline Planned innovation [89] & $\begin{array}{l}\text { Project portfolio size (the number of ongoing projects at any given } \\
\text { time) [92] } \\
\text { Commercial and technical fit (the degree of association between the } \\
\text { projects commercial and the technological aspects) [92] }\end{array}$ \\
$\begin{array}{l}\text { Business planning [64] [47] } \\
\text { Innovation portfolio management [200] }\end{array}$ \\
$\begin{array}{l}\text { (-) Poor portfolio management [47] } \\
\text { Competitive edge [163] }\end{array}$ \\
\hline \hline
\end{tabular}

\begin{tabular}{lc}
\hline \hline & Acquisition \& alliance \\
\hline Determinants & Metrics \\
\hline Public procurement [201] & \\
Acquisition [202] & \\
(0/-) Mergers and acquisition [203] & \\
Technology acquisition [168] & \\
Technology access through alliances [160] & \\
Alliances [203] & \\
\hline \hline
\end{tabular}

\begin{tabular}{ll}
\hline \hline & Size \\
\hline Determinants & Metrics \\
\hline Firm size [54] [81] [149] [146] [162] [106] & Firm Size [147] \\
(0) Firm size [75] [119] [137] & \\
\hline \hline
\end{tabular}




\section{C.2 External Determinants}

\begin{tabular}{ll}
\hline \hline Determinants & Metrics \\
\hline Population [71] & Economic structure [167] \\
Location cluster [204] & Human development index [169] \\
Technological opportunities [146] & Market competition (the degree of market competition for the project) \\
Foreign Direct Investment (FDI) [125] & Science and technology availability (the degree to which science and \\
& technology needed for the project is readily available) [92] \\
International trade [125] & \\
$\begin{array}{l}\text { Knowledge spill-overs make location important [206] } \\
\text { A local context that encourages investment in innovation-related } \\
\text { activity [148] }\end{array}$ & \\
Public R\&D support [13] & \\
Higher education R\&D investment [167] & \\
Extramural R\&D [119] & \\
\hline \hline
\end{tabular}


APPENDIX D

DETERMINANTS AND INNOVATION ACTIVITIES

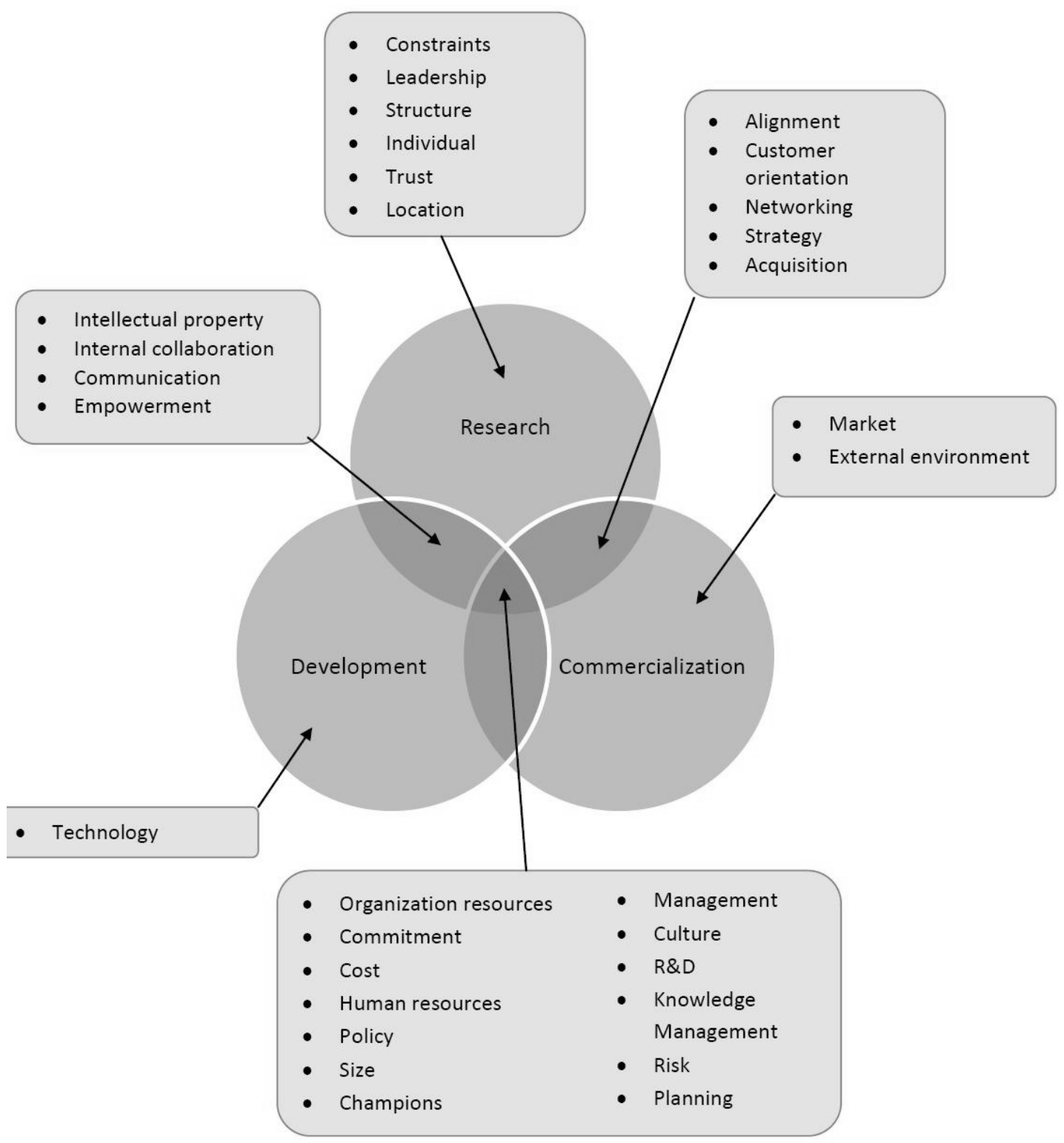




\section{APPENDIX E}

\section{METRICS FOR INNOVATION FROM SOFTWARE RELATED STUDIES}

\begin{tabular}{|c|c|}
\hline Metrics & Source \\
\hline Products new to the world, developed using new or significantly improved technology & [98] \\
\hline Products new to the nation, developed using new or significantly improved technology & [98] \\
\hline Products new to the firm, developed using new or significantly improved technology & [98] \\
\hline Activities new to the world, developed using new or significantly improved technology & [98] \\
\hline Activities new to the nation, developed using new or significantly improved technology & [98] \\
\hline Activities new to the firm, developed using new or significantly improved technology & [98] \\
\hline $\begin{array}{l}\text { Whether or not a firm had accomplished at least one major product innovation during the } 3 \text { years } \\
\text { preceding the survey }\end{array}$ & [13] \\
\hline Number of patents held & [13] \\
\hline Product innovation index & [13] \\
\hline Market orientation & [147] \\
\hline Entrepreneurial orientation & [147] \\
\hline New product performance & [147] \\
\hline Timing of market entry & [147] \\
\hline Product quality & [147] \\
\hline Marketing synergy & [147] \\
\hline Proficiency of market launch & [147] \\
\hline Management involvement & [147] \\
\hline Importance given to innovation in human resource management & [147] \\
\hline Environmental hostility & [147] \\
\hline Intensity of market competition & [147] \\
\hline Firm size & [147] \\
\hline R\&D intensity (percent of annual sales spent on R\&D) & [147] \\
\hline Number of R\&D personnel & [147] \\
\hline Organisational innovation & [15] \\
\hline Customer orientation & [3] \\
\hline Competitor orientation & [3] \\
\hline Inter-functional coordination & [3] \\
\hline Technological orientation & [3] \\
\hline Aggressiveness & [3] \\
\hline Analysis & [3] \\
\hline Defensiveness & [3] \\
\hline Futurity & [3] \\
\hline Proactiveness & [3] \\
\hline Riskiness & [3] \\
\hline Innovation capability & [3] \\
\hline Innovation success & [3] \\
\hline Teamwork Quality (TWQ) & [141] \\
\hline Uniqueness of product benefits & [132] \\
\hline Scope of newness & [132] \\
\hline Product newness opinion as to the firm & [132] \\
\hline Product newness opinion as to the market & [132] \\
\hline Product new to the firm & [50] \\
\hline Product new to the market in what it does & [50] \\
\hline Product new to the market under technological viewpoint & [50] \\
\hline Modules new to the world & [50] \\
\hline Platform new to the world & [50] \\
\hline Essential Patent Index (EPI) & [207] \\
\hline Essential Technology Strength (ETS) & [207] \\
\hline
\end{tabular}




\section{APPENDIX $F$}

\section{CLASSIFICATION OF METRICS WITH INNOVATION ACTIVITIES}

\begin{tabular}{|c|c|}
\hline \multicolumn{2}{|l|}{ Research } \\
\hline Metrics & Source(s) \\
\hline Competitor orientation & [3] \\
\hline Inter-function coordination & [3] \\
\hline Technical orientation & [3] \\
\hline Customer orientation & [3] \\
\hline Percentage of suggestion implemented & [14] [94] \\
\hline Number of ideas that are moving from one stage of the process to the next & [14] [24] \\
\hline Number of new product ideas, product enhancement ideas evaluation in the last year & {$[94]$} \\
\hline Product planning horizon & [94] \\
\hline Number of improvement suggestions per employee & [94] \\
\hline Idea generation & [73] \\
\hline Market orientation & [147] \\
\hline Number of ideas funded & [199] \\
\hline Percentage of internal ideas offered for external license & [208] \\
\hline
\end{tabular}

\begin{tabular}{ll}
\hline \hline & \multicolumn{1}{c}{ Development } \\
\hline \multicolumn{1}{c}{ Metrics } & Source(s) \\
\hline Average concept-to-launch time & {$[14][94]$} \\
Number of products/projects in active development & {$[14][164]$} \\
Attendance at key meetings & {$[24]$} \\
Percentage of documentation submitted on deadlines & {$[24]$} \\
Percentage of projects passed on to the next stage in the process without having met all of the specified & {$[24]$} \\
requirements & {$[92]$} \\
Development process efficiency (the degree to which development process is conducted efficiently) & {$[94]$} \\
Average product life cycle length & {$[94]$} \\
Average overrun & {$[94]$} \\
Average time of product enhancement & {$[94]$} \\
Average time of redesign & {$[94]$} \\
Manufacturing cost & {$[94]$} \\
Manufacturability & {$[94]$} \\
Testability & {$[94]$} \\
R\&D/technology acquisition cost per new product & {$[94]$} \\
R\&D projects that lead to new or enhanced products, process innovation, licenses, patents & {$[73]$} \\
Optimisation tool use & {$[73]$} \\
Project efficiency & {$[209]$} \\
Frequency of adaptation & {$[209]$} \\
Rapid of adaptation & {$[209]$} \\
Ouality of adaptation & {$[210]$} \\
OOPect-Oriented Programming (OOP) Time & {$[210]$} \\
OOP Assimilation & {$[210]$} \\
Software Process Innovation (SPI) Adoption & {$[210]$} \\
SPI assimilation & {$[210]$} \\
Relational Database management system (RDB) assimilation & {$[210]$} \\
Computer-Aided Software Engineering tools (CASE) assimilation & {$[210]$} \\
\hline \hline
\end{tabular}

\begin{tabular}{ll}
\hline \hline \multicolumn{1}{c}{ Commercialization } & Metrics \\
\hline \multicolumn{1}{c}{ Source(s) } \\
\hline $\begin{array}{l}\text { Marketing effort (the level of effort invested in promotion or selling activities) } \\
\text { Market research (quality of market research effort to identify price, demand and other market }\end{array}$ & {$[92]$} \\
characteristics and firms position in the market, market stability and user needs) & {$[94]$} \\
Number of new product-based business area/ventures started in the past 5 years & {$[73]$} \\
Market research & {$[73]$} \\
Market testing & {$[73]$} \\
\hline \hline
\end{tabular}




\begin{tabular}{ll}
\hline \hline \multicolumn{1}{c}{ Metrics } & General \\
\hline \multicolumn{1}{c}{ Source(s) } \\
\hline $\begin{array}{l}\text { Innovation capability (qualitative evaluation of knowledge management, market orientation, culture, } \\
\text { innovation process, attitude towards change) }\end{array}$ & {$[3][65]$} \\
Cycle time through the entire innovation process & {$[24][116]$} \\
Cycle time through specific parts of the process (e.g., prototype or pilot run) & {$[24]$} \\
Deviation around average cycle timeshigh end to low end of the range & {$[24]$} \\
Deviation between initial expected financial value of the idea and the ultimate realised value & {$[24]$} \\
Resources expended, both per specific idea and on average & {$[24]$} \\
Resources expended on ideas that move through the process to a particular point but then are not & {$[24]$} \\
ultimately commercialised & {$[25]$} \\
Cash payback & {$[94]$} \\
Managers survey & {$[43]$} \\
Time for each phase & {$[43]$} \\
Mean number of adoption overtime & {$[43]$} \\
Mean time of adoption overtime & {$[116]$} \\
Consistency of the time of innovation adoption & \\
Success ratio at different process gates & \\
\hline \hline
\end{tabular}




\section{APPENDIX G}

CLASSIFICATION OF METRICS FOR EVALUATION OF INNOVATION OUTPUT AND PERFORMANCE

\begin{tabular}{ll}
\hline \hline \multicolumn{1}{c}{ Product-related metrics } & Source(s) \\
\hline The perceived effectiveness of innovation & {$[6][13][24][94][59][79]$} \\
Patent count per time period / patent density & {$[6][123][165][169][176]$} \\
& {$[177][179][211][212]$} \\
& {$[13]$} \\
Whether or not a firm had accomplished at least one major product innovation during the 3 years & {$[13]$} \\
preceding the survey & {$[14][213]$} \\
Product innovation index & {$[24]$} \\
New products or services & {$[25][214]$} \\
Number of books and papers published & {$[215]$} \\
Intellectual property counts & {$[25][79][103]$} \\
Patent citations & {$[50]$} \\
New product launches & {$[50]$} \\
Product new to the firm & {$[50]$} \\
Product new to the market in what it does & {$[50]$} \\
Product new to the market under technological viewpoint & {$[50]$} \\
Modules new to the world & {$[56][77][60][103]$} \\
Platform new to the world & {$[132]$} \\
Number of innovation & {$[132]$} \\
Uniqueness of product benefits & {$[132]$} \\
Scope of newness & {$[132]$} \\
Product newness opinion as to the firm & {$[169]$} \\
Product newness opinion as to the market & {$[98]$} \\
Volume of high-technology exports (relative to the total manufactured exports) & {$[98]$} \\
Products new to the world, developed using new or significantly improved technology & {$[98]$} \\
Products new to the nation, developed using new or significantly improved technology & {$[208]$} \\
Products new to the firm, developed using new or significantly improved technology & \\
Number of projects terminated last year, reviewed at a later date, offered to external parties for further \\
development
\end{tabular}

\begin{tabular}{ll}
\hline \hline \multicolumn{1}{c}{ Market-related metrics } & Source(s) \\
\hline $\begin{array}{l}\text { Number of strategic options (i.e. newly created opportunities to significantly advance an existing } \\
\text { business) }\end{array}$ & {$[14]$} \\
New market application of existing products or services & {$[213]$} \\
\hline \hline
\end{tabular}

\begin{tabular}{|c|c|}
\hline Organisation-related metrics & Source(s) \\
\hline New organisational programs & [213] \\
\hline New organisational structures & [213] \\
\hline
\end{tabular}

\begin{tabular}{|c|c|}
\hline Process-related metrics & Source(s) \\
\hline Number of new processes and significant enhancements per year & [94] \\
\hline Average annual improvement in process parameters & [94] \\
\hline Process innovation 1 & [56] \\
\hline Activities new to the world, developed using new or significantly improved technology & [98] \\
\hline Activities new to the nation, developed using new or significantly improved technology & [98] \\
\hline Activities new to the firm, developed using new or significantly improved technology & [98] \\
\hline New processes (technologies) & [213] \\
\hline
\end{tabular}




\begin{tabular}{|c|c|}
\hline Performance-related metrics & Source(s) \\
\hline Percentage of sales that is generated by new products & $\begin{array}{l}{[3][14][24][26][117]} \\
{[147][164]}\end{array}$ \\
\hline $\begin{array}{l}\text { Number of new competencies (i.e. distinctive skills and knowledge domains that spawn innovation) } \\
\text { measured as a simple count among a threshold proportion of employees }\end{array}$ & {$[14]$} \\
\hline Number of new markets entered in past year & [14] \\
\hline $\begin{array}{l}\text { Share of wealth, i.e., the change in the companys market value during the past year divided by the } \\
\text { change in the total industrys market value during the same period }\end{array}$ & [14] \\
\hline $\begin{array}{l}\text { Organisational innovation (product of coefficient of innovativeness tendency and success of product } \\
\text { innovation) }\end{array}$ & {$[15]$} \\
\hline Brand innovation quotient & [19] \\
\hline Innovation loyalty (ratio of repeat purchasers to total number of purchasers) & [19] \\
\hline Return on investment or project net present value & [19] [199] \\
\hline Overall revenue growth & [24] \\
\hline Third-party rankings or cross-company benchmarking & [24] \\
\hline Revenue from new platforms & [26] \\
\hline Customer satisfaction & [94] \\
\hline Product quality & [94] \\
\hline Number of pages in the annual report devoted to innovation and technology & [94] \\
\hline Throughput & [65] \\
\hline Impact on brand & [116] \\
\hline Innovation performance & [125] \\
\hline Share of sales from product imitations & [103] [191] \\
\hline Innovation intensities & {$[104]$} \\
\hline Innovation index & [131] \\
\hline Total patents filed/pending/awarded & [164] \\
\hline Innovation capacity & [167] \\
\hline Citations & [177] \\
\hline Citation ratio & [177] \\
\hline Average number of patents per capita & [179] \\
\hline Share of sales from market novelties & [191] \\
\hline Cost reductions due to process innovations & [191] \\
\hline Long-term customer adoption & [199] \\
\hline Percentage of sales of products and services came from externally licensed technologies & [208] \\
\hline Percentage of net income last year came from technology licensed out to other companies & [208] \\
\hline Patent-intensity (measured by successful patent applications per million dollars of total assets) & [216] \\
\hline Essential Patent Index (EPI) & [207] \\
\hline Essential Technology Strength ETS & [207] \\
\hline
\end{tabular}




\section{APPENDIX H}

\section{Classification OF METRICS FOR EVALUATION OF INNOVATION INPUTS}

\begin{tabular}{|c|c|}
\hline Inputs & Metrics \\
\hline $\begin{array}{l}\text { Staffing, labour, people, technical personnel [14] [24] [116] [131] } \\
\text { [214] [217] }\end{array}$ & $\begin{array}{l}\text { The number of ideas, with expected payback potential for each } \\
\text { [24] }\end{array}$ \\
\hline Capital [14] [24] [116] & $\begin{array}{l}\text { Science and technology availability (the degree to which science } \\
\text { and technology needed for the project is readily available) [92] }\end{array}$ \\
\hline Operating expenditures [116] & $\begin{array}{l}\text { Firm technical capability (the adequacy of the firms technical } \\
\text { capability to support the projects complexity) [92] }\end{array}$ \\
\hline Time [14] & Facilities or physical resources [73] \\
\hline Technology licensing [120] & Tools for support of innovation [73] \\
\hline R\&D [120] [144] [168] & $\begin{array}{l}\text { Percentage of employees for whom innovation is a key perfor- } \\
\text { mance goal [14] }\end{array}$ \\
\hline R\&D personnel [218] & $\begin{array}{l}\text { R\&D intensity (ratio of R\&D expenditure to total assets) [94] } \\
\text { [216] }\end{array}$ \\
\hline R\&D activities [167] & Human capital [211] \\
\hline R\&D effort [117] & $\begin{array}{l}\text { The number of full-time equivalent staff for selected functions } \\
\text { involved in the processand, most importantly, what their key } \\
\text { people are working on) [59] [24] [73] }\end{array}$ \\
\hline R\&D expenditure [131] [203] [214] [216] [217] & Number of foreign companies [211] \\
\hline Knowledge spill-overs [191] & The operating expense [24] \\
\hline Access to complementary knowledge [191] & The capital expenditure [24] \\
\hline Cost and risk-sharing in innovation projects [218] & Staffing and capital and operating expenditure [116] \\
\hline Information and knowledge [135] & R\&D expenditure [59] [211] \\
\hline $\begin{array}{l}\text { Technology transfer and networking as alternative input to R\&D } \\
\text { [137] }\end{array}$ & Total R\&D head count $[164]$ \\
\hline \multirow[t]{6}{*}{ Training [120] } & R\&D spending (as percent of sales) [164] \\
\hline & $\begin{array}{l}\text { Percentage of employees who have received training in innova- } \\
\text { tion for example, instruction in estimating market potential of } \\
\text { an idea [14] }\end{array}$ \\
\hline & $\begin{array}{l}\text { Number of innovation tools and methodologies available to } \\
\text { employees [14] }\end{array}$ \\
\hline & $\begin{array}{l}\text { Percentage of capital that is invested in innovation activities } \\
\text { such as submitting and reviewing ideas for new products and } \\
\text { services and developing ideas through an innovation pipeline } \\
\text { [14] }\end{array}$ \\
\hline & $\begin{array}{l}\text { Number of entrepreneurs in the company, i.e. individuals who } \\
\text { have previously started a business, either within the company } \\
\text { or before joining the company [14] }\end{array}$ \\
\hline & $\begin{array}{l}\text { Percentage of workforce time that is currently dedicated to } \\
\text { innovation projects [14] }\end{array}$ \\
\hline
\end{tabular}




\section{APPENDIX I}

\section{INNOVATION MEASUREMENT FRAMEWORKS FOUND IN LITERATURE}

\begin{tabular}{|c|c|c|c|c|c|}
\hline Source & Name of framework & $\begin{array}{l}\text { Research } \\
\text { methodology }\end{array}$ & Purpose & $\begin{array}{l}\text { Means of repre- } \\
\text { sentation }\end{array}$ & Validation \\
\hline $\begin{array}{l}\text { Muller et } \\
\text { al.[14] }\end{array}$ & $\begin{array}{l}\text { Guidelines for develop- } \\
\text { ing a customised suite } \\
\text { of innovation metrics }\end{array}$ & $\begin{array}{l}\text { Conceptual } \\
\text { analysis }\end{array}$ & Framework for the selection of metrics & Table & $\begin{array}{l}\text { No valida- } \\
\text { tion }\end{array}$ \\
\hline $\begin{array}{l}\text { Kumar et } \\
\text { al. [92] }\end{array}$ & Monitoring framework & Survey & $\begin{array}{l}\text { Assist managers in deciding whether to } \\
\text { abandon an ongoing } R \& D / \text { innovation } \\
\text { project at various stages of } R \& D\end{array}$ & $\begin{array}{l}\text { Mathematical } \\
\text { formula }\end{array}$ & $\begin{array}{l}\text { No valida- } \\
\text { tion }\end{array}$ \\
\hline $\begin{array}{l}\text { Aiman- } \\
\text { Smith et al. } \\
\text { [64] }\end{array}$ & $\begin{array}{l}\text { Value Innovation Po- } \\
\text { tential Assessment Tool }\end{array}$ & $\begin{array}{l}\text { Conceptual } \\
\text { analysis }\end{array}$ & $\begin{array}{l}\text { Measuring important factors leading to } \\
\text { value innovation }\end{array}$ & Table & $\begin{array}{l}\text { No valida- } \\
\text { tion }\end{array}$ \\
\hline $\begin{array}{l}\text { Capaldo et } \\
\text { al. [93] }\end{array}$ & $\begin{array}{l}\text { Innovation capabilities } \\
\text { evaluation model }\end{array}$ & Case studies & $\begin{array}{l}\text { An evaluation model for the determina- } \\
\text { tion of small firms innovation capabili- } \\
\text { ties (based on Chiesa framework [94]) }\end{array}$ & $\begin{array}{l}\text { Mathematical } \\
\text { formula }\end{array}$ & $\begin{array}{l}\text { No valida- } \\
\text { tion }\end{array}$ \\
\hline $\begin{array}{l}\text { Chiesa et al. } \\
\text { [94] }\end{array}$ & Technical audit & Experiment & $\begin{array}{l}\text { diting technical inno- } \\
\text { tt }\end{array}$ & $\begin{array}{l}\text { Table } \\
\text { (Scorecard) }\end{array}$ & $\begin{array}{l}\text { Static vali- } \\
\text { dation }\end{array}$ \\
\hline $\begin{array}{l}\text { Cormican } \\
{[47]}\end{array}$ & PIM Scorecard & Case studies & $\begin{array}{l}\text { Assess whether the conditions neces- } \\
\text { sary for innovation are in place and the } \\
\text { degree to which best practice is used }\end{array}$ & $\begin{array}{l}\text { Table } \\
\text { (Scorecard) }\end{array}$ & $\begin{array}{l}\text { No valida- } \\
\text { tion }\end{array}$ \\
\hline Tang [134] & $\begin{array}{l}\text { Inventory of organisa- } \\
\text { tional innovativeness }\end{array}$ & Survey & $\begin{array}{l}\text { Measure organisational effectiveness in } \\
\text { innovation }\end{array}$ & Table & $\begin{array}{l}\text { No valida- } \\
\text { tion }\end{array}$ \\
\hline $\begin{array}{l}\text { Byrne et al. } \\
{[100]}\end{array}$ & $\begin{array}{l}\text { A lean six sigma ap- } \\
\text { proach }\end{array}$ & Industry report & $\begin{array}{l}\text { Measure preparedness of an organisa- } \\
\text { tion to undertake radical innovations }\end{array}$ & Diagram & $\begin{array}{l}\text { Industrial } \\
\text { usage }\end{array}$ \\
\hline $\begin{array}{l}\text { Furman et } \\
\text { al. [95] }\end{array}$ & $\begin{array}{l}\text { National innovation ca- } \\
\text { pacity }\end{array}$ & $\begin{array}{l}\text { Conceptual } \\
\text { analysis }\end{array}$ & $\begin{array}{l}\text { Measure the ability of a country to } \\
\text { produce and commercialisation a flow } \\
\text { of innovative technology over the long } \\
\text { term }\end{array}$ & Graph & $\begin{array}{l}\text { No valida- } \\
\text { tion }\end{array}$ \\
\hline Nirjar [98] & Index of innovativeness & Survey & $\begin{array}{l}\text { Indicates the stages of firms growth vis- } \\
\text {-vis its innovation capability }\end{array}$ & $\begin{array}{l}\text { Mathematical } \\
\text { formula }\end{array}$ & $\begin{array}{l}\text { No valida- } \\
\text { tion }\end{array}$ \\
\hline $\begin{array}{l}\text { Maravelakis } \\
\text { et al. [99] }\end{array}$ & $\begin{array}{l}\text { Product Innovation } \\
\text { Process (PIP) Score }\end{array}$ & $\begin{array}{l}\text { Conceptual } \\
\text { analysis }\end{array}$ & $\begin{array}{l}\text { Assessing innovation and determining } \\
\text { a product innovation profile }\end{array}$ & 3-D graph & $\begin{array}{l}\text { No valida- } \\
\text { tion }\end{array}$ \\
\hline $\begin{array}{l}\text { Wang et al. } \\
\text { [96] }\end{array}$ & $\begin{array}{l}\text { Technological } \\
\text { innovation capability } \\
\text { evaluation }\end{array}$ & $\begin{array}{l}\text { Conceptual } \\
\text { analysis }\end{array}$ & $\begin{array}{l}\text { Method to assess the technical innova- } \\
\text { tion capability of a firm }\end{array}$ & $\begin{array}{l}\text { Mathematical } \\
\text { formula }\end{array}$ & $\begin{array}{l}\text { No valida- } \\
\text { tion }\end{array}$ \\
\hline $\begin{array}{l}\text { Yam et al. } \\
\text { [97] }\end{array}$ & Audit criteria & Survey & $\begin{array}{l}\text { Examine the technological capabilities } \\
\text { of Chinese firms }\end{array}$ & Table & $\begin{array}{l}\text { No valida- } \\
\text { tion }\end{array}$ \\
\hline
\end{tabular}




\section{APPENDIX J}

STUDIES FOUND IN SYSTEMATIC REVIEW RELATED TO SOFTWARE

\begin{tabular}{|c|c|c|c|c|}
\hline & Title & Author(s) & $\begin{array}{l}\text { Publication } \\
\text { year }\end{array}$ & Journal \\
\hline [3] & $\begin{array}{l}\text { Innovative capability, innovation strategy and market orienta- } \\
\text { tion: An empirical analysis in Turkish software industry }\end{array}$ & $\begin{array}{l}\text { G. Akman and } \\
\text { C. Yilmaz }\end{array}$ & 2008 & $\begin{array}{l}\text { International Journal of In- } \\
\text { novation Management }\end{array}$ \\
\hline [13] & $\begin{array}{l}\text { Determinants of innovation capability in small electronics and } \\
\text { software firms in southeast England }\end{array}$ & $\begin{array}{l}\text { H. Romijn, M. } \\
\text { Albaladejo }\end{array}$ & 2002 & Research Policy \\
\hline [50] & $\begin{array}{l}\text { Software innovativeness. A comparison between proprietary } \\
\text { and Free/Open Source solutions offered by Italian SMEs }\end{array}$ & C. R. Lamastra & 2009 & $\mathrm{R}$ and $\mathrm{D}$ Management \\
\hline [54] & $\begin{array}{l}\text { Transformational leadership and organizational innovation: } \\
\text { The roles of internal and external support for innovation }\end{array}$ & $\begin{array}{l}\text { L. Gumuslulu } \\
\text { and A. Ilsev }\end{array}$ & 2009 & $\begin{array}{l}\text { Journal of Product Innova- } \\
\text { tion Management }\end{array}$ \\
\hline [93] & $\begin{array}{l}\text { The Evaluation of Innovation Capabilities in Small Software } \\
\text { Firms: A Methodological Approach }\end{array}$ & $\begin{array}{l}\text { G. Capaldo, I. } \\
\text { Iandoli }\end{array}$ & 2003 & Small Business Economics \\
\hline [132] & $\begin{array}{l}\text { Software innovativeness: Outcomes on project performance, } \\
\text { knowledge enhancement, and external linkages }\end{array}$ & $\begin{array}{l}\text { G. Jordan and } \\
\text { E. Segelod }\end{array}$ & 2006 & $\mathrm{R}$ and $\mathrm{D}$ Management \\
\hline [139] & $\begin{array}{l}\text { Organizational determinants of innovation capacity in soft- } \\
\text { ware companies }\end{array}$ & T. Koc & 2007 & $\begin{array}{l}\text { Computers \& Industrial En- } \\
\text { gineering }\end{array}$ \\
\hline [141] & $\begin{array}{l}\text { Teamwork Quality and the Success of Innovative Projects: A } \\
\text { Theoretical Concept and Empirical Evidence }\end{array}$ & $\begin{array}{l}\text { M. Hoegl \& H. } \\
\text { G. Gemuenden }\end{array}$ & 2001 & Organization Science \\
\hline [89] & $\begin{array}{l}\text { Determinants of success in the development of applications } \\
\text { software }\end{array}$ & C. A. Voss & 1985 & $\begin{array}{l}\text { Journal of Product Innova- } \\
\text { tion Management }\end{array}$ \\
\hline [147] & $\begin{array}{l}\text { An Empirical Investigation of the Effect of Market Orienta- } \\
\text { tion and Entrepreneurship Orientation Alignment on Product } \\
\text { Innovation }\end{array}$ & $\begin{array}{l}\text { K. Atuahene- } \\
\text { Gima and A. } \\
\text { Ko }\end{array}$ & 2001 & Organization Science \\
\hline [160] & $\begin{array}{l}\text { Transformation of science and technology systems into sys- } \\
\text { tems of innovation in central and eastern Europe: the emerging } \\
\text { patterns and determinants }\end{array}$ & S. Radosevic & 1999 & $\begin{array}{l}\text { Structural Change and Eco- } \\
\text { nomic Dynamics }\end{array}$ \\
\hline [88] & $\begin{array}{l}\text { Investigating the Drivers of Innovation and New Product } \\
\text { Success: A Comparison of Strategic Orientations }\end{array}$ & A. Paladino & 2007 & $\begin{array}{l}\text { Journal of Product Innova- } \\
\text { tion Management }\end{array}$ \\
\hline [162] & $\begin{array}{l}\text { Explaining innovative activity in service industries: Micro data } \\
\text { evidence for Switzerland }\end{array}$ & S. Arvanitis & 2008 & $\begin{array}{l}\text { Economics of Innovation } \\
\text { and New Technology }\end{array}$ \\
\hline [183] & $\begin{array}{l}\text { Governance structures and innovation in the Irish Software } \\
\text { Industry }\end{array}$ & $\begin{array}{l}\text { C. A. Fitzger- } \\
\text { ald, P. C. Flood, } \\
\text { P. O'Regan, N. } \\
\text { Ramamoorthy }\end{array}$ & 2008 & $\begin{array}{l}\text { Journal of High Technology } \\
\text { Management Research }\end{array}$ \\
\hline [91] & $\begin{array}{l}\text { The influence of creative style and climate on software devel- } \\
\text { opment team creativity: an exploratory study }\end{array}$ & M. H. Fagan & 2004 & $\begin{array}{l}\text { Journal of Computer Infor- } \\
\text { mation Systems }\end{array}$ \\
\hline [98] & $\begin{array}{l}\text { Innovations and Evolution of Software SMEs: Exploring the } \\
\text { Trajectories for Sustainable Growth }\end{array}$ & A. Nirjar & 2008 & Vision \\
\hline [207] & $\begin{array}{l}\text { Using Essential Patent Index and Essential Technological } \\
\text { Strength to evaluate industrial technological innovation com- } \\
\text { petitiveness }\end{array}$ & D. Z. Chen & 2007 & Scientometrics \\
\hline [219] & KISA in innovation of New Zealand software firms & J. Williams & 2006 & $\begin{array}{l}\text { International Journal of Ser- } \\
\text { vices Technology and Man- } \\
\text { agement }\end{array}$ \\
\hline [220] & $\begin{array}{l}\text { Definition of innovation revisited:: an empirical study on } \\
\text { Indian information technology industry }\end{array}$ & $\begin{array}{l}\text { S. Goswami, M. } \\
\text { Matthew }\end{array}$ & 2005 & $\begin{array}{l}\text { International Journal of In- } \\
\text { novation Management }\end{array}$ \\
\hline [221] & $\begin{array}{l}\text { Software engineering technology innovation - Turning re- } \\
\text { search results into industrial success }\end{array}$ & $\begin{array}{l}\text { T. R. Punter, L. } \\
\text { Krikhaar }\end{array}$ & 2009 & $\begin{array}{l}\text { Journal of System and Soft- } \\
\text { ware }\end{array}$ \\
\hline [222] & $\begin{array}{l}\text { Assessing the management of innovation with software tools: } \\
\text { An application of innovation Enterpriser }\end{array}$ & S. J. Conn & 2009 & $\begin{array}{l}\text { International Journal of } \\
\text { Technology Management }\end{array}$ \\
\hline [223] & $\begin{array}{l}\text { Software process innovation methodology - Multiple approach } \\
\text { including ISO9001, maturity model and QC technique }\end{array}$ & K. Honda & 1997 & $\begin{array}{l}\text { NEC Research and Devel- } \\
\text { opment }\end{array}$ \\
\hline [210] & $\begin{array}{l}\text { The role of aggregation in the measurement of IT-related } \\
\text { organizational innovation }\end{array}$ & $\begin{array}{l}\text { Robert G. Fich- } \\
\text { man }\end{array}$ & 2001 & MIS Quarterly \\
\hline
\end{tabular}




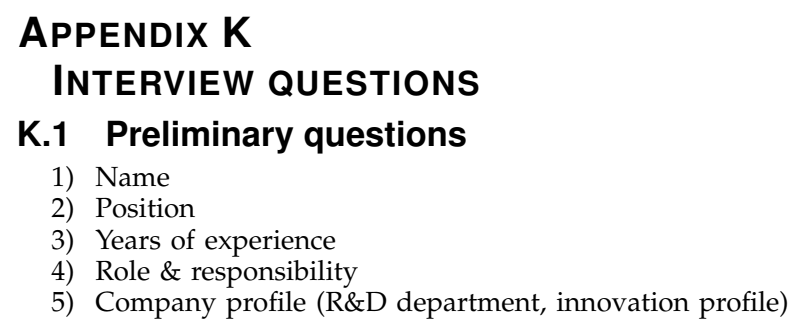

\section{K.2 General questions}

\section{K.2.1 Perception about innovation}

1) What do you mean by innovation?

2) What is considered as innovation? (Type of innovation) \& for company

3) Is innovation considered a strategic objective of the company? (Importance of innovation)

4) Does your organisation have a formal innovation process? What are the major phases of this process (activities in the process)?

5) What is the role of R\&D in innovation?

6) What aspects of innovation are considered important and measurable?

\section{K.2.2 Innovation measurement}

1) Do you measure innovation?

2) If yes, how do you measure innovation? What metrics or measurements are used for this purpose?

3) If the answer is no, why is innovation not measured?

4) Are you satisfied with the control and visibility these metrics give you for management of innovation program?

5) What are the major issues in measuring innovation? (definition, lack of metrics)

6) Does your organisation have a specific framework or methodology to measure innovation?

7) f yes, could you describe the major steps?

8) If no, what are the reasons and how do you perform the measurement process?

9) What measures the organisation takes to protect its Intellectual Property? (e.g. patents, non disclosure agreements, copyrights)

10) In your context, what are the most valuable inputs/pressing challenges/barrier for (measuring) innovation?

11) What metrics do you collect?

\section{K.3 Findings review}

After the initial questions we presented the major findings and the model of innovation that we have developed from the systematic literature review. Get their comments and feedback about the results.

1) Do you think there is an aspect of innovation that is missing in this model?

2) What do you think we can add to this model to make it usable for industry? 


\section{APPENDIX L}

\section{BACKGROUND INFORMATION OF INTERVIEWEES}

\begin{tabular}{|c|c|c|c|c|c|}
\hline Interviewee I & & Experience & Firm ID & Firm size & Role \& responsibilities \\
\hline $\begin{array}{l}\text { Interviewee } \\
\text { [INT_A] }\end{array}$ & $\mathrm{A}$ & $\begin{array}{l}>30 \text { years of industrial ex- } \\
\text { perience }\end{array}$ & Firm A & Large & $\begin{array}{l}\text { She has worked as R\&D manager in an electrical and manufac- } \\
\text { turing firm. Currently she is product line manager for application } \\
\text { software at a large multinational firm. Her responsibilities include } \\
\text { supervision, management and development of the area of application } \\
\text { software in the organization. }\end{array}$ \\
\hline $\begin{array}{l}\text { Interviewee } \\
\text { [INT_B] }\end{array}$ & $\mathrm{B}$ & $\begin{array}{l}>18 \text { years of industrial ex- } \\
\text { perience }\end{array}$ & Firm A & Large & $\begin{array}{l}\text { R\&D Manager, responsible for requirements management, feasibility } \\
\text { studies, estimations and subsequent development. }\end{array}$ \\
\hline $\begin{array}{l}\text { Interviewee } \\
\text { [INT_C] }\end{array}$ & C & $\begin{array}{l}>20 \text { years of academic ex- } \\
\text { perience. }\end{array}$ & Firm B & Small & $\begin{array}{l}\text { She has extensive teaching experience in areas such as strategy, } \\
\text { innovation and business development. Currently she is heading an } \\
\text { initiative to promote innovation through a nursery to stimulate and } \\
\text { develop practical innovations. }\end{array}$ \\
\hline $\begin{array}{l}\text { Interviewee } \\
\text { [INT_D] }\end{array}$ & $\mathrm{D}$ & $\begin{array}{l}>10 \text { years of industrial ex- } \\
\text { perience and }>\text { four years of } \\
\text { academic experience }\end{array}$ & Firm $\mathrm{C}$ & $\begin{array}{l}\text { Both SME } \\
\text { and large } \\
\text { firms }\end{array}$ & $\begin{array}{l}\text { She has worked as industrial consultant, project manager, and exec- } \\
\text { utive roles for different firms. She has also led many startups and is } \\
\text { currently involved with industrial research. }\end{array}$ \\
\hline $\begin{array}{l}\text { Interviewee } \\
\text { [INT_E] }\end{array}$ & $\mathrm{E}$ & $\begin{array}{l}>10 \text { years of action research } \\
\text { in industry }\end{array}$ & Firm D & $\begin{array}{l}\text { Not } \\
\text { applicable }\end{array}$ & $\begin{array}{l}\text { She is an associate professor and is mostly involved in action research } \\
\text { in the industry. Her interests include usability studies and human } \\
\text { interaction and measurement thereof. }\end{array}$ \\
\hline $\begin{array}{l}\text { Interviewee } \\
\text { [INT_F] }\end{array}$ & $\mathrm{F}$ & $\begin{array}{l}>22 \text { years of industrial ex- } \\
\text { perience }\end{array}$ & Firm $E$ & Large & $\begin{array}{l}\text { She is working as a general manager in a telecommunication firm. } \\
\text { She is heading the group responsible for external collaboration and } \\
\text { asset management in the company. }\end{array}$ \\
\hline $\begin{array}{l}\text { Interviewee } \\
\text { [INT_G] }\end{array}$ & G & $\begin{array}{l}>12 \text { years of industrial ex- } \\
\text { perience }\end{array}$ & Firm E & Large & $\begin{array}{l}\text { She is director of strategy at a prominent telecommunication firm. } \\
\text { She has a technical background and is especially interested in how } \\
\text { innovations affect society and human mind. Her analysis of future } \\
\text { trends helps decide the future direction for the company. }\end{array}$ \\
\hline
\end{tabular}




\section{APPENDIX M}

QUESTIONNAIRE QUESTIONS

\section{Innovation measurement in software industry}

\section{Introduction}

We are masters students in software engineering at Blekinge Institute of Technology, Sweden. In our master's thesis, we are working on innovation measurement to assess the capacity and performance of software firms in terms of innovation. In this regard, we would like to get feedback from software industry practitioners on what they perceive as innovation and how they currently measure innovation.

We would like you to fill out this short survey (approx. five minutes) to give us your insight and experience about innovation measurement practices in your organization.

The demographic information acquired here will be kept confidential and will only be used for statistical purposes in this thesis project.

\section{* 1. Please fill out the required demographic information below:}

\section{position:}

Jeb experience (in

years):

Company:

Number of empleyees

Country:

\section{Email Address ( if you are interested in the results of this survey )}

\section{Definition}

For question 3, 4 and 5 you may choose more than one option in the answer.

\section{* 3. In your opinion, innovation involves:}

Generation of adoption of new ideas.

Development of new products, processes, methods or techniques.

Improvement in existing products, processes, methods or techniques.

Introduction of products to the market, use of processes and methods in the organization.

other (please specify)

|rit 


\section{Innovation measurement in software industry}

\section{* 4. In your opinion which of the following may be considered as} innovation?

$\square$ Introduction of a good or service that is new with respect to its characteristics or intended uses.

$\square$ Implementation of a new design, analysis or develepment method.

Implementation of a new marketing method in product design or packaping, product placemenk, product premotion or pricing.

Implementation of a new organisational method in the firm's business practices, workplace orgarisation or external relations.

$\square$ other (please specify)

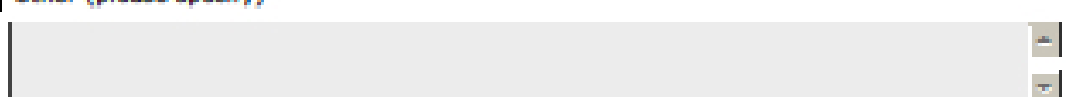

\section{* 5. To be considered as innovation it must be:}

New to the world

$\square$ New to the industry

$\square$ New to the market

$\square$ New to the firm

\section{Innovation measurement 1}

Innovation measurement is the assessment of organizations innovation output and capacity to innovate.

For example by measuring availability of resources like funds and human capital, creative environment, policy, customer orientation and by innovation process benchmarking etc.

* 6. Do you think innovation measurement is important for your organization?
Yres
No
I de not know.

Mease describe the reason for your answer briefly.

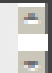

* 7. Does your organization have an explicit strategy on innovation?

Yes

No

I do not know 
Innovation measurement in software industry

* 8. Does your organization measure innovation?

Ores

No

OI do not know

Mease briefly explain the reason for your ansmer.

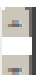

* 9. Which of the following do you think are the main challenges for innovation measurement in your organization?

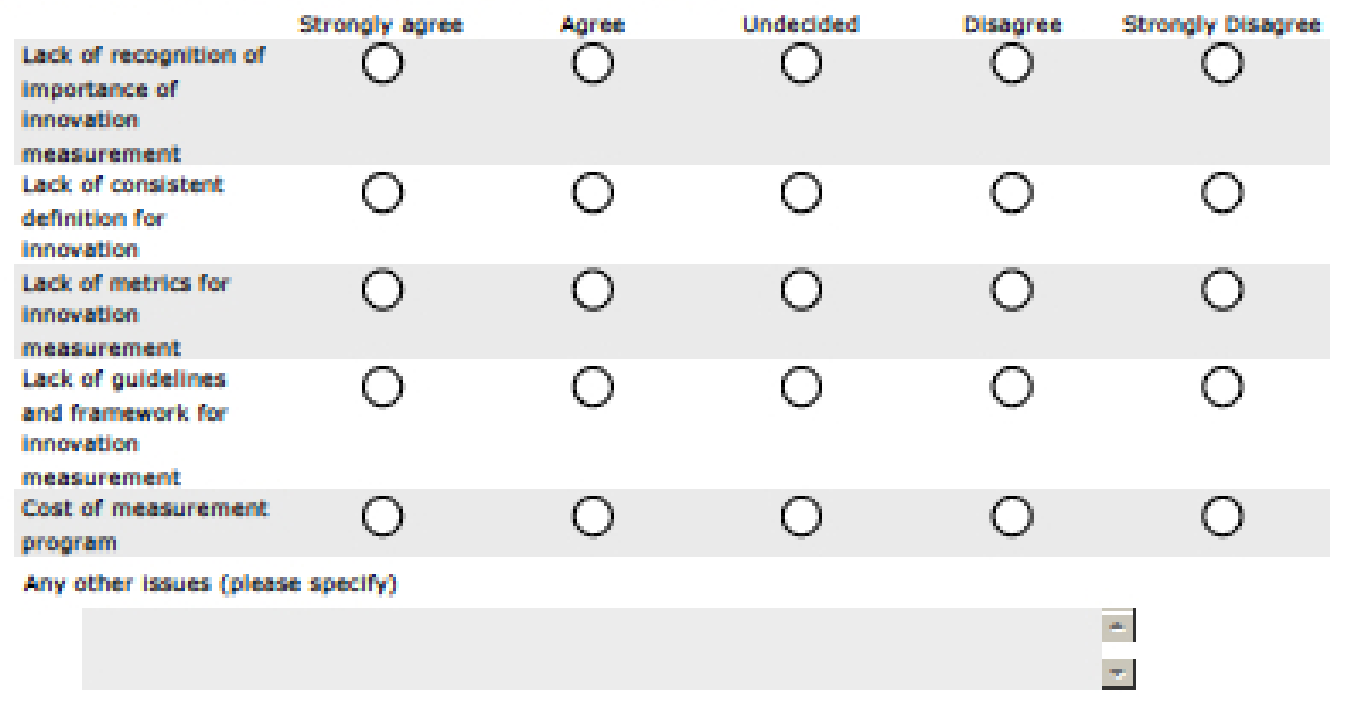

Input to Innovation 


\section{Innovation measurement in software industry}

* 10. Which of the following innovation metrics are collected in your organization?

$\square$ Percentage of sales spent on PBD

$\square$ Percentage of sales spent on new projects

$\square$ Percentage of employees dedicated to kSO activities

Number of new ideas generated

$\square$ Number of ldeas comerted successfully to products

$\square$ Time taken in converting an idea to a product or process

$\square$ Number of new products

Number of improvements in existing products (e-g. ntew or impreved features, architectural changes or performance improvements etc)

$\square$ Number of intellectual property rights (e. 9 . patents, papers published, trademarks)

$\square$ Creative Environement (using subjective measures)

Presence of Innevation Champlens ( Individuals with political skills, contacts and reputation required to secure resources and who actively and enthusiastically promote innovation progress through critical stages )

$\square$ Percentage of new product sales to total sales

$\square$ Improvement in product quality as a result of innevation

Improvement of custemer satisfaction as a result of innovation

Other (please specily)

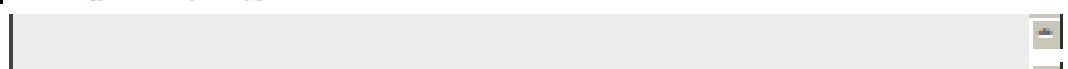

* 11. Do these metrics give you enough control and visibility to successfully manage innovation program?

$\bigcirc$ Yes

No, please describe why

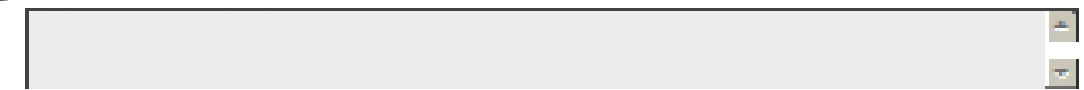

* 12. Does your organization use any framework or methodology to measure innovation?

No

Yes, please describe the major steps involved in the measurement process 